University of Louisville

ThinkIR: The University of Louisville's Institutional Repository

Electronic Theses and Dissertations

8-2012

\title{
Teenagers' safety at work : dangerous tasks and safety training.
}

Teresa Jane McGeeney 1987-

University of Louisville

Follow this and additional works at: https://ir.library.louisville.edu/etd

\section{Recommended Citation}

McGeeney, Teresa Jane 1987-, "Teenagers' safety at work : dangerous tasks and safety training." (2012). Electronic Theses and Dissertations. Paper 948.

https://doi.org/10.18297/etd/948

This Master's Thesis is brought to you for free and open access by ThinkIR: The University of Louisville's Institutional Repository. It has been accepted for inclusion in Electronic Theses and Dissertations by an authorized administrator of ThinkIR: The University of Louisville's Institutional Repository. This title appears here courtesy of the author, who has retained all other copyrights. For more information, please contact thinkir@louisville.edu. 


\title{
TEENAGERS' SAFETY AT WORK:
}

\section{DANGEROUS TASKS AND SAFETY TRAINING}

\author{
By \\ Teresa Jane McGeeney \\ B.A., University of Notre Dame, 2010
}

\begin{abstract}
A Thesis
Submitted to the Faculty of the

School of Public Health and Information Sciences in Partial Fulfillment of the Requirements for the Degree of

Master of Science

Department of Epidemiology and Population Health University of Louisville Louisville, Kentucky
\end{abstract}

August 2012 
Copyright 2012 by Teresa Jane McGeeney

All rights reserved 
TEENAGERS' SAFETY AT WORK:

DANGEROUS TASKS AND SAFETY TRAINING

\author{
By \\ Teresa Jane McGeeney \\ B.A., University of Notre Dame, 2010 \\ July 25, 2012 \\ by the following Thesis Committee:
}

Kristina M. Zierold

Thesis Director

Kathy B. Baumgartner

Guy Brock 


\section{ACKNOWLEDGEMENTS}

The data presented in this thesis are from a study funded by the Centers for Disease Control and Prevention/National Institute for Occupational Safety and Health, grant R21OH008934 - Evaluation Of Safety Training, Supervision, and Injury Among Working Teenagers.

I would like to give a special thank you to my thesis advisor, Dr. Kris Zierold, for all of her help and guidance through this process. I would also like to thank my other committee members, Dr. Guy Brock and Dr. Kathy Baumgartner, for all of their assistance.

My thesis would not be accomplished had it not been for the incredible support I received from my family and friends: my mother and father, who have blessed with me

invaluable educational opportunities, Catherine, Trevor, Daniel, Sarah, Ross, and Gloria, who have all lent their support in countless ways. Thank you for your patience, your encouragement, your advice, and your faith in me. 


\section{ABSTRACT \\ TEENAGERS' SAFETY AT WORK: \\ DANGEROUS TASKS AND SAFETY TRAINING \\ Teresa J. McGeeney}

July 25,2012

Teenaged workers are twice as likely to be injured on the job as adult workers, and face a number of differences developmentally and psychosocially that present challenges for their safety at work. Little research has focused on the tasks that teenagers perform at work and what factors mediate their performance of hazardous tasks and tasks prohibited by law. Data used for this thesis was collected through a survey of 884 teenagers enrolled at two public high schools in Louisville, Kentucky in Spring 2011. Focus groups and interviews were also conducted with 42 employed teenagers in Spring 2010 to provide qualitative data. Demographic, behavioral, and work-related factors associated with performing of tasks that are hazardous or prohibited are discussed. Additionally, the impacts of safety training methods, lessons, and length on performance of these tasks are examined. Important findings include new insights into the role of race in teens' safety at work as well as the novel finding that longer safety training is associated with lower proportions of teens performing hazardous and dangerous tasks. Implications of the results are discussed. 


\section{TABLE OF CONTENTS}

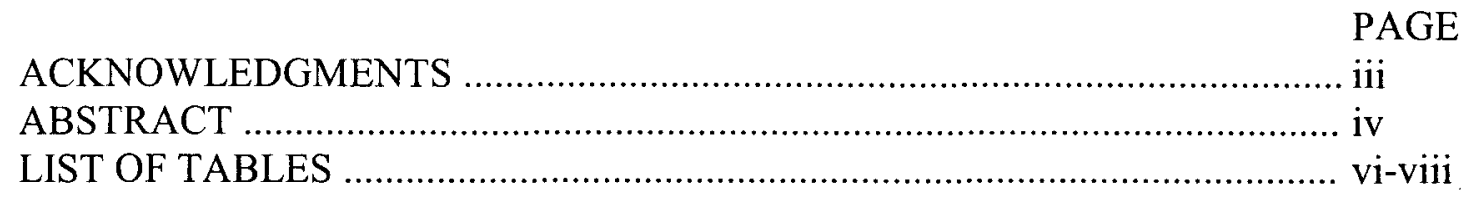

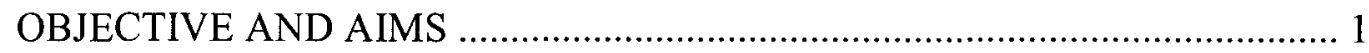

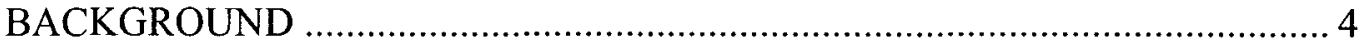

Work-related Injury among Youth ............................................................... 4

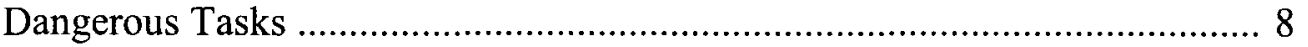

Protection against Work-related Injury ....................................................... 15

Summary and Justification for Research ..................................................... 16

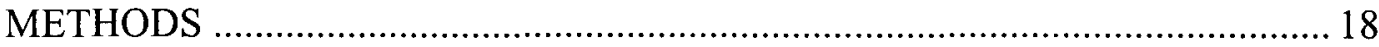

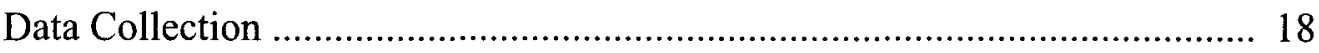

Data Input and Quality Control Measures .................................................. 21

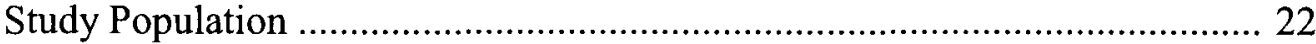

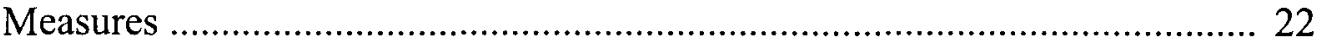

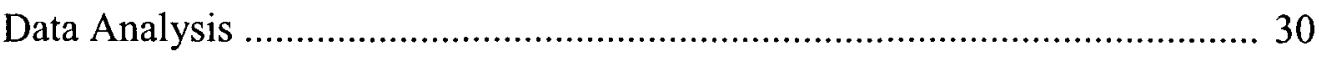

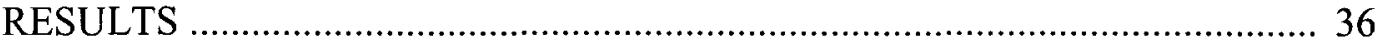

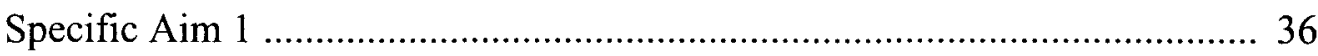

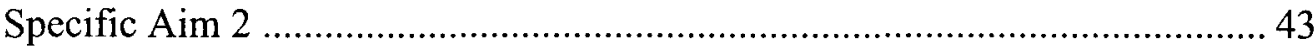

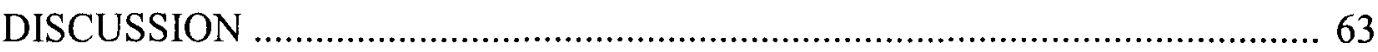

Characteristics associated with Performing Dangerous Tasks .......................... 63

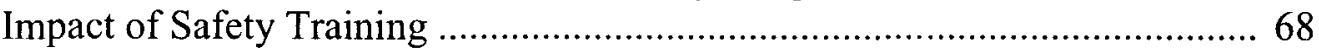

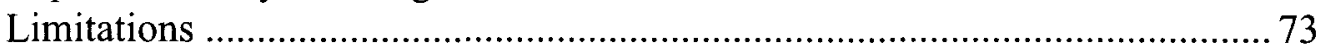

Summary and Implications ....................................................................... 74

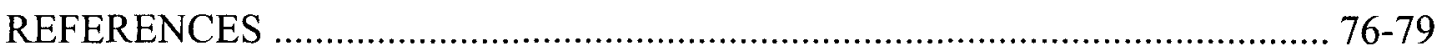

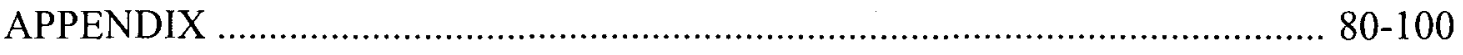

CURRICULUM VITAE ......................................................................... 101-103 


\section{LIST OF TABLES}

TABLE

PAGE

1. Hazardous occupations as defined in the hazardous occupations order ...... 9

2. Prohibited occupations for minors 14 and 15 years of age …...................... 10

3. Dangerous task selections from questionnaire, identified as prohibited, hazardous, or both

4. Demographic, behavioral, and work-related variables

5. Characteristics of teens who perform hazardous tasks versus those who do not

6. Characteristics of teens who perform prohibited tasks versus those who do not

7. Characteristics of teens who perform dangerous tasks versus those who do not

8. Dangerous task scores associated with characteristics of working teens .... 42

9. Relationship between hazardous task performance and prohibited task performance among all workers.

10. Hazardous task scores associated with prohibited task performance

11. Hazardous, prohibited, and dangerous task performance and safety training

12. Logistic regression predicting hazardous, prohibited and dangerous task performance by the receipt of safety training

13. Dangerous task score associated with receipt of safety training

14. Relationships between safety training methods and hazardous task performance among all trained teens (Abbreviated table) 46 (Full table) 
15. Logistic regression predicting hazardous task performance by the receipt of safety training methods among all trained teens (Abbreviated table) .... 47 (Full table)

16. Relationships between safety training methods and prohibited task performance among all trained teens (Abbreviated table) ............................ 48

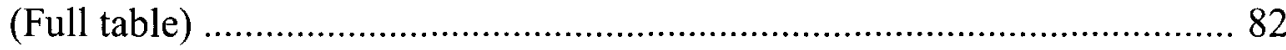

17. Logistic regression predicting prohibited task performance by the receipt of safety training methods among all trained teens (Abbreviated table) ..... 49

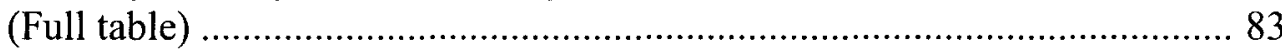

18. Relationships between safety training methods and dangerous task performance among all trained teens (Abbreviated table) ............................ 50

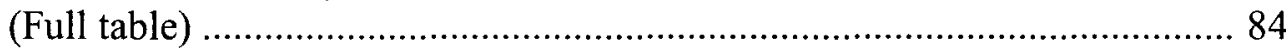

19. Logistic regression predicting dangerous task performance by the receipt of safety training methods among all trained teens (Abbreviated table) ..... 51

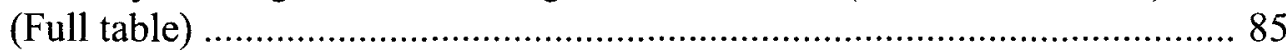

20. Differences in dangerous task scores between recipients of specific methods of safety training, among all trained teens who performed at least one dangerous task(Abbreviated table) ........................................................ 51

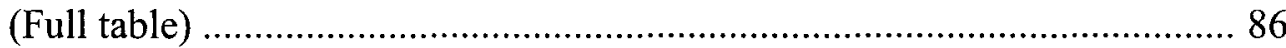

21. Differences in safety training method scores of those who performed hazardous, prohibited, and dangerous tasks ................................................. 52

22. Summary of results from analyses answering specific aim 2 , question $2 \ldots 53$

23. Relationships between safety training lessons and hazardous task performance among all trained teens (Abbreviated table) ........................... 54

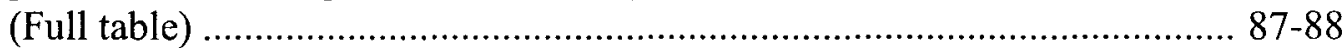

24. Logistic regression predicting hazardous task performance by the receipt of safety training lessons among all trained teens (Abbreviated table) ....... 55 (Full table) $89-90$

25. Relationships between safety training lessons and prohibited task performance among all trained teens (Abbreviated table) ............................. 55 (Full table) .................................................................................. 91-92

26. Logistic regression predicting prohibited task performance by the receipt of safety training lessons among all trained teens (Abbreviated table) ....... 56 (Full table) 
27. Relationships between safety training lessons and dangerous task performance among all trained teens (Abbreviated table) ............................ 56 (Full table)

28. Logistic regression predicting dangerous task performance by the receipt of safety training lessons among all trained teens (Abbreviated table) ....... 57 (Full table)

29. Differences in dangerous task scores between recipients of lessons of safety training, among all trained teens who performed dangerous tasks (Full table)

30. Summary of results from analyses answering specific aim 2, question $3 \ldots$...60-61

31. Linear trend relationships between length of safety training and performing hazardous, prohibited, and dangerous tasks, among all trained teens 61

32. Logistic regression predicting hazardous, prohibited and dangerous task performance by the length of safety training among all trained teens 


\section{OBJECTIVE AND AIMS}

This thesis is an analysis of data collected in 2010 and 2011 from teenagers in Jefferson County, Kentucky, that investigates the dangerous tasks that teens perform at work and evaluates the impact of safety training. For this thesis, dangerous tasks are defined as: (1) tasks that are prohibited by state and federal labor laws, and (2) other tasks that have been found to be hazardous in previous research. Although some research exists regarding young workers performing dangerous tasks, the influence of safety training has not been investigated. Safety training has been advocated as a means of preventing injury, but no research has characterized the safety training teens are given, and little research has documented its effectiveness in keeping teenagers safe. This study is the first to explore: (a) the characteristics of teens who perform dangerous tasks at work and (b) the effect that safety training has on preventing teens from performing dangerous tasks at work. 


\section{Objective}

The objective of this study was to characterize teenagers who perform dangerous tasks at work and to evaluate whether safety training prevents teens from performing dangerous tasks at work. Using data from a survey of high school students in Jefferson County, Kentucky, the following specific aims were addressed.

\section{Specific Aims}

a. Specific Aim 1. Compare the demographic characteristics of teenagers who perform dangerous tasks (hazardous and prohibited tasks) versus those who do not perform these tasks.

1. Are there significant differences between teens who perform hazardous tasks and teens who do not? (Age, race, gender, risk-taking behavior, late work hours, sleep, age when began working, supervision, parental communication)

2. Are there significant differences between teens who perform tasks that are prohibited by Kentucky state laws, and teens who do not? (Age, race, gender, risk-taking behavior, late work hours, sleep, age when began working, supervision, parental communication)

3. Are there significant differences between teens who perform dangerous tasks and teens who do not? (Age, race, gender, risk-taking behavior, late work hours, sleep, age when began working, supervision, parental communication)

4. Are teens who perform hazardous tasks also more likely to perform prohibited tasks? 
b. Specific Aim 2. Determine if safety training affects whether teens perform dangerous tasks (hazardous and prohibited tasks) at work.

1. Are teens who receive safety training less likely to perform hazardous, prohibited, or dangerous tasks than teens who do not receive safety training?

2. Are teens who receive certain methods of safety training less likely to perform hazardous, prohibited, or dangerous tasks than teens who receive other methods of safety training?

3. Are teens who learn certain lessons in safety training less likely to perform hazardous, prohibited, or dangerous tasks than teens who learn other lessons?

4. Are teens who receive safety training for a longer length of time less likely to perform hazardous, prohibited, or dangerous tasks than teens who receive safety training for a shorter length of time? 


\section{BACKGROUND}

Previous research has shown that adolescents face a number of hazards in the workplace, while using dangerous equipment and performing dangerous tasks. This thesis will focus on teenagers who perform dangerous tasks, the safety training they receive, and their injury and safety at work.

\section{Work-Related Injury among Youth \\ a. Prevalence and severity}

Work is an important part of adolescents' lives. It is estimated that between $44 \%$ and $64 \%$ of high school students work during a given school year (Dal Santo \& Bowling, 2009; Zierold et al., 2005; Weller et al., 2003) and 70\% to $80 \%$ have worked by the time they graduate high school (Centers for Disease Control and Prevention, 2003; Wegman \& Davis, 1999). An estimated $64 \%$ to $92 \%$ of teenagers in the United States work in service or retail jobs, such as in restaurants, supermarkets, or retail stores (Dal Santo \& Bowling, 2009; Runyan et al., 2009; Zierold et al., 2005; Weller et al., 2003; Herman, 2000). Injury often accompanies teenagers' work experiences. In research studies of working teenagers, between $15 \%$ and $41 \%$ report an injury at work (Rauscher \& Myers, 2008; Zierold \& Anderson, 2006; Zierold et al., 2005; Weller et al., 2003), and between $8 \%$ and $27 \%$ of

those injured sustain severe injuries, usually defined as requiring time off work or school, a change in daily activities for three or more days, or medical treatment (Rauscher \& 
Myers, 2008; Zierold \& Anderson, 2006; Breslin \& Smith, 2005; Weller et al., 2003).

The most common injuries sustained by working teenagers are cuts/lacerations, fractures/dislocations, and muscle sprains/strains (Breslin et al., 2007a; Breslin \& Smith, 2005).

\section{b. Age-related risk factors}

Young workers are twice as likely as adult workers to be injured on the job (Centers for Disease Control and Prevention, 2010). This may be due to a number of factors, including job-related differences, developmental differences, and psychosocial factors. In a multivariable analysis, Breslin and Smith (2005) found that occupation and physical exertion were important risk factors for injury, and the inclusion of these factors in the analysis lessened the impact of age. Young workers also lack experience and tend to hold temporary jobs and switch jobs often. This may increase their risk for being injured; 15-19 year-olds who have entered a new job within the past month have threefold the injury rate of those who had been a their job for over a year (Breslin \& Smith, 2006).

Additionally, since most teenagers are also in school and many participate in extracurricular activities, balancing time and responsibilities may leave teens distracted, fatigued, and more likely to get hurt. Over a third of teenagers in one study reported working 17 or more hours a week (Zierold \& Anderson, 2006; Zierold et al., 2005), and estimates of average hours worked per week range from $16.2-18.4$ hours per week (Rauscher \& Myers, 2008; Runyan et al., 2007). Weller et al. (2003) found that teens who work more than 21 hours per week had higher injury rates than those who worked 10 
hours or less per week and Breslin et al. (2007) found similar results that teens who work more hours per month are more likely to be injured on the job. Since most teenagers are also in school, they often work evenings, with the average teen working after 7:00 p.m. 2.5 nights a week; after 9 p.m. 2.3 nights a week; and after 11 p.m. 2.0 nights a week (Lewko et al., 2010). After a full day at school, teens are likely to be fatigued and may be more likely to be hurt.

Another influence on workplace safety is power dynamics, which may be experienced differently for young men and young women. In focus groups conducted with working teens, Canadian teenagers voiced feeling insignificant and easy to replace at work, which discouraged them from speaking up about their injuries and safety concerns (Breslin et al., 2007c). Many males and some females in male-dominated work settings also felt a need to prove themselves as mature adults and not appear weak by discussing injuries and safety concerns. Females more frequently expressed that if they did report injuries or voice concerns, their supervisors often did not take action in response (Breslin et al., 2007c).

Psychological differences may also impact teenagers' safety at work. Certain parts of the brain, including the prefrontal cortex, continue to develop throughout adolescence and into early adulthood (Galvan et al., 2007; Lenroot \& Giedd, 2006; Casey et al., 2005). This portion of the brain governs cognitive functions such as forming judgments, recognizing long-term consequences, and controlling impulses (Galvan et al., 2007; Lenroot \& Giedd, 2006; Casey et. al, 2005). Constraint and risk aversion also have been shown to continue developing during adolescence and into young adulthood (Blonigen et al., 2007). Such psychological developments likely have a large influence on 
teenagers' actions in high-risk environments like workplaces, and should be noted in assessing and developing effective safety training programs.

\section{c. Causes of injuries}

Data from the Bureau of Labor Statistics (BLS) has shown that the majority of injury in service and retail workers of all ages occurs because of falls, contact with an object, and overexertion, often due to lifting heavy objects or repetitive motion. The sources associated with these injuries are commonly containers, such as boxes, worker motion or position, contact with the ground, and machinery (Clarke, 2003). BLS data specific to youth 17 years old and younger has shown that the top causes of injury to working teenagers are contact with objects or equipment, falls, and bodily reaction and exertion (Windau \& Meyer, 2005). Research studies focusing on young workers have verified these sources of injury. Teenagers reported that the majority of their injuries were caused by falls or contact with objects, contact with hot grease or fluids, contact with knives or sharp objects, and lifting or carrying objects (Zierold et al., 2011; Breslin \& Smith, 2006; Zierold et al., 2005).

Other factors associated with workplace injury among teens include male gender (Breslin \& Pole, 2009; Breslin \& Smith, 2006; Breslin et al., 2006; Zierold \& Anderson, 2006; Salminen S, 2004; Weller et al., 2003), occupations in certain jobs, such as agriculture, construction, and industrial jobs (Breslin et al., 2003; Runyan \& Zakocs, 2000), and having recently started a new job (Breslin \& Smith, 2006). The impact of race and ethnicity on young workers' chances of injury has not been determined, as limited research exists on the topic. The research that does exist suggests that there may be an 
increased risk of injury for non-white youth working in predominately white communities (Breslin et al., 2007; Zierold \& Anderson, 2006), though a survey in a predominately Hispanic community found that decreased risks of injury for Hispanic workers as compared to white workers (Weller et al., 2003). However, after adjusting for covariates, the difference was no longer significant (Weller et al., 2003).

\section{Dangerous Tasks \\ a. Child labor laws}

Movements to place restrictions on child labor began as early as 1904 , with the foundation of the National Child Labor Committee. But the first nationwide law that places restrictions on child labor and has been upheld is the Fair Labor Standards Act (FLSA), passed in 1938. The law was passed during the Great Depression, when workers, including children, were desperate due to the economy. Children were working difficult factory jobs for sometimes less than $\$ 5$ a week, and great pressure was mounting to address the issue of child labor (Grossman, 1978). The child labor provisions under the FLSA serve to protect minors' physical and mental wellbeing, as well as their educational opportunities, with restrictions on the amount of hours and the times of day minors are allowed to work.

Over the years, the FLSA has been amended to prevent minors from working certain occupations, tasks, and hours. Additionally, states, including Kentucky, have enacted child labor laws; many which are more restrictive than the FLSA. When federal and state child labor laws conflict, the law that gives the most protection to the young workers applies. 


\section{b. Prohibited tasks}

The FLSA and Kentucky state labor laws place restrictions on occupations and tasks that youth under 18 years of age can perform at work, with specific laws for different age groups. Occupations such as manufacturing, mining, and roofing are illegal for minors under 18 years of age under the hazardous occupational orders (HOO). The HOO can be found in the federal documents, 29 CFR 570.50 through 570.68, and the 17 federal hazardous occupations are listed in Table 1.

Table 1. Hazardous occupations as defined in the hazardous occupations orders.

\begin{tabular}{|l|}
\hline Hazardous occupation \\
\hline $\begin{array}{l}\text { Occupations in plants or establishments involving manufacturing } \\
\text { or explosives }\end{array}$ \\
\hline Motor-vehicle driver and outside helper on a motor vehicle \\
\hline Coal mining \\
\hline Logging or sawmill occupations \\
\hline Operation of power-driven woodworking machines \\
\hline Exposure to radioactive substances \\
\hline Operation of power-driven hoisting apparatus, including forklifts \\
\hline $\begin{array}{l}\text { Operation of power-driven metal forming, punching, and shearing } \\
\text { machines }\end{array}$ \\
\hline Mining, other than coal mining \\
\hline $\begin{array}{l}\text { Operation of power-driven meat processing equipment, including } \\
\text { meat slicers and other food slicers, and most occupations in meat } \\
\text { slaughtering, packing, processing or rendering }\end{array}$ \\
\hline $\begin{array}{l}\text { Operation of power-driven bakery machines, including vertical } \\
\text { dough or batter mixers }\end{array}$ \\
\hline $\begin{array}{l}\text { Operation of power-driven paper products machines, including } \\
\text { scrap paper baler and cardboard box compactors }\end{array}$ \\
\hline Bricks, tile, and kindred products manufacturing \\
\hline $\begin{array}{l}\text { Operation of power-driven circular saws, band saws, guillotine } \\
\text { shears, chain saws, reciprocating saws, wood chippers, and } \\
\text { abrasive cutting discs }\end{array}$ \\
\hline $\begin{array}{l}\text { Occupations in wrecking, demolition, and shipbreaking } \\
\text { operations }\end{array}$ \\
\hline Roofing operations and on or about a roof \\
\hline Excavation operations \\
\hline
\end{tabular}


In addition to the $\mathrm{HOO}$, there are jobs and tasks prohibited for youth under 16 years old. Tasks such as cooking, baking, and using ladders or scaffolding are illegal for anyone under 16 years of age to perform (U.S. Department of Labor, 2011). Table 2 lists the occupations that are prohibited for 14-15 year-olds to work.

Table 2. Prohibited occupations for minors 14 and 15 years of age.

\begin{tabular}{|l|}
\hline Prohibited occupation \\
\hline $\begin{array}{l}\text { Manufacturing, mining, or processing occupations or occupations } \\
\text { in workrooms or workplaces where goods are manufactured, } \\
\text { mined, or processed }\end{array}$ \\
\hline Occupations involving operation or tending of hoisting apparatus \\
\hline $\begin{array}{l}\text { Work performed in or about boiler or engine rooms or in } \\
\text { connection with the maintenance or repair of the establishment, } \\
\text { machines, or equipment }\end{array}$ \\
\hline $\begin{array}{l}\text { Occupations involving operation or tending of any power-driven } \\
\text { machinery other than office machinery, vacuum cleaners and } \\
\text { floor waxers }\end{array}$ \\
\hline $\begin{array}{l}\text { Operation of motor vehicles, serving as helpers on motor } \\
\text { vehicles, and riding in or on the outside of a motor vehicle, } \\
\text { except special cases }\end{array}$ \\
\hline $\begin{array}{l}\text { Outside window washing involving working from window sills, } \\
\text { and all work using ladders, scaffolds, or their substitutes }\end{array}$ \\
\hline All baking and cooking, except special cases \\
\hline $\begin{array}{l}\text { Work in freezers and meat coolers and all work in preparation of } \\
\text { meats for sale, except special cases }\end{array}$ \\
\hline Youth peddling \\
\hline $\begin{array}{l}\text { Loading and unloading of goods or property onto or from motor } \\
\text { vehicles, railroad cars, or conveyors, except special cases }\end{array}$ \\
\hline $\begin{array}{l}\text { Catching and cooping of poultry in preparation for transport or } \\
\text { for market }\end{array}$ \\
\hline Public messenger service \\
\hline $\begin{array}{l}\text { Occupations involving transportation of persons or property by } \\
\text { rail, highway, air, water, pipeline or other means; warehousing } \\
\text { and storage; communications and public utilities; and } \\
\text { construction, except special cases }\end{array}$ \\
\hline
\end{tabular}

Employment for those younger than 14 years old is very restricted. Those younger than 14 can work in agricultural work deemed non-hazardous, family businesses except 
in manufacturing or hazardous jobs, in newspaper delivery, and in media or theatrical performances. Jobs within an individual's home, such as babysitting, are also allowed for minors under 14 years old (U.S. Department of Labor, 2011).

c. Hazardous tasks

In addition to the tasks that are prohibited by law, other tasks that teenagers perform at work may be deemed hazardous. Because falls, overexertion, sharp objects, and hot fluids or grease cause the majority of injuries among working teenagers, the tasks that expose teens to these hazards are potential points for intervention. For example, any working teenager is allowed by law to use sharp knives, but cuts and lacerations are among the most common injuries for teens.

A list of dangerous tasks, broken down by prohibited and dangerous, from the questionnaire used in this study is provided in Table 3. Hazardous tasks are those that are dangerous but not prohibited for an age group.

\section{d. Prevalence of dangerous tasks and recognition among teens}

Despite restrictions for working minors, nearly $37 \%$ of teenagers surveyed in one study reported being asked to perform a job or task that was prohibited by child labor laws for individuals their age (Rauscher et al., 2008). Among food services and grocery store employees, this percentage is as high as $52 \%$ for males and $43 \%$ for females (Runyan et al., 2007). Having a work permit in states that require them has been shown to protect against performing prohibited tasks (Dal Santo et al., 2010), but Kentucky is one of the few states that does not require work permits for youth employment. 
Table 3. Dangerous task selections from questionnaire, identified as prohibited, dangerous, or both.

\begin{tabular}{|c|c|c|c|c|}
\hline Task & $\begin{array}{l}\text { Prohibited for } \\
14-15 \text { year olds* }\end{array}$ & $\begin{array}{l}\text { Prohibited for } \\
\text { 16-17 year olds* }\end{array}$ & Dangerous** & Notes \\
\hline Cooked with ovens & $\mathrm{X}$ & & $\mathrm{X}$ & \\
\hline Operated fat fryers & $\mathrm{X}$ & & $\mathrm{X}$ & $\begin{array}{l}\text { Permitted for } 14-15 \text { year-olds if there is a device that lowers and } \\
\text { raises the basket automatically }\end{array}$ \\
\hline $\begin{array}{l}\text { Worked with hot } \\
\text { grease or hot fluids }\end{array}$ & $X$ & & $\mathrm{X}$ & $\begin{array}{l}\text { Permitted for } 14-15 \text { year-olds if the temperatures do not exceed } \\
140 \text { degrees }\end{array}$ \\
\hline Baking & $\mathrm{X}$ & & $\mathrm{X}$ & $\begin{array}{l}\text { The use of power-driven bakery machines is prohibited for 16-17 } \\
\text { year-olds }\end{array}$ \\
\hline $\begin{array}{l}\text { Food prep (not } \\
\text { cooking) }\end{array}$ & & & $\mathrm{X}$ & \\
\hline Used sharp knives & & & $\mathrm{X}$ & \\
\hline $\begin{array}{l}\text { Cleaned tables or } \\
\text { floors }\end{array}$ & & & $\mathrm{X}$ & \\
\hline Cleaned kitchens & & & $\mathrm{X}$ & \\
\hline \multicolumn{5}{|l|}{ Took trash outside } \\
\hline Used chemicals & & & $\mathrm{X}$ & \\
\hline \multicolumn{5}{|l|}{ Handled cash } \\
\hline Drove vehicle & $\mathrm{X}$ & $\mathrm{X}$ & $\mathrm{X}$ & $\begin{array}{l}\text { Occasional and incidental driving is permitted for 16-17 year- } \\
\text { olds under certain conditions }\end{array}$ \\
\hline Rode in vehicle & $\mathrm{X}$ & & $\mathrm{X}$ & $\begin{array}{l}\text { Riding in vehicles are permitted in certain situations for } 14-15 \\
\text { year-olds }\end{array}$ \\
\hline
\end{tabular}


Table 3 (Continued). Dangerous task selections from questionnaire, identified as prohibited, dangerous, or both.

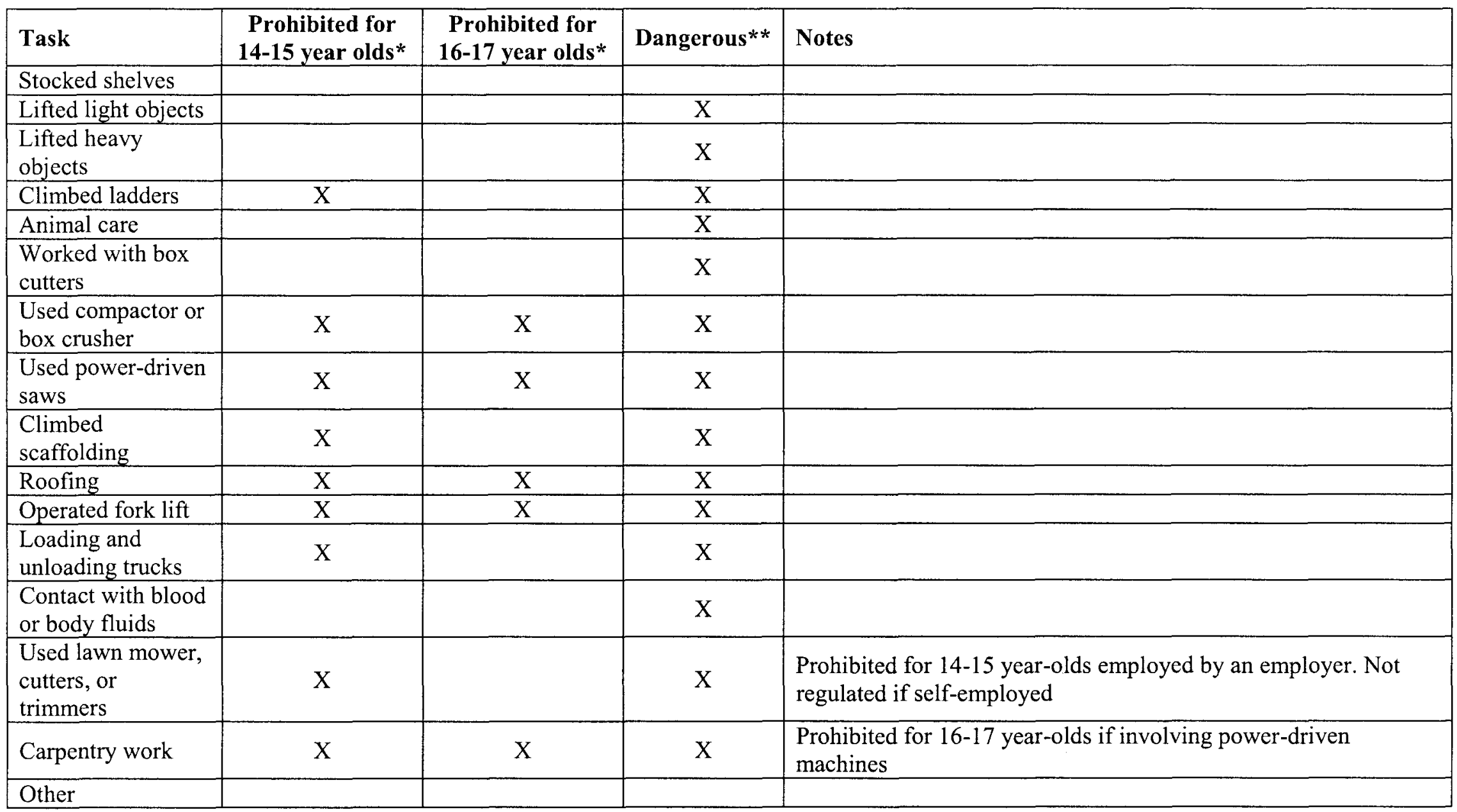

* Prohibited tasks are defined as those illegal by state and federal laws for minors of the above age groups to perform.

** Dangerous tasks are defined as any tasks that are considered dangerous. 
Teenagers have also reported high rates of performing tasks that are not prohibited but are known to be hazardous at work. Among teenagers working in food service and grocery stores, $71 \%$ reported using sharp knives and $68 \%$ used other sharp objects such as box cutters. Nearly fifty-five percent used grills or ovens and $36 \%$ used deep fat fryers (Runyan et al., 2007).

Despite these high proportions of teens performing dangerous tasks, most do not recognize the hazards they face at work. The same teenagers from the above study were asked whether they considered the tasks they do at work hazardous. Though many teenagers reported performing specific hazardous tasks, only $13 \%$ of those surveyed viewed one of their tasks to be dangerous (Vladutiu et al., 2010). Among teens who responded that they performed specific tasks known to be dangerous, very few actually viewed these tasks as such (Vladutiu et al., 2010).

\section{e. Injury and dangerous tasks}

Little research has examined the injury prevalence among teenagers who perform specific dangerous tasks at work. The research that does exist suggests that dangerous task performance is indeed related to injury among adolescents. Evensen et al. (2000) interviewed teenagers and classified the hazards they were exposed to in three categories: fall hazards, burn hazards and cut hazards. The researchers then performed a multivariable analysis and found a significant positive association between the number of types of hazards by working teenagers and injury (Evensen et al., 2000). More detailed analysis of the relationship between injury and the specific hazards are not available in 
this study, but it provides good evidence that hazardous tasks put working teenagers at risk of injury.

Some researchers have measured the danger of tasks using teenagers' perceptions of these tasks. Zierold and Anderson (2006) found that teenagers who reported being asked to do something dangerous at work were over twice as likely to be injured on the job than teens who reported otherwise. Frone (1998) also found a correlation between self-rated hazards in the workplace and injury among adolescents. In the sample of Zierold and Anderson's study (2006), only 7\% of teenagers said they were asked to do something dangerous at work, but as previously explained, most teens do not recognize the hazards at work as hazardous. Thus, self-report about performing dangerous tasks is likely an underestimation of the actual performance of hazardous tasks.

\section{Protection Against Work-Related Injury \\ a. Personal protective equipment}

One of the preventive measures that workplaces can take to protect their workers is to require teenagers to wear and use personal protective equipment (PPE), such as gloves, masks, or slip-resistant shoes. These items must be made available to all workers

who are placed in hazardous environments. Safety training and supervision should ensure that workers of all ages utilize PPE regularly and correctly to protect themselves from hazards on the job.

Unfortunately however, teens are not only performing illegal and hazardous tasks at work, but they also often neglect to take the necessary steps to protect themselves on the job. Runyan and her colleagues (2008) found that few teens performing hazardous 
tasks used the recommended PPE. For example, 55\% of teenagers surveyed reported exposure to thermal hazards, such as hot liquids, grease or hot surfaces, but only $26 \%$ of these teens ever had used burn protection, like oven mitts or safety gloves. Teenagers performing hazardous tasks who received PPE training reported slightly higher use than teenagers who did not receive this training (Runyan et al., 2008). This evidence emphasizes the importance for more research on safety behaviors, such as PPE use among teens, safety training, and potential engineering or administrative controls. Changes in personal behavior, such as PPE use, though important to encourage, can be very difficult to change. Therefore, systematic changes, such as training programs and legal changes regarding dangerous tasks may help protect teenagers from injury.

\section{b. Safety Training}

Safety training among teenagers has just begun to be assessed in terms of its effectiveness of preventing injury. The studies that exist have shown that most teenagers receive safety training at work (Lewko et al., 2010; Runyan et al., 2007; Zierold \& Anderson, 2006), but that it is not protective against injury (Zierold \& Anderson, 2006). Safety training has not been assessed with respect to preventing performance of hazardous or prohibited tasks at work, but one study by Vladutiu et al., (2010) did examine whether safety training impacted teens' ability to recognize hazards in the workplace. Safety training was not associated with improved hazardous task recognition overall, but was associated with better hazardous task recognition in some sectors. 


\section{Summary and Justification for Research}

Most teenagers today work and as many as two in every five teenagers get hurt on the job. Up to a quarter of these teenagers have injuries severe enough to interfere with their daily activities. Teenagers are injured more often than adults at work for a number of reasons, including psychosocial factors in the workplace. Given that these individuals are still developing physically and cognitively, injuries may be especially dangerous for young workers. Injuries in the workplace can have lasting physical and mental ramifications on teenagers' lives, and the problem merits research to prevent such injuries.

Teenagers who work commonly perform dangerous tasks on the job, and research has suggested that performing dangerous tasks puts teenagers' safety at risk. Teens performing hazardous and prohibited work often fail to recognize the hazards that are present and the laws that prohibit their tasks. Safety training may help improve hazardous task recognition and knowledge of how to respond to dangerous conditions or tasks, but more research is needed. To date, there is no detailed assessment of the methods, lessons, and length of safety training that teen workers receive, nor is there research that provides an understanding if these have an impact on dangerous task performance. This thesis aims to address these topics. 


\section{METHODS}

\section{Data Collection}

The data for this thesis comes from a federally funded study that was a two-stage project using qualitative and quantitative research methods to investigate work, injury, safety training, and supervision among teenagers in Jefferson County, Kentucky. This study was approved by the University of Louisville Institutional Review Board and the Jefferson County Public Schools Institutional Review Board. Teenagers were recruited from two public high schools in Jefferson County, Kentucky. Both schools in the study are magnet career academies, providing a traditional high school curriculum as well as a number of specialized courses in varied careers. One school is an inner-city school with approximately 1,100 students. Seventy-eight percent of the student body is African American, $8 \%$ is white, and $14 \%$ is other minorities. This school offers career-training programs for students in the fields of medicine, law and government, business, and technology. The second school in the study serves a suburban working-class population, with approximately 1,900 students, $70 \%$ of whom are white, $25 \%$ African-American and $4 \%$ other minorities. This school offers career-training programs in communications, media, and fine arts.

The first stage of the project was conducted in Spring 2010 and involved recruiting employed teenagers for focus groups and interviews. The results from the focus groups and interviews were used to create a questionnaire for the second stage of the study. The 
second stage of the study involved distributing two surveys in the same two high schools. The first survey, distributed in winter 2011, focused on summer employment, and the second, in spring 2011, focused on school-year employment.

\section{a. Focus groups: Recruitment of participants and data collection}

The methods for the qualitative part of the study have been previously described (Zierold et al., 2012). In brief, 42 working teenagers were recruited during lunch periods at each school for several days one week. In order to participate, students needed to currently hold a job and be 15 years old or older. Students who were interested and eligible to participate were given consent forms. If they were under 18 years old, the forms had to be signed by their parents or guardians and returned; if students were 18 years or older, they signed the forms and signed up for a focus group or interview. Most of the consent forms were returned within a few days. If a student did not return the consent form, the study team gave him or her a phone call reminder. Each participant also received a phone call reminder the evening before his or her scheduled interview or focus group.

Teenagers were either interviewed individually or participated in focus groups after school in a conference room at their school. Interviews lasted approximately one hour and focus groups lasted approximately an hour and a half to two hours. Participants younger than 18 years of age assented to participating before the discussions began. Members of the research team trained in interviewing and focus group facilitation ran the discussions using a semi-structured guide. The discussions included descriptions of the teenagers' jobs, the safety training and supervision they receive at work, and the injuries they sustained while working. At times, additional prompting by the interviewers was 
needed to encourage discussion or clarify responses. At the end of the sessions, students were allowed to ask the study team questions about their research. Each student who participated received a $\$ 25$ gift card as compensation.

\section{b. Survey: Recruitment of participants and data collection}

At the inner city high school, questionnaires and consent forms were distributed to the teachers in the career magnet program. Teachers distributed the consent forms to teenagers to give to their parents or guardians a few days before the survey. If parents or guardians felt uncomfortable with their child participating or had questions about the study, contact information for the principal investigator was provided. A few days later, teachers were asked to give the questionnaires to all of their students, regardless of their employment status. An assent form was attached to the questionnaire and students kept this form. The teachers were compensated with $\$ 35$ gift cards for each class of completed questionnaires that they returned.

The above recruitment strategy was proposed but rejected by the administration of the suburban high school. Thus, a different recruitment strategy that was acceptable to the administration was used to obtain questionnaire responses. The research team recruited students during lunch periods over a three-day period during one week. Teens were screened by the principal investigator to confirm their employment status. They then received a questionnaire to take during their lunch period. Attached to the questionnaire was an assent form. Once the students completed the questionnaire, they returned them to the research team and received a consent form to bring to their parents or guardians. The consent form listed a number that corresponded with their questionnaire number, so that if their guardians were uncomfortable with their child's participation in the study, the 
principal investigator could be contacted and their child's questionnaire could be destroyed and removed from the study data. No parents or guardians contacted the principal investigator. After completing the questionnaire, the teenagers selected an incentive item from University of Louisville or University of Kentucky.

\section{Data Input and Quality Control Measures}

All of the discussions in the focus groups and interviews were audio-recorded. Members of the research team transcribed the discussions verbatim. If there were questions about what was said in a discussion or the speaker, other members of the research team listened to give input. If they could still not decipher the speaker or what was said, the information that was known was recorded and the other was labeled as unknown.

For the quantitative data input, members of the research team first skimmed through the questionnaires for suspicious patterns of answers, such as contradictory answers, multiple answers when one answer was requested, or nonsensical answers. The principal investigator then examined all of the suspicious questionnaires and made the final judgment on retaining or omitting the questionnaire from the sample. Then, each questionnaire was scanned into a computer designated for the study. The data was extracted from these scanned files using Remark Office OMR ${ }^{\circledR}$ software. The program highlighted multiple responses, written-in answers, and blank answers, and a member of the research team went through each of these individually to verify the answer using an image of the questionnaire or the hard copy if necessary. 


\section{Study Population}

The population for the qualitative part of the study consisted of 42 teenagers. Five focus groups and seven individual interviews were held. Sixty-nine percent of those participating were African-American, 26\% were white, and 5\% were Hispanic. Slightly more females (57\%) participated than males. Ages ranged from 15-19 years old, with a mean age of 17.14 years. Over half $(56 \%)$ of the teens reported working in restaurants, food services, or retail jobs; however, a variety of other jobs were represented.

A total of 884 students completed the questionnaire that collected data regarding school-year employment. Of the 884 students who completed questionnaires, 398 (45\%) worked during the past school year. Fifty-two students were excluded from the analysis because they were 18 years or older, thus not bound by child labor laws, and 20 students were excluded from the analysis because they either did not mark a job or marked two or more jobs where only one job was to be indicated. After excluding those 72 students, a total of 326 working students remained in the sample -89 working students from the inner-city school and 237 working students from the suburban school. The final population of students used for the analyses in this thesis was $58 \%$ female, $48 \%$ white, $41 \%$ African-American, and $11 \%$ other minorities. Seventy-nine percent of the students were 16 or 17 years old and $21 \%$ were 14 or 15 years old. Sixty-five percent of the teenagers reported working in restaurants or retail jobs.

\section{Measures}

Table 4 describes the demographic, behavioral and work-related variables that are used in the analysis. The variables that were used to characterize safety training and dangerous tasks are expanded upon in the sections following Table 4. 
Table 4. Demographic, behavioral, and work-related variables

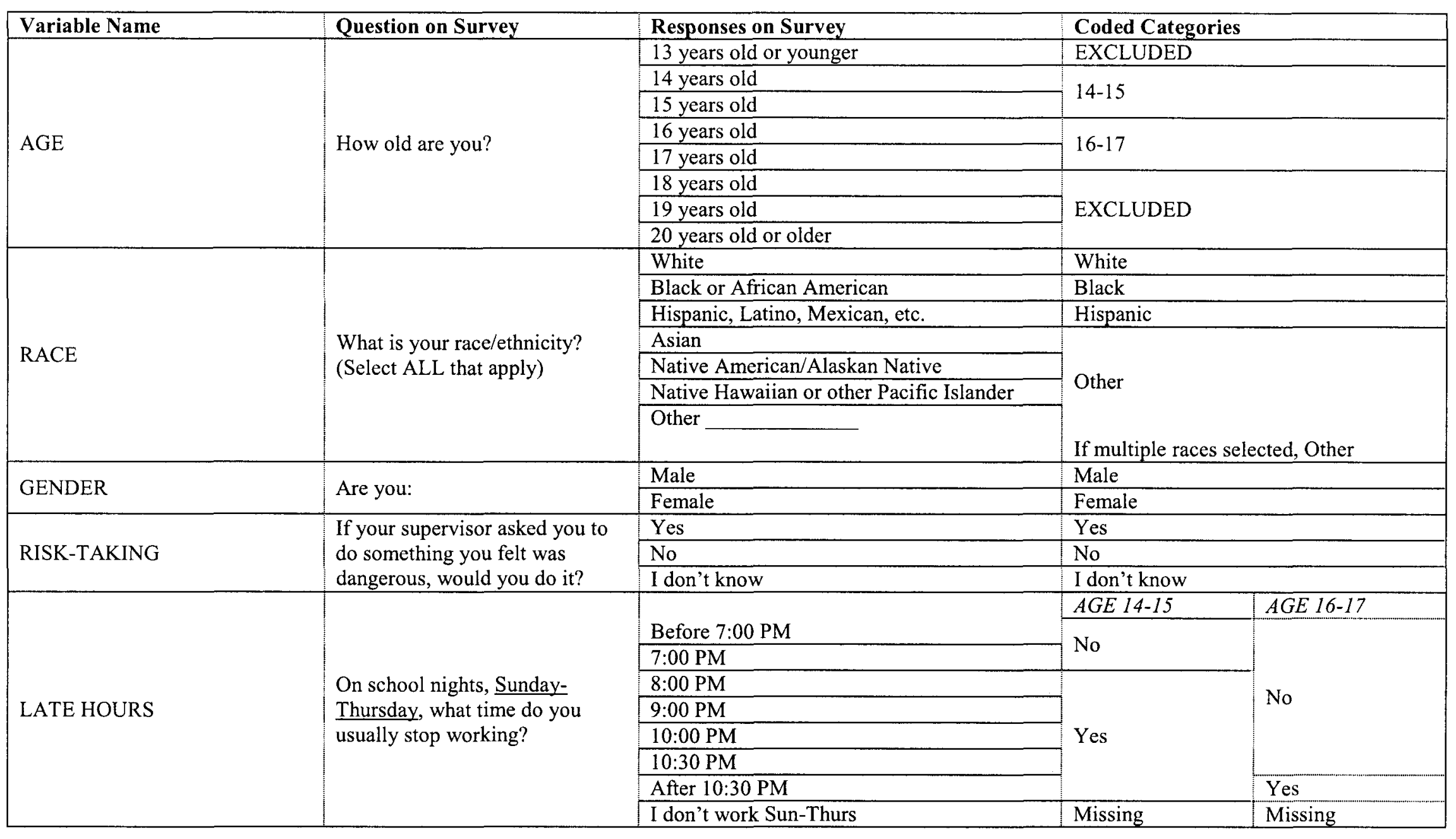


Table 4 (Continued). Demographic, behavioral, and work-related variables

\begin{tabular}{|c|c|c|c|c|}
\hline \multirow{7}{*}{ LATE HOURS (CONTINUED) } & \multirow{7}{*}{$\begin{array}{l}\text { On non-school nights, Friday } \\
\text { and Saturday, what time do you } \\
\text { usually stop working? }\end{array}$} & Before 7:00 PM & \multirow{2}{*}{ No } & \multirow{4}{*}{ No } \\
\hline & & $7: 00 \mathrm{PM}$ & & \\
\hline & & 9:00 PM & \multirow{4}{*}{ Yes } & \\
\hline & & $10: 00 \mathrm{PM}$ & & \\
\hline & & $12: 00 \mathrm{AM}$ & & \multirow[t]{2}{*}{ Yes } \\
\hline & & After 12:00 AM & & \\
\hline & & I don't work Fri-Sat & Missing & Missing \\
\hline \multirow{3}{*}{ SLEEP PER NIGHT } & \multirow{3}{*}{$\begin{array}{l}\text { During the school year, on } \\
\text { average, how many hours of } \\
\text { sleep do you get each night? }\end{array}$} & 6-7 hours & \multicolumn{2}{|c|}{$6-7$ hours } \\
\hline & & $8-9$ hours & \multirow{2}{*}{\multicolumn{2}{|c|}{$8+$ hours }} \\
\hline & & 10 or more hours & & \\
\hline \multirow{4}{*}{ FIRST STARTED WORKING } & \multirow{4}{*}{$\begin{array}{l}\text { How old were you when you } \\
\text { first started working? }\end{array}$} & Younger than 13 years old & \multirow{2}{*}{\multicolumn{2}{|c|}{13 years old or younger }} \\
\hline & & 13 years old & & \\
\hline & & 14 years old & \multicolumn{2}{|c|}{14 years old } \\
\hline & & 15 years old & \multicolumn{2}{|c|}{15 years old } \\
\hline \multirow{3}{*}{$\begin{array}{l}\text { FEEL THEY GET ENOUGH } \\
\text { SUPERVISION }\end{array}$} & \multirow{3}{*}{$\begin{array}{l}\text { Do you feel you get enough } \\
\text { supervision at work? }\end{array}$} & Yes & \multicolumn{2}{|l|}{ Yes } \\
\hline & & No & \multicolumn{2}{|l|}{ No } \\
\hline & & I don't know & \multicolumn{2}{|c|}{ I don't know } \\
\hline \multirow{3}{*}{$\begin{array}{l}\text { SUPERVISOR MAKES SURE } \\
\text { THEY UNDERSTAND } \\
\text { WORKPLACE SAFETY }\end{array}$} & \multirow{3}{*}{$\begin{array}{l}\text { Does your supervisor make sure } \\
\text { you understand workplace } \\
\text { safety? }\end{array}$} & Yes & \multicolumn{2}{|l|}{ Yes } \\
\hline & & No & \multicolumn{2}{|l|}{ No } \\
\hline & & I don't know & \multicolumn{2}{|c|}{ I don't know } \\
\hline & & Never & 1 & \\
\hline & How often do you talk to your & Rarely & 1 & \\
\hline $\begin{array}{l}\text { 1ELL I HEIR PARENIS } \\
\text { ABOUT WORK }\end{array}$ & parent(s)/guardian about what & Every once in a while & 2 & \\
\hline & you do at work? & Sometimes & 3 & \\
\hline & & Almost always & 4 & \\
\hline
\end{tabular}




\section{a. Safety training}

In the questionnaire, students were asked whether they received safety training in multiple questions. Some research has shown that teens do not understand what safety training is or confuse it with job training. Since the number of students who responded that they received safety training was different in each question, one question was chosen to define safety training due to the clarity and detail of the question. Students were asked: "Safety training may include ways to prevent accidents. Does your job include any of the following methods of safety training?" Responses included: "I did not have safety training", "Safety videos", "Written safety quizzes", "Safety lectures", "Safety posters/signs", "Computer safety quizzes", "Safety video games", "On-the-job safety demonstrations", "Reading safety materials", "Practicing accident response", and "Other", where a respondent could fill in a blank corresponding the method they received. Respondents were allowed to choose more than one answer. If respondents marked that they did not have safety training, their receipt of safety training was defined in this analysis as "no". If respondents marked any other response including a variety of methods of safety training, their receipt of safety training was defined as "yes".

To assess whether multiple methods of training were more effective than one method, a safety training method score was calculated among those teens that reported receiving at least method. This score was a summation of the number of methods that a teenager reported receiving. For example, if a teen selected "videos," "safety lectures," and "written quizzes," then the safety training method score was equal to 3 . Scores could range from 1 to 10 . 
Another aspect of safety training that was evaluated was whether specific lessons learned during safety training were effective in preventing a teen from performing a dangerous task. The questionnaire included two questions to assess this: "During your safety training, what did you learn?" and "Continuing from above - during your safety training what did you learn?" Respondents were allowed to mark more than.one answer in each question. The possible answers for the first question were "I did not have safety training", "Ways to spot hazards", "Ways to control or remove hazards", "How to read warning labels", "Where to locate MSDS", "How to read MSDS", What personal protective equipment I need (boots, mask, eye wear, gloves)", "First aid skills", "Child labor laws", "What chemicals are at my job", and "Other", which had a space for respondents to fill in what they learned. The second question's possible responses were "I did not have safety training", "How to operate the equipment", "How to do my job", "What to do when someone is injured", "What to do during a robbery", "Safe lifting practices", "Safe climbing practices", "How to prevent slips, trips, and falls", "What job tasks I should NOT do", and "Safe driving techniques."

To further characterize safety training, teens were asked: "How much time was spent on safety training when you first started working at your job?" The possible responses were "None", "Less than 30 minutes", "30-60 minutes", "More than 1 hour", and "I don't remember". For the purpose of this analysis, students who responded that they did not remember the length of their safety training were classified as having a missing response. 


\section{b. Dangerous tasks}

According to the existing literature on young workers, dangerous tasks are defined as those that involve sharp objects, hot surfaces or hot liquids, chemicals, lifting or carrying objects, working on ladders or scaffolding, and operating or working near dangerous equipment. Some of these tasks are prohibited by law, but others are simply considered hazardous. For the analyses performed in this thesis, the phrase "dangerous tasks" includes both these categories of tasks (prohibited and hazardous).

To determine what dangerous tasks teenagers were performing, the questionnaire asked: "What tasks do you do for your job?" There were a total of 35 tasks that were listed that teens could choose, as well as an "other" category. Teens could select multiple responses. If a teen of any age responded that he or she performed any of the following tasks, their exposure to dangerous tasks was defined as "yes":

$\begin{array}{ll}\text { Used food slicers } & \text { Lifted heavy objects } \\ \text { Cooked with ovens } & \text { Climbed ladders } \\ \text { Cooked with grills } & \text { Animal care } \\ \text { Operated fat fryers } & \text { Worked with box cutters } \\ \text { Worked with hot grease or hot fluids } & \text { Used compactor or box crusher } \\ \text { Worked near hot surfaces } & \text { Used power-driven saws } \\ \text { Baking } & \text { Climbed scaffolding } \\ \text { Did food prep other than cooking } & \text { Roofing } \\ \text { Used sharp knives } & \text { Operated fork lift } \\ \text { Cleaned tables or floors } & \text { Loading and unloading trucks } \\ \text { Cleaned kitchens } & \text { Contact with blood or body fluids } \\ \text { Used chemicals } & \text { Used lawn mower, cutters, or } \\ \text { Drove vehicle } & \text { trimmers } \\ \text { Rode in vehicle } & \text { Carpentry work } \\ \text { Lifted light objects } & \end{array}$

If teens did not perform any of the above tasks, their exposure to dangerous tasks was defined as "no". 
Additionally, a dangerous task score was calculated for those who reported performing at least one dangerous task. The number of dangerous tasks was added to create the score. Scores could range from 1 to 28 .

c. Prohibited tasks

Prohibited tasks are defined as those tasks that are illegal according to labor laws.

If teens were 14 or 15 years old and responded that they performed one or more of the following tasks, their exposure to prohibited tasks was defined as "yes":

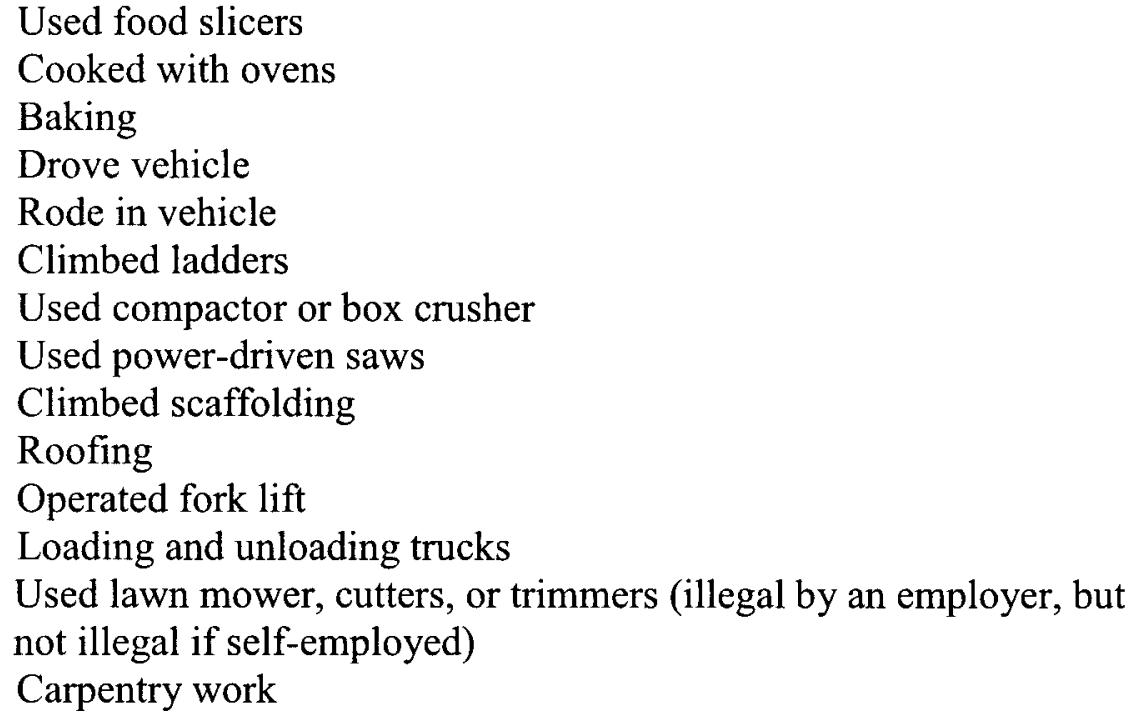

If teenagers were aged 16 or 17 years old, and responded that they performed one or more of the following tasks, their exposure to prohibited tasks was defined as "yes":

Used food slicers

Drove vehicle

Rode in vehicle

Used compactor or box crusher

Used power-driven saws

Roofing

Operated fork lift

Carpentry work (Illegal if involving power-driven woodworking machines)

Otherwise, exposure to prohibited tasks was defined as "no". 


\title{
d. Hazardous tasks
}

Hazardous tasks are defined as tasks that are considered dangerous but are not currently regulated by labor laws. Therefore, for this analysis, hazardous tasks are those listed in the dangerous task list that are not listed in the prohibited task list for a certain age group. Thus, for 14 and 15 year-olds, if any of the following hazardous tasks were marked on a questionnaire, the respondent's performance of hazardous tasks was defined as "yes":

\author{
Cooked with grills \\ Operated fat fryers \\ Worked with hot grease or hot fluids \\ Worked near hot surfaces \\ Did food prep other than cooking \\ Used sharp knives \\ Cleaned tables or floors \\ Cleaned kitchens \\ Used chemicals \\ Lifted light objects \\ Lifted heavy objects \\ Animal care \\ Worked with box cutters \\ Contact with blood or body fluids
}

For 16 and 17 year-olds, performance of hazardous tasks was defined as "yes" if they

mark that they performed any of the following tasks:

Cooked with ovens
Cooked with grills
Operated fat fryers
Worked with hot grease or hot fluids
Worked near hot surfaces
Baking
Did food prep other than cooking
Used sharp knives
Cleaned tables or floors
Cleaned kitchens
Used chemicals

Lifted light objects

Lifted heavy objects

Climbed ladders

Animal care

Worked with box cutters

Climbed scaffolding

Loading and unloading trucks

Contact with blood or body fluids

Used lawn mower, cutters, or

trimmers

Otherwise, respondents' exposure to hazardous tasks was defined as "no". 
To evaluate the effect of multiple hazardous tasks, a hazardous task score was calculated, by adding the number of tasks each teenager reported. Scores could range from 1 to 20 .

\section{Data Analysis}

a. Qualitative data analysis: Focus groups and interviews

The qualitative data analysis methods used in this study are thoroughly described by Zierold et al. (2012) and briefly reported here. Three members of the research team transcribed verbatim the interviews and focus groups. The data was then analyzed using inductive thematic analysis (Braun \& Clarke, 2006; Patton, 1990). This method allows themes to emerge from the data rather than analyzing the data through the researchers' preconceived themes. Once the discussions were transcribed, three members of the research team read each transcript multiple times. Each research team member individually coded and categorized responses according to the themes they observed. Then the research team discussed as a group the themes that emerged from the data. A consensus on the main themes was reached and all of the transcripts were further analyzed with respect to these themes.

\section{b. Quantitative data analysis: Survey results}

The analytical methods are presented for each question in the 2 specific aims. 


\section{i. Specific Aim 1}

Question 1: Are there significant differences between teens who perform hazardous tasks and teens who do not?

To determine whether there were significant demographic or work-related differences between teens who perform hazardous tasks and those who do not, multiple chi-square tests were performed. The outcome variable was the dichotomous hazardous task variable, and the following predictor variables were tested in separate analyses: age, race, gender, risk-taking behavior, late work hours, hours of sleep per night, age when first started working, the feeling that one gets enough supervision at work, the perception that one's supervisor makes sure they understand workplace safety, and frequency of communication with their parents about their work. The Cochran-Armitage trend test was used to identify the statistically significant trends in the ordered variables: sleep per night, age when first started working, and frequency of communication with their parents.

Question 2: Are there significant differences between teens who perform tasks that are prohibited by Kentucky state laws, and teens who do not?

Chi-square tests were used to measure the differences in the predictor variables mentioned in question 1 between teens who perform tasks prohibited by child labor laws and teens who do not. For these analyses, performance of prohibited tasks was the dichotomous outcome. The ordered variables, sleep per night, age when first began working, and frequency of communication with their parents were tested for trends using the Cochran-Armitage trend test. 
Question 3: Are there significant differences between teens who perform dangerous tasks and teens who do not?

Chi-square tests using the predictors in question 1 and question 2 were performed with the dichotomous dangerous task variable as the outcome. The Cochran-Armitage trend test examined whether trends existed in dangerous task performance among the ordered variables.

To examine differences in the number of dangerous tasks teenagers performed, Mann-Whitney-Wilcoxon tests were used. The dangerous task score was the ordinal outcome, and each of the demographic and work-related characteristics were predictor variables in separate analyses.

Question 4: Are teens who perform hazardous tasks also more likely to perform prohibited tasks?

A chi-square test was used to determine whether teens who perform hazardous tasks are more likely to perform prohibited tasks. A Mann-Whitney-Wilcoxon test measured the association between a teenager's hazardous task score and performance of prohibited tasks, as a dichotomous outcome.

ii. Specific Aim 2:

Question 1: Are teens who receive safety training less likely to perform hazardous, prohibited, or dangerous tasks than teens who do not receive safety training?

To determine whether teenagers who received safety training were less likely to perform hazardous, prohibited, and dangerous tasks, chi-square tests, Mann-Whitney- 
Wilcoxon tests, invariable logistic regressions, and multivariable logistic regressions were conducted. The exposure variable for the chi-square tests was the dichotomous receipt of safety training. The outcomes measured were the dichotomous performing of hazardous, prohibited, and dangerous tasks. The Mann-Whitney-Wilcoxon tests analyzed the continuous dangerous task score. Univariable and multivariable logistic regression was used to examine receipt of safety training as a predictor of hazardous, prohibited, and dangerous task performance. The multivariable logistic regression models controlled for variables found to be significant predictors of the outcome variables using the purposeful selection algorithm (Bursac et al., 2008).

Question 2: Are teens who receive certain methods of safety training less likely to perform hazardous, prohibited, or dangerous tasks than teens who receive other methods of safety training?

Methods of safety training, as outlined in section IV.a., were examined as predictors of whether a teen performs hazardous, prohibited, and dangerous tasks. Chisquare tests were used to determine whether teens who received a given method of safety training have a significantly different likelihood of performing hazardous, prohibited, and dangerous tasks than those who receive other safety training methods. Mann-WhitneyWilcoxon tests were used to measure the impact of multiple safety training methods, in the form of the safety training method score, on the performance of hazardous, prohibited, and dangerous tasks. It was also used to evaluate the dangerous task scores associated with each safety training method. Univariable logistic regression was used to measure each safety training method as a predictor of hazardous, prohibited, and 
dangerous tasks. Finally, multivariable logistic regressions estimated the role of methods of safety training on teens' performance of hazardous, prohibited, and dangerous tasks.

Question 3: Are teens who learn certain lessons in safety training less likely to perform hazardous, prohibited, or dangerous tasks than teens who learn other lessons?

Analyses similar to those described in question 2 were conducted to analyze the effects of lessons of safety training, as outlined in section IV.a., on the performance of hazardous, prohibited, and dangerous tasks. Chi-square tests were conducted for each lesson of safety training with hazardous, prohibited, and dangerous task performance as dichotomous outcomes in separate analyses. Mann-Whitney-Wilcoxon tests were used to identify differences between the dangerous task scores of those who received each safety training lesson. Univariable logistic regression was used for each safety training lesson as predictor variables and hazardous, prohibited, and dangerous tasks as separate outcome variables. Finally, multivariable logistic regressions estimated the effect of safety training lessons on teens' performance of hazardous, prohibited, and dangerous tasks.

Question 4: Are teens who receive safety training for a longer length of time less likely to perform hazardous, prohibited, or dangerous tasks than teens who receive safety training for a shorter length of time?

Length of safety training was also assessed with respect to performing hazardous, prohibited, and dangerous tasks. Cochran-Armitage trend tests were conducted to evaluate whether longer length of safety training was associated with lower prevalence of 
performing hazardous, prohibited, and dangerous tasks. Univariable and multivariable logistic regressions were used to measure the effect of length of training on the dichotomous variables of performing of hazardous, prohibited, and dangerous tasks. 


\section{RESULTS}

The results from the analyses are presented here. For some analyses, the tables only include significant or borderline significant findings, but tables with the complete results can be found in the appendix.

\section{Specific Aim 1}

a. Question 1: Are there significant differences between teens who perform hazardous tasks and teens who do not?

Seventy-nine percent $(\mathrm{n}=238)$ of teenagers reported performing a hazardous task at work. Results from the chi-square analyses between those who performed hazardous tasks and those who did not are found in Table 5. These analyses revealed that there is a statistically significant relationship between sleep per night and a teen's likelihood to perform a hazardous task $(\mathrm{p}=0.05)$ though the relationship is not linear $(\mathrm{p}$-trend $=0.35)$. However, the age a teen first began working does have a linear relationship with the likelihood of performing hazardous tasks ( $\mathrm{p}$-trend $=0.02$ ); teens who first began working when they were older had the lowest prevalence of hazardous task performance. Though not statistically significant at the 0.05 alpha level, the data indicate a possible relationship between gender and hazardous task performance, with males being more likely to perform hazardous tasks $(\mathrm{p}=0.08)$. 
Table 5. Characteristics of teens who perform hazardous tasks versus those who do not

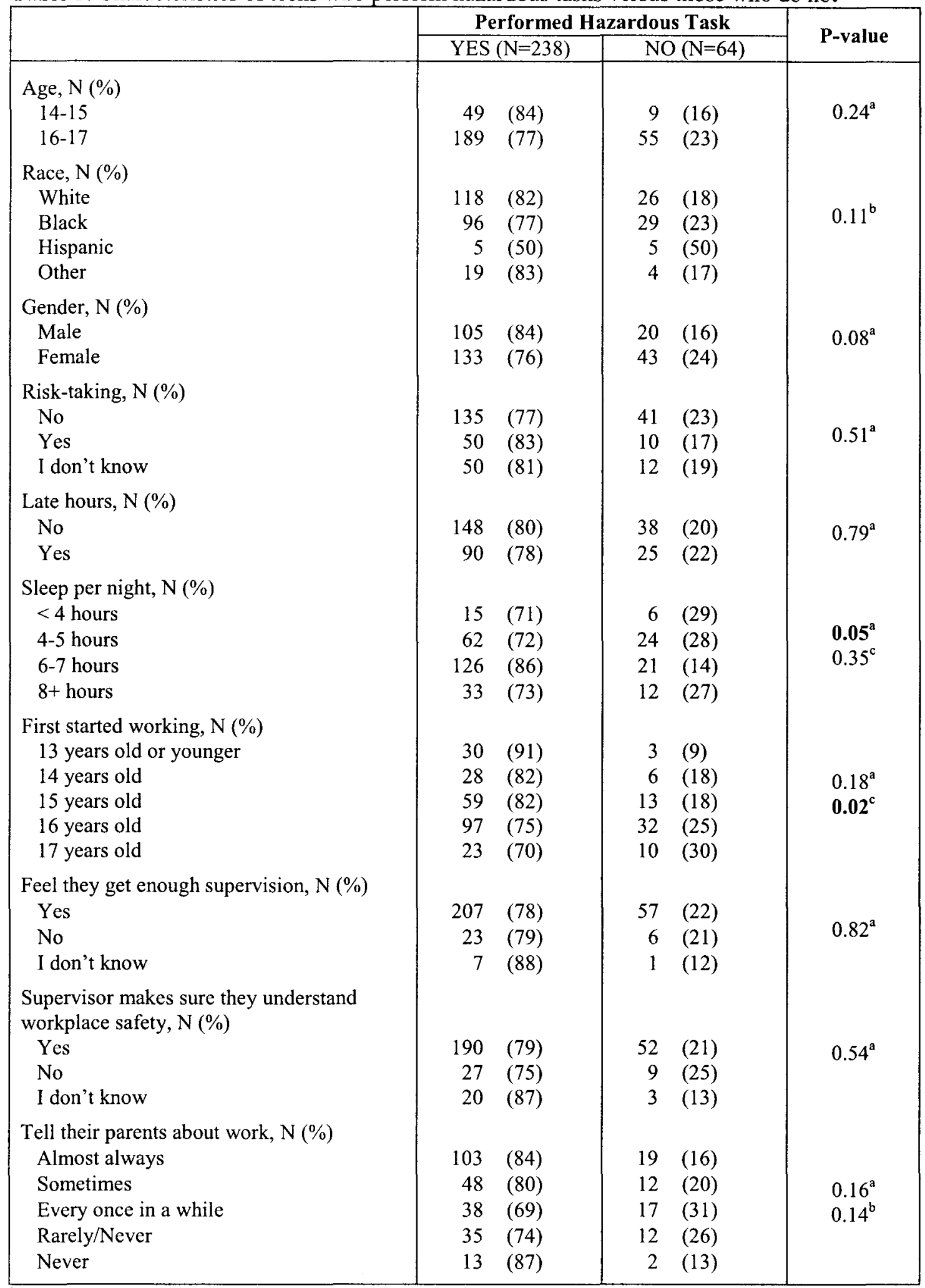

${ }^{a}$ Corresponds to chi-square test

${ }^{\mathrm{b}}$ Corresponds to Fisher's exact test

${ }^{\mathrm{C}}$ Corresponds to Cochran-Armitage trend test 
b. Question 2: Are there significant differences between teens who perform tasks that are prohibited by Kentucky state laws, and teens who do not?

Twenty-eight percent $(\mathrm{n}=84)$ teens reported performing tasks prohibited by law for their age. Table 6 reports the results from the chi-square analyses of characteristics of those who performed prohibited tasks and those who did not. As with hazardous task performers, prohibited task performers were more likely to have started working at a younger age $($ Chi-square $\mathrm{p}$-value $=0.04, \mathrm{p}$-trend $<0.01)$. Other statistically significant factors were gender, with males being more likely to perform prohibited tasks $(\mathrm{p}=0.01)$ and race, with Hispanic teens the least likely and white teens the most likely to perform prohibited tasks $(\mathrm{p}=0.01)$. Teens who felt that their supervisor makes sure they understand workplace safety were also less likely to perform prohibited tasks ( $\mathrm{p}=0.01)$.

c. Question 3: Are there significant differences between teens who perform dangerous tasks and teens who do not?

Eighty-one percent $(\mathrm{n}=247)$ teenagers reported performing dangerous tasks, that is, either tasks that are considered hazardous or tasks prohibited for their age. Chi-square comparisons of characteristics of teens who performed dangerous tasks and those who did not are shown in Table 7. Based on these analyses, gender, sleep, and age at which one started working were all associated with dangerous task performance $(\mathrm{p}=0.03$, $\mathrm{p}=0.03$, and $\mathrm{p}$-trend $<0.01$, respectively). A borderline significant relationship between race and dangerous task performance was observed, with white teens the most likely to perform dangerous tasks and Hispanic teens the least likely $(\mathrm{p}=0.06)$. 
Table 6. Characteristics of teens who perform prohibited tasks versus those who do not

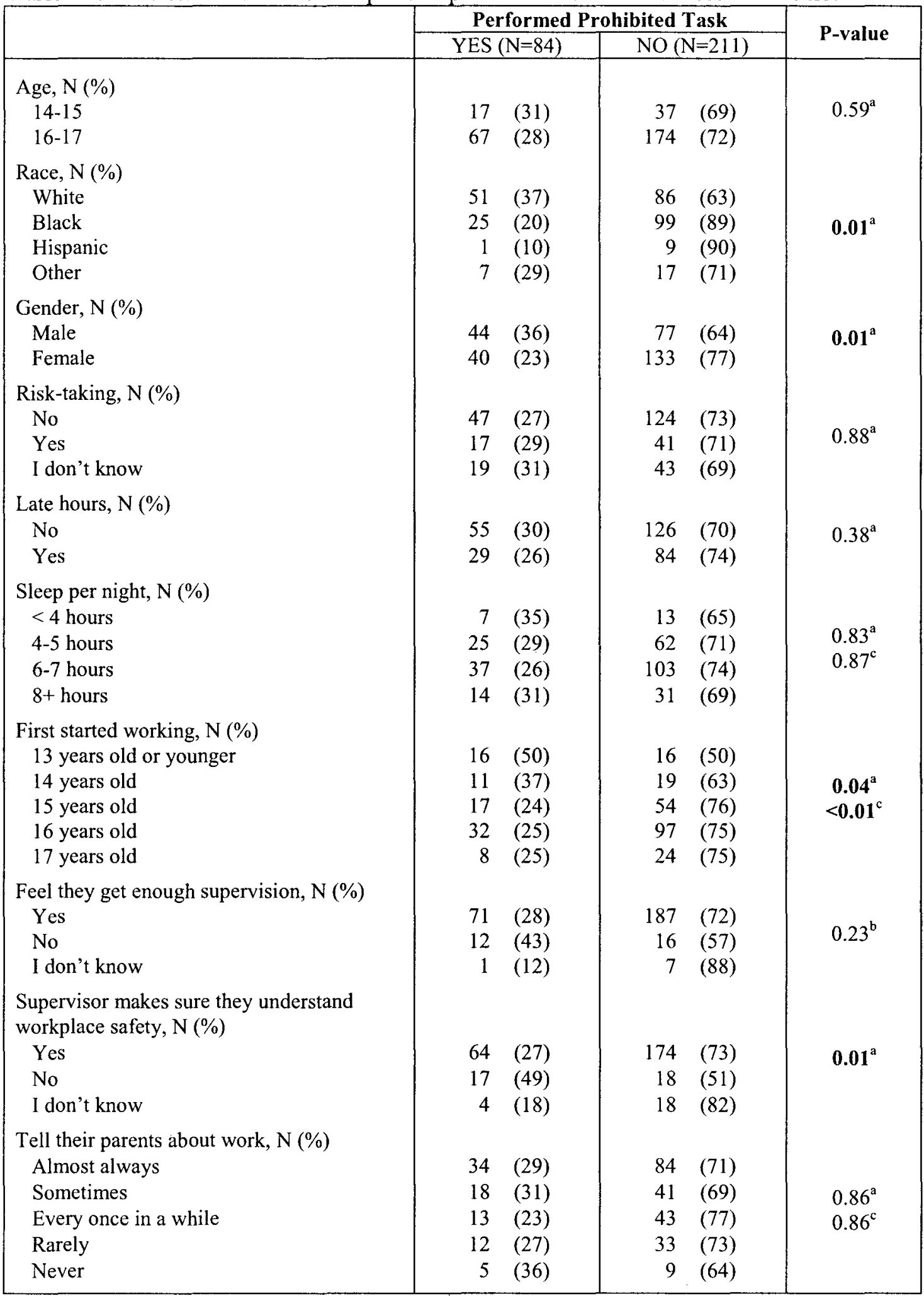

${ }^{a}$ Corresponds to chi-square test

${ }^{\mathrm{b}}$ Corresponds to Fisher's exact test

${ }^{c}$ Corresponds to Cochran-Armitage trend test 
Table 7. Characteristics of teens who perform dangerous tasks versus those who do not

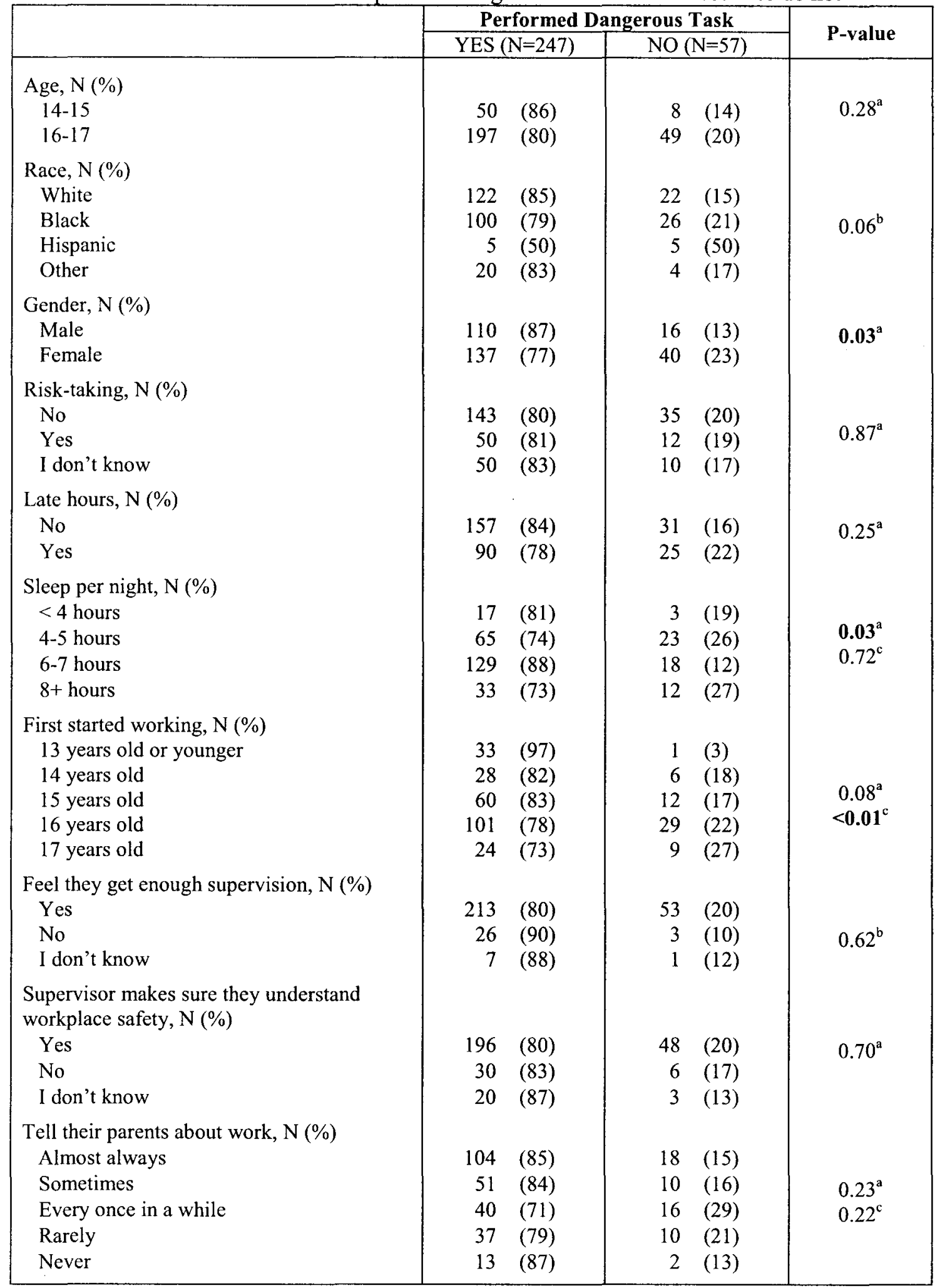

${ }^{a}$ Corresponds to chi-square test

${ }^{\mathrm{b}}$ Corresponds to Fisher's exact test

${ }^{\mathrm{c}}$ Corresponds to Cochran-Armitage trend test 
Among those who performed at least one dangerous task, demographic, behavioral, and work-related characteristics were examined with respect to the dangerous task score (Table 8). Median scores ranged from 2 to 4 tasks. Those who worked late hours were more likely to do more dangerous tasks at work, with a median score of four dangerous tasks, compared with those who did not work late hours, who had a median score of two dangerous tasks $(\mathrm{p}<0.01)$. Though not statistically significant at the 0.05 alpha level, there may be a relationship between feeling that one's supervisor makes sure they understand workplace safety and number of dangerous tasks that one performs at work. Teens who responded that they did not feel their supervisor made sure they understood workplace safety or that they didn't know performed more dangerous tasks than those who responded that they felt they did feel their supervisor made sure they understood workplace safety (median scores $=4$ vs. 2.5 , respectively; $p=0.07$ ). 
Table 8. Dangerous task scores associated with characteristics of working teens

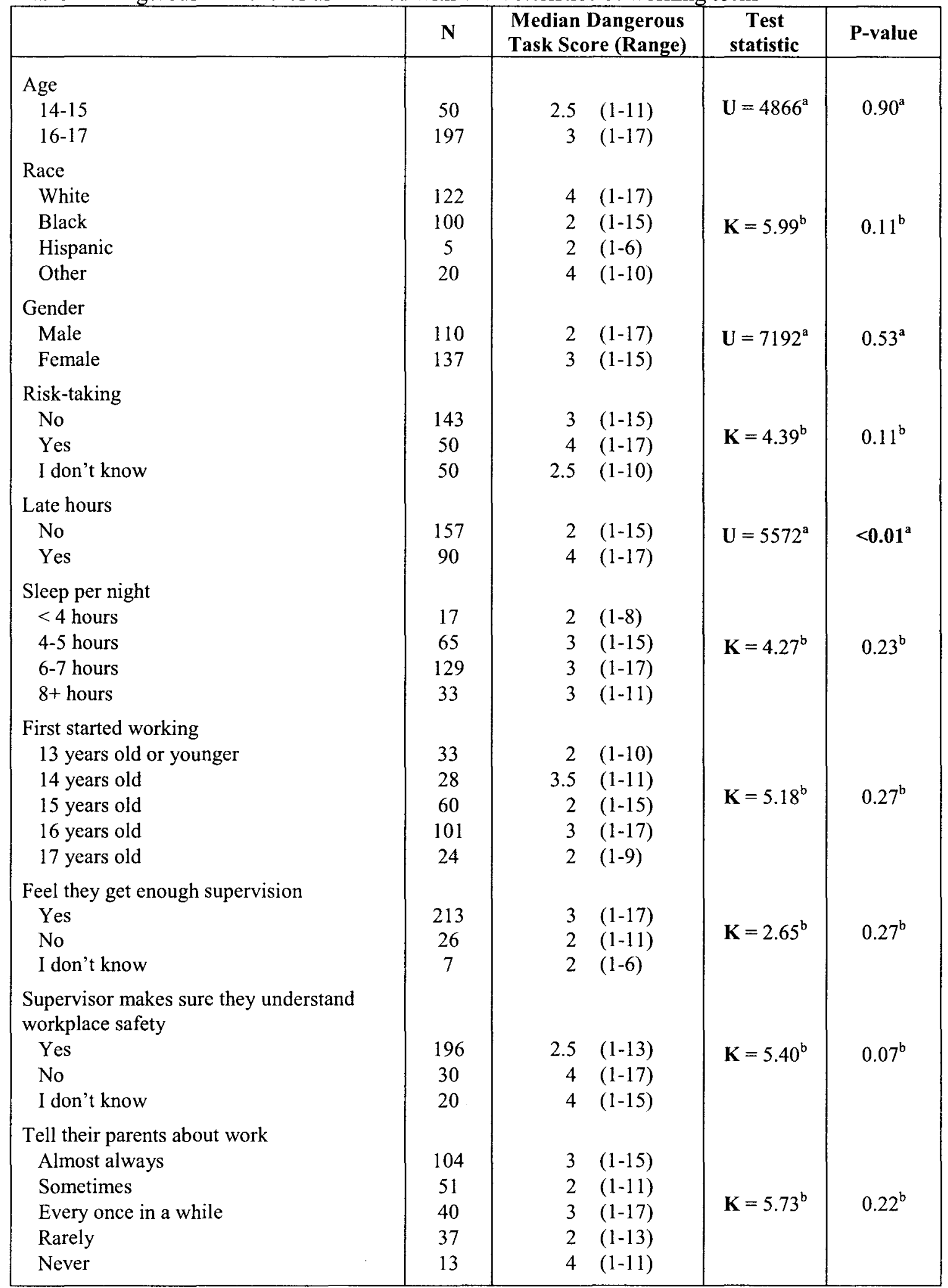

${ }^{a}$ Corresponds to Mann-Whitney-Wilcoxon test, using the normal approximation

${ }^{\mathrm{b}}$ Corresponds to Kruskal Wallis test 
d. Question 4: Are teens who perform hazardous tasks also more likely to perform prohibited tasks?

As shown in Table 9, workers who performed hazardous tasks were significantly more likely to perform prohibited tasks ( $\mathrm{p}<0.01$ ). Additionally, Table 10 shows that among teens who performed hazardous tasks, those who also reported performing prohibited tasks had significantly higher hazardous task scores than their counterparts (median scores $=4$ vs. 2 , respectively; $\mathrm{p}<0.01$ ).

Table 9. Relationship between hazardous task performance and prohibited task performance among all workers

\begin{tabular}{|c|c|c|c|}
\hline & \multicolumn{2}{|c|}{ Prohibited Task Performance } & \multirow{2}{*}{ P-value } \\
\hline & YES & $\mathrm{NO}$ & \\
\hline $\begin{array}{l}\text { Hazardous task performance, } \mathrm{N}(\%) \\
\text { Yes } \\
\text { No }\end{array}$ & $\begin{aligned} 75 & (33) \\
7 & (11)\end{aligned}$ & $\begin{aligned} 154 & (67) \\
57 & (89)\end{aligned}$ & $<0.01^{\mathrm{a}}$ \\
\hline
\end{tabular}

${ }^{a}$ Corresponds to chi-square test

Table 10. Hazardous task scores associated with prohibited task performance

\begin{tabular}{|l|c|r|c|c|}
\hline & N & $\begin{array}{c}\text { Median } \\
\text { Hazardous Task } \\
\text { Score (Range) }\end{array}$ & Test statistic & P-value \\
\hline $\begin{array}{l}\text { Prohibited task performance } \\
\text { Yes }\end{array}$ & 75 & $4(1-13)$ & $\mathbf{U}=3972^{\mathbf{a}}$ & $<\mathbf{. 0 1}^{\mathbf{a}}$ \\
No & 154 & $2(1-16)$ & \\
\hline
\end{tabular}

${ }^{a}$ Corresponds to Mann-Whitney-Wilcoxon test, using the normal approximation

\section{Specific Aim 2}

a. Question 1: Are teens who receive safety training less likely to perform hazardous, prohibited, or dangerous tasks than teens who do not receive safety training?

Seventy-seven percent $(n=247)$ of teens reported receiving safety training for their job. Based on chi-square analyses of teens who performed hazardous, prohibited and dangerous tasks, safety training was not associated with hazardous or dangerous task 
performance, and only had a borderline significant association with prohibited task performance (Table 11). Teens who did not receive safety training were more likely to perform prohibited tasks $-38 \%$ of those not trained reported at least one prohibited task, compared with only $26 \%$ of those who were trained $(\mathrm{p}=0.05)$.

Table 11. Hazardous, prohibited, and dangerous task performance and safety training

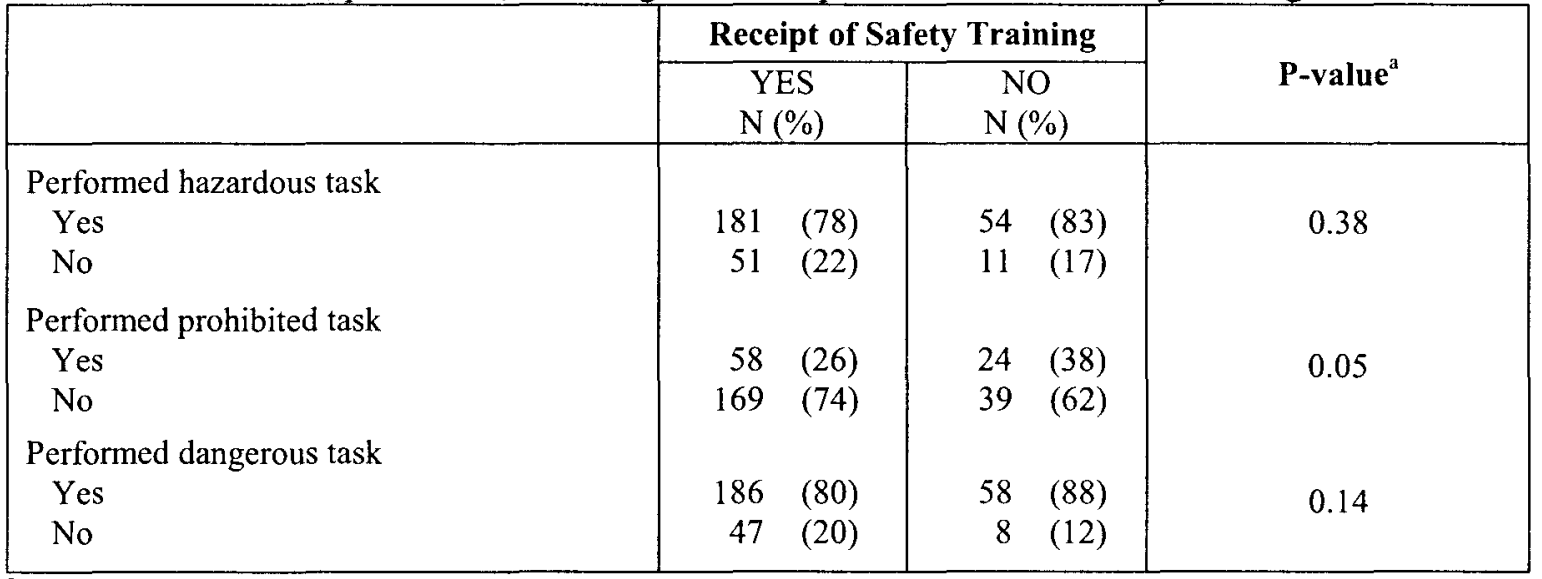

${ }^{\mathrm{a}}$ Corresponds to chi-square test

After adjusting for covariates in logistic regression, safety training was not a statistically significant predictor of performing hazardous, prohibited, or dangerous tasks (Table 12). However, the confidence intervals are wide and all of the crude and adjusted odds ratios are slightly elevated, which may suggest a relationship if the sample size were larger. Additionally, there may be other important covariates that were not included in this survey and were thus not accounted for in these analyses that could have an impact on these associations.

Receipt of safety training was not associated with a lower dangerous task score, as is shown in Table 13. 
Table 12. Logistic regression predicting hazardous, prohibited and dangerous task performance by the receipt of safety training

\begin{tabular}{|c|l|c|c|c|c|}
\hline Outcome & $\begin{array}{c}\text { Receipt of } \\
\text { Safety } \\
\text { Training }\end{array}$ & $\begin{array}{c}\text { Crude } \\
\text { Odds } \\
\text { Ratio }\end{array}$ & $\begin{array}{c}\mathbf{9 5 \%} \\
\text { Confidence } \\
\text { Interval }\end{array}$ & $\begin{array}{c}\text { Adjusted } \\
\text { Odds } \\
\text { Ratio** }\end{array}$ & $\begin{array}{c}\mathbf{9 5 \%} \\
\text { Confidence } \\
\text { Interval }\end{array}$ \\
\hline $\begin{array}{c}\text { Performed } \\
\text { hazardous task }\end{array}$ & $\begin{array}{l}\text { Safety training } \\
\text { No } \\
\text { Yes }\end{array}$ & $\begin{array}{c}1.38 \\
\text { Ref }\end{array}$ & $0.67-2.84$ & $\begin{array}{c}1.13^{\mathrm{a}} \\
\text { Ref }\end{array}$ & $0.48-2.65$ \\
\hline $\begin{array}{c}\text { Performed } \\
\text { prohibited task }\end{array}$ & $\begin{array}{l}\text { Safety training } \\
\text { No }\end{array}$ & $\begin{array}{l}1.79 \\
\text { Ref }\end{array}$ & $1.00-3.23$ & $\begin{array}{c}1.47^{\mathrm{b}} \\
\text { Ref }\end{array}$ & $0.79-2.74$ \\
\hline $\begin{array}{c}\text { Performed } \\
\text { dangerous task }\end{array}$ & $\begin{array}{l}\text { Safety training } \\
\text { No }\end{array}$ & $\begin{array}{l}1.83 \\
\text { Yef }\end{array}$ & $0.82-4.10$ & $\begin{array}{c}1.61^{\mathrm{c}} \\
\text { Ref }\end{array}$ & $0.61-4.22$ \\
\hline
\end{tabular}

${ }^{* *}$ Covariates selected for each model separately using the purposeful selection algorithm.

${ }^{a}$ Controlling for race, gender, sleep, and communication with parent/guardian

${ }^{b}$ Controlling for race, gender, and the feeling that supervisor makes sure they understand workplace safety

${ }^{c}$ Controlling for race, gender, sleep, communication with parent/guardian, and the feeling that one gets enough supervision

Table 13. Dangerous task score associated with receipt of safety training

\begin{tabular}{|l|c|c|c|c|}
\hline & N & $\begin{array}{c}\text { Median } \\
\text { Dangerous Task } \\
\text { Score (Range) }\end{array}$ & Test statistic & P-value \\
\hline $\begin{array}{l}\text { Safety training } \\
\text { Yes }\end{array}$ & 186 & $3(1-17)$ & $\mathbf{U}=5013$ & $0.41^{\mathrm{a}}$ \\
$\quad$ No & 58 & $3(1-15)$ & \\
\hline
\end{tabular}

${ }^{a}$ Corresponds to Mann-Whitney-Wilcoxon test, using the normal approximation

b. Question 2: Are teens who receive certain methods of safety training less likely to perform hazardous, prohibited, or dangerous tasks than teens who receive other methods of safety training?

In this part of the analysis, methods of training were examined to assess their impact on teens' performance of hazardous, prohibited and dangerous tasks at work. The results answering this question are broken down into sections addressing hazardous, prohibited, and dangerous task performance. 


\section{i. Hazardous task performance}

The results corresponding to chi-square analyses between safety training methods and hazardous task performance are shown in Table $14 .^{*}$ Complete results are located in the appendix. Teens trained by safety lectures and on-the-job safety demonstrations were more likely to perform hazardous tasks ( $92 \%$ and $88 \%$, respectively) than those trained with other methods ( $71 \%$ and $75 \%$, respectively; $p<0.01, p=0.04$, respectively). There was an increased proportion of hazardous task performance among those who were trained by safety posters and signs ( $86 \%)$, compared to those trained by other methods (78\%), though this relationship was not significant at 0.05 alpha level $(\mathrm{p}=0.08)$. There were no safety training methods that were associated with lower proportions of teens performing hazardous tasks.

Table 14. Relationships between safety training methods and hazardous task performance among all trained teens ${ }^{*}$

\begin{tabular}{|c|c|c|c|}
\hline \multirow{2}{*}{ Safety Training Method } & \multicolumn{2}{|c|}{ Performed Hazardous Task } & \multirow{2}{*}{ P-value } \\
\hline & YES $(N=179)$ & $\mathrm{NO}(\mathrm{N}=52)$ & \\
\hline Safety lectures, N (\%) & & & \\
\hline Yes & $70 \quad(92)$ & $6 \quad(8)$ & $<0.01$ \\
\hline No & $106 \quad(71)$ & $44 \quad(29)$ & \\
\hline Safety posters/signs, N (\% & & & \\
\hline Yes & $50 \quad(86)$ & $8 \quad(14)$ & 0.08 \\
\hline No & $111 \quad(78)$ & $32 \quad(22)$ & \\
\hline On-the-job safety demons & & & \\
\hline Yes & $50 \quad(88)$ & $7 \quad(12)$ & 0.04 \\
\hline No & $126 \quad(75)$ & $43 \quad(25)$ & \\
\hline
\end{tabular}

${ }^{\text {a }}$ Corresponds to chi-square test

\footnotetext{
* Abbreviated table shown, including only statistically significant and borderline significant results. Full table can be found in the appendix.
} 
After controlling for covariates, all three of these methods - safety lectures, safety posters and signs, and on-the-job safety demonstrations - were significantly associated with an increased likelihood of performing a hazardous task. The results of the logistic regression analyses are shown in Table 15.

Table 15. Logistic regression predicting hazardous task performance by the receipt of safety training methods among all trained teens

\begin{tabular}{|c|c|c|c|c|}
\hline Safety Training Method & $\begin{array}{l}\text { Crude } \\
\text { Odds } \\
\text { Ratio } \\
\end{array}$ & $\begin{array}{c}95 \% \\
\text { Confidence } \\
\text { Interval } \\
\end{array}$ & $\begin{array}{c}\text { Adjusted } \\
\text { Odds Ratio** }\end{array}$ & $\begin{array}{c}95 \% \\
\text { Confidence } \\
\text { Interval } \\
\end{array}$ \\
\hline $\begin{array}{l}\text { Safety lectures } \\
\text { Yes } \\
\text { No }\end{array}$ & $\begin{array}{l}4.92 \\
\text { Ref }\end{array}$ & $2.00-12.1$ & $\begin{array}{l}4.96 \\
\text { Ref }\end{array}$ & $1.91-12.9$ \\
\hline $\begin{array}{l}\text { Safety posters/signs } \\
\text { Yes } \\
\text { No }\end{array}$ & $\begin{array}{l}2.13 \\
\text { Ref }\end{array}$ & $0.94-4.85$ & $\begin{array}{l}2.66 \\
\text { Ref }\end{array}$ & $1.04-6.75$ \\
\hline $\begin{array}{l}\text { On-the-job safety demonstrations } \\
\text { Yes } \\
\text { No }\end{array}$ & $\begin{array}{l}2.49 \\
\text { Ref }\end{array}$ & $1.05-5.89$ & $\begin{array}{l}2.60 \\
\text { Ref }\end{array}$ & $1.04-6.50$ \\
\hline
\end{tabular}

**Controlled for race, gender, sleep, and communication with parent/guardian

\section{ii. Prohibited task performance}

Tables 16 and 17 present the results of the chi-square and logistic regression analyses used to determine relationships between safety training methods and prohibited task performance. ${ }^{*}$ Based on chi-square analyses, teens who were trained by safety lectures, practicing accident response, and posters/signs were more likely to perform a prohibited task than teens trained by other methods $(\mathrm{p}=0.03, \mathrm{p}=0.03$, and $\mathrm{p}=0.08$, respectively). Teens who received written safety quizzes were significantly less likely to perform prohibited tasks at work $(\mathrm{p}=0.02)$.

\footnotetext{
* Abbreviated table shown, including only statistically significant and borderline significant results. Full table can be found in the appendix.
} 
Table 16. Relationships between safety training methods and prohibited task performance among all trained teens ${ }^{*}$

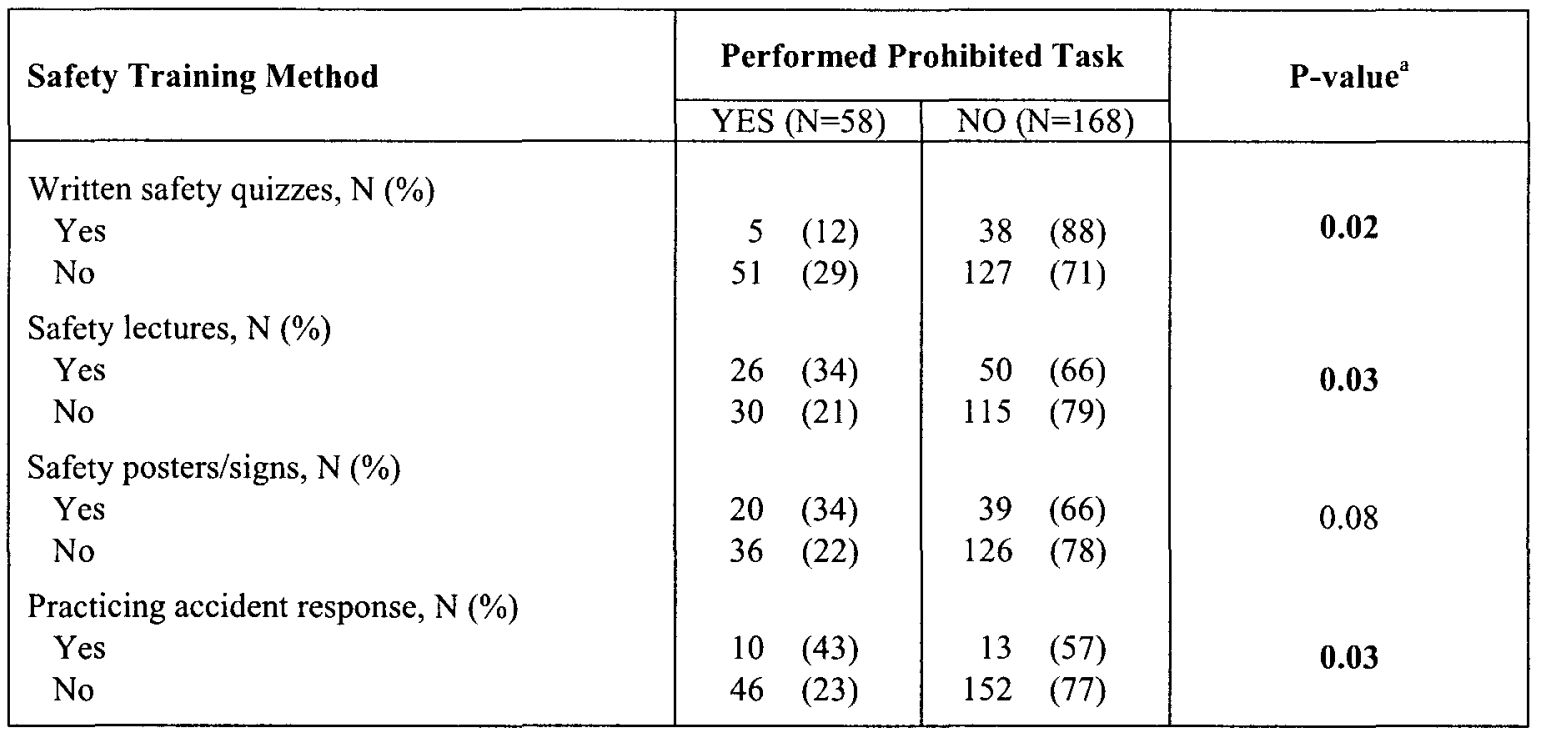

${ }^{\mathrm{a}}$ Corresponds to chi-square test

After controlling for covariates, teens who were trained by written safety quizzes had a decreased odds ratio of performing prohibited tasks compared with those trained by other methods $(\mathrm{AOR}=0.27,95 \% \mathrm{CI}: 0.09-0.81)$. Safety lectures, safety posters $/$ signs, and practicing accident response all had statistically significant elevated odds ratios after controlling for covariates $(\mathrm{AOR}=2.03$ [95\% CI: $1.06-3.87], 2.42[95 \% \mathrm{CI}: 1.16-3.87]$, and 3.21 [95\% CI: 1.21-8.45], respectively).

\footnotetext{
* Abbreviated table shown, including only statistically significant and borderline significant results. Full table can be found in the appendix.
} 
Table 17. Logistic regression predicting prohibited task performance by the receipt of safety training methods among all trained teens

\begin{tabular}{|c|c|c|c|c|}
\hline Safety Training Method & $\begin{array}{l}\text { Crude } \\
\text { Odds } \\
\text { Ratio } \\
\end{array}$ & $\begin{array}{c}95 \% \\
\text { Confidence } \\
\text { Interval } \\
\end{array}$ & $\begin{array}{c}\text { Adjusted } \\
\text { Odds } \\
\text { Ratio** } \\
\end{array}$ & $\begin{array}{c}95 \% \\
\text { Confidence } \\
\text { Interval } \\
\end{array}$ \\
\hline $\begin{array}{l}\text { Safety videos } \\
\text { Yes } \\
\text { No }\end{array}$ & $\begin{array}{l}0.58 \\
\operatorname{Ref}\end{array}$ & $0.32-1.06$ & $\begin{array}{l}0.64 \\
\text { Ref }\end{array}$ & $0.32-1.22$ \\
\hline $\begin{array}{l}\text { Written safety quizzes } \\
\text { Yes } \\
\text { No }\end{array}$ & $\begin{array}{c}\mathbf{0 . 3 2} \\
\text { Ref }\end{array}$ & $0.12-0.87$ & $\begin{array}{l}0.27 \\
\text { Ref }\end{array}$ & $0.09-0.81$ \\
\hline $\begin{array}{l}\text { Safety lectures } \\
\text { Yes } \\
\text { No }\end{array}$ & $\begin{array}{l}1.92 \\
\text { Ref }\end{array}$ & $1.04-3.54$ & $\begin{array}{l}2.03 \\
\text { Ref }\end{array}$ & $1.06-3.87$ \\
\hline $\begin{array}{l}\text { Safety posters/signs } \\
\text { Yes } \\
\text { No }\end{array}$ & $\begin{array}{l}1.74 \\
\operatorname{Ref}\end{array}$ & $0.91-3.33$ & $\begin{array}{l}2.42 \\
\text { Ref }\end{array}$ & $1.16-5.04$ \\
\hline $\begin{array}{l}\text { Practicing accident response } \\
\text { Yes } \\
\text { No }\end{array}$ & $\begin{array}{c}2.48 \\
\text { Ref }\end{array}$ & $1.02-6.02$ & $\begin{array}{l}3.21 \\
\text { Ref }\end{array}$ & $1.21-8.45$ \\
\hline
\end{tabular}

${ }^{* *}$ Controlling for race, gender, feeling that their supervisor makes sure they understand workplace safety, and communication with parent/guardian

\section{iii. Dangerous task performance}

Table 18 shows results from chi-square analyses of safety training methods with dangerous tasks as the outcome. ${ }^{*}$ Safety videos were significantly associated with a lower proportion of dangerous task performance $(\mathrm{p}=0.04)$. Computer safety quizzes were also associated with a lower proportion, though not statistically significant $(\mathrm{p}=0.07)$. Safety lectures, posters and signs, and on-the-job demonstrations were associated with a higher proportion of dangerous task performance $(\mathrm{p}<0.01, \mathrm{p}=0.02, \mathrm{p}=0.07$, respectively).

\footnotetext{
*Abbreviated table shown, including only statistically significant and borderline significant results. Full table can be found in the appendix.
} 
Table 18. Relationships between safety training methods and dangerous task performance among all trained teens ${ }^{*}$

\begin{tabular}{|c|c|c|c|}
\hline \multirow{2}{*}{ Safety Training Method } & \multicolumn{2}{|c|}{ Performed Dangerous Task } & \multirow{2}{*}{ P-value ${ }^{a}$} \\
\hline & $\mathrm{YES}(\mathrm{N}=184)$ & $\mathrm{NO}(\mathrm{N}=48)$ & \\
\hline \multicolumn{4}{|l|}{ Safety videos, N (\%) } \\
\hline Yes & $95 \quad(75)$ & $32 \quad(25)$ & 0.04 \\
\hline No & $86 \quad(86)$ & $14 \quad(14)$ & \\
\hline \multicolumn{4}{|l|}{ Safety lectures, N $(\%)$} \\
\hline Yes & $72 \quad(94)$ & $5 \quad(6)$ & $<0.01$ \\
\hline No & $109 \quad(73)$ & $41 \quad(27)$ & \\
\hline \multicolumn{4}{|l|}{ Safety posters/signs, N (\%) } \\
\hline Yes & $53 \quad(90)$ & $6 \quad(10)$ & 0.02 \\
\hline No & $128 \quad(76)$ & $40 \quad(24)$ & \\
\hline \multicolumn{4}{|c|}{ Computer safety quizzes, $\mathrm{N}(\%)$} \\
\hline Yes & $21 \quad(68)$ & $10 \quad(32)$ & 0.07 \\
\hline No & $160 \quad(82)$ & $36 \quad(18)$ & \\
\hline \multicolumn{4}{|c|}{ On-the-job safety demonstrations, N (\%) } \\
\hline Yes & $51 \quad(88)$ & $7 \quad(12)$ & 0.07 \\
\hline No & $130 \quad(77)$ & $39 \quad(23)$ & \\
\hline
\end{tabular}

${ }^{a}$ Corresponds to chi-square test

Results from univariable and multivariable logistic regression models are shown in Table 19. After controlling for covariates, teens trained by safety videos had a decreased adjusted odds ratio (AOR) for dangerous task performance, with borderline significance $(\mathrm{AOR}=0.53,95 \% \mathrm{CI}: 0.25-1.10)$. Safety lectures and posters/signs were associated with an elevated AOR for performing dangerous tasks $(\mathrm{AOR}=6.04[95 \% \mathrm{CI}$ : 2.18-16.7], $\mathrm{AOR}=3.13$ [95\% CI: 1.17-8.36], respectively) and safety demonstrations also were associated with an elevated AOR, with borderline significance (AOR $=2.49,95 \%$ $\mathrm{Cl}: 1.00-6.19)$.

\footnotetext{
* Abbreviated table shown, including only statistically significant and borderline significant results. Full table can be found in the appendix.
} 
Table 19. Logistic regression predicting dangerous task performance by the receipt of safety training methods among all trained teens *

\begin{tabular}{|c|c|c|c|c|}
\hline Safety Training Method & $\begin{array}{l}\text { Crude } \\
\text { Odds } \\
\text { Ratio }\end{array}$ & $\begin{array}{c}95 \% \\
\text { Confidence } \\
\text { Interval }\end{array}$ & $\begin{array}{c}\text { Adjusted } \\
\text { Odds } \\
\text { Ratio** }\end{array}$ & $\begin{array}{c}\mathbf{9 5 \%} \\
\text { Confidence } \\
\text { Interval } \\
\end{array}$ \\
\hline $\begin{array}{l}\text { Safety videos } \\
\text { Yes } \\
\text { No }\end{array}$ & $\begin{array}{l}0.53 \\
\operatorname{Ref}\end{array}$ & $0.27-1.04$ & $\begin{array}{l}0.53 \\
\text { Ref }\end{array}$ & $0.25-1.10$ \\
\hline $\begin{array}{l}\text { Safety lectures } \\
\text { Yes } \\
\text { No }\end{array}$ & $\begin{array}{c}\mathbf{5 . 5 3} \\
\text { Ref }\end{array}$ & $2.09-14.6$ & $\begin{array}{c}\mathbf{6 . 0 4} \\
\text { Ref }\end{array}$ & 2.18-16.7 \\
\hline $\begin{array}{l}\text { Safety posters/signs } \\
\text { Yes } \\
\text { No }\end{array}$ & $\begin{array}{c}2.83 \\
\text { Ref }\end{array}$ & $1.14-7.06$ & $\begin{array}{c}3.13 \\
\text { Ref }\end{array}$ & $1.17-8.36$ \\
\hline $\begin{array}{l}\text { On-the-job safety demonstrations } \\
\text { Yes } \\
\text { No }\end{array}$ & $\begin{array}{c}2.25 \\
\operatorname{Ref}\end{array}$ & $0.95-5.33$ & $\begin{array}{c}2.49 \\
\text { Ref }\end{array}$ & $1.00-6.19$ \\
\hline
\end{tabular}

** Controlled for race, gender, sleep, and communication with parent/guardian

Mann-Whitney-Wilcoxon tests were used to determine whether safety training methods were associated with performance of a higher number of dangerous tasks. Table 20 shows the one statistically significant relationship between safety training methods and dangerous task scores. ${ }^{*}$ Teens who were trained with on-the-job safety demonstrations were more likely to perform more dangerous tasks, with a median of four dangerous tasks, than their counterparts trained with different methods, who reported a median of two dangerous tasks $(\mathrm{p}<0.01)$.

Table 20. Differences in dangerous task scores between recipients of specific methods of safety training, among all trained teens who performed at least one dangerous task ${ }^{*}$

\begin{tabular}{|c|c|c|c|c|}
\hline Safety Training Method & $\mathbf{N}$ & $\begin{array}{c}\text { Median } \\
\text { Dangerous Task } \\
\text { Score (Range) } \\
\end{array}$ & Test statistic ${ }^{a}$ & P-value ${ }^{a}$ \\
\hline $\begin{array}{l}\text { On-the-job safety demonstrations } \\
\text { Yes } \\
\text { No }\end{array}$ & $\begin{array}{c}51 \\
130\end{array}$ & $\begin{array}{ll}4 & (1-13) \\
2 & (1-17)\end{array}$ & $\mathbf{U}=2.4 \times 10^{3}$ & $<0.01$ \\
\hline
\end{tabular}

${ }^{a}$ Corresponds to Mann-Whitney-Wilcoxon test, using the normal approximation

\footnotetext{
* Abbreviated table shown, including only statistically significant and borderline significant results. Full table can be found in the appendix.
} 
iv. Multiple methods of safety training and hazardous, prohibited, and dangerous task performance

To analyze the effect of multiple methods of safety training, the distributions of the safety training method scores were compared among those who performed hazardous tasks and those who did not, those who performed prohibited tasks and those who did not, and those who performed dangerous tasks and those who did not (Table 21). ${ }^{*}$ No statistically significant relationships emerged from these analyses.

Table 21. Differences in safety training method scores of those who performed hazardous, prohibited, and dangerous tasks*

\begin{tabular}{|c|c|c|c|c|}
\hline$-1+5=$ & $\mathbf{N}$ & $\begin{array}{l}\text { Median Safety Training } \\
\text { Method Score (Range) }\end{array}$ & Test statistic ${ }^{a}$ & P-value ${ }^{a}$ \\
\hline $\begin{array}{l}\text { Performed hazardous task } \\
\text { Yes } \\
\text { No }\end{array}$ & $\begin{array}{c}176 \\
50\end{array}$ & $\begin{array}{ll}2 & (1-8) \\
1 & (1-6)\end{array}$ & $\mathbf{U}=3754$ & 0.09 \\
\hline $\begin{array}{l}\text { Performed prohibited task } \\
\text { Yes } \\
\text { No }\end{array}$ & $\begin{array}{c}56 \\
165\end{array}$ & $\begin{array}{ll}2 & (1-8) \\
2 & (1-8)\end{array}$ & $\mathbf{U}=4586$ & 0.93 \\
\hline $\begin{array}{l}\text { Performed dangerous task } \\
\text { Yes } \\
\text { No }\end{array}$ & $\begin{array}{c}181 \\
46\end{array}$ & $\begin{array}{ll}2 & (1-8) \\
1 & (1-6)\end{array}$ & $\mathbf{U}=3652$ & 0.17 \\
\hline
\end{tabular}

${ }^{a}$ Corresponds to Mann-Whitney-Wilcoxon test, using the normal approximation

Table 22 provides a summary of all the findings from specific aim 2, question 2.

\footnotetext{
* Abbreviated table shown, including only statistically significant and borderline significant results. Full table can be found in the appendix.
} 
Table 22. Summary of results from analyses answering specific aim 2, question 2

${ }^{a}$ Corresponds to a statistically significant positive association

${ }^{\mathrm{b}}$ Corresponds to a statistically significant negative association

${ }^{\mathrm{c}}$ Corresponds to a borderline statistically significant positive association

\begin{tabular}{|c|c|c|c|c|c|c|c|c|}
\hline $\begin{array}{l}\text { Safety Training } \\
\text { Method }\end{array}$ & $\mathbf{N}$ & $\begin{array}{c}\text { Performed } \\
\text { Hazardous } \\
\text { Task } \\
\text { (\% trained with } \\
\text { this method vs. } \\
\% \text { others) }\end{array}$ & $\begin{array}{l}\text { AOR for } \\
\text { Performing } \\
\text { Hazardous } \\
\text { Task } \\
(95 \% \mathrm{CI})\end{array}$ & $\begin{array}{c}\text { Performed } \\
\text { Prohibited Task } \\
\text { (\% trained with } \\
\text { this method vs. } \\
\% \text { others) }\end{array}$ & $\begin{array}{c}\text { AOR for } \\
\text { Performing } \\
\text { Prohibited } \\
\text { Task } \\
\text { (95\% CI) }\end{array}$ & $\begin{array}{c}\text { Performed } \\
\text { Dangerous Task } \\
\text { (\% trained with } \\
\text { this method vs. } \\
\% \text { others) }\end{array}$ & $\begin{array}{l}\text { AOR for } \\
\text { Performing } \\
\text { Dangerous } \\
\text { Task } \\
(95 \% \text { CI })\end{array}$ & $\begin{array}{c}\text { Median } \\
\text { Dangerous Task } \\
\text { Score } \\
\text { (of those trained } \\
\text { with this method } \\
\text { vs. others) }\end{array}$ \\
\hline Videos & 126 & $\begin{array}{c}75 \% \text { vs. } 82 \% \\
\text { p }=0.18\end{array}$ & $\begin{array}{c}0.60 \\
(0.29-1.24)\end{array}$ & $\begin{array}{c}21 \% \text { vs. } 31 \% \\
\text { p }=0.09\end{array}$ & $\begin{array}{c}0.64 \\
(0.32-1.22)\end{array}$ & $\begin{array}{c}75 \% \text { vs. } 86 \% \\
\text { p }=0.04^{b}\end{array}$ & $\begin{array}{c}0.53^{\mathrm{d}} \\
(0.25-1.10)\end{array}$ & $\begin{array}{l}2 \text { vs. } 3 \\
p=0.94\end{array}$ \\
\hline Lectures & 76 & $\begin{array}{c}92 \% \text { vs. } 71 \% \\
\text { p }<0.01^{2}\end{array}$ & $\begin{array}{c}4.96^{\mathrm{a}} \\
(1.91-12.90)\end{array}$ & $\begin{array}{c}34 \% \text { vs. } 21 \% \\
\text { p }=0.03^{\mathrm{a}}\end{array}$ & $\begin{array}{c}2.03^{2} \\
(1.06-3.87)\end{array}$ & $\begin{array}{c}94 \% \text { vs. } 73 \% \\
\text { p }<0.01^{2}\end{array}$ & $\begin{array}{c}6.04^{\mathrm{a}} \\
(2.18-16.7)\end{array}$ & $\begin{array}{l}\text { v vs. } 2 \\
p=0.14\end{array}$ \\
\hline Posters/signs & 58 & $\begin{array}{c}86 \% \text { vs. } 78 \% \\
p=0.08^{\mathrm{c}}\end{array}$ & $\begin{array}{c}2.66^{\mathrm{a}} \\
(1.04-6.75) \\
\end{array}$ & $\begin{array}{c}34 \% \text { vs. } 22 \% \\
\mathrm{p}=0.08^{\mathrm{c}}\end{array}$ & $\begin{array}{c}2.42^{2} \\
(1.16-5.04) \\
\end{array}$ & $\begin{array}{c}90 \% \text { vs. } 76 \% \\
p=0.02^{\mathrm{a}}\end{array}$ & $\begin{array}{c}3.13^{\mathrm{a}} \\
(1.17-8.36) \\
\end{array}$ & $\begin{array}{l}3 \text { vs. } 2 \\
p=0.19\end{array}$ \\
\hline Computer quizzes & 30 & $\begin{array}{c}67 \% \text { vs. } 80 \% \\
p=0.11\end{array}$ & $\begin{array}{c}0.58 \\
(0.22-1.56) \\
\end{array}$ & $\begin{array}{c}17 \% \text { vs. } 27 \% \\
\mathrm{p}=0.24\end{array}$ & $\begin{array}{c}0.87 \\
(0.29-2.60) \\
\end{array}$ & $\begin{array}{c}68 \% \text { vs. } 82 \% \\
p=0.07^{\mathrm{d}}\end{array}$ & $\begin{array}{c}0.58 \\
(0.22-1.55) \\
\end{array}$ & $\begin{array}{l}4 \text { vs. } 2.5 \\
p=0.42\end{array}$ \\
\hline Reading materials & 37 & $\begin{array}{c}76 \% \text { vs. } 78 \% \\
\text { p }=0.72\end{array}$ & $\begin{array}{c}0.90 \\
(0.35-2.27)\end{array}$ & $\begin{array}{c}17 \% \text { vs. } 27 \% \\
p=0.19\end{array}$ & $\begin{array}{c}0.63 \\
(0.24-1.71)\end{array}$ & $\begin{array}{c}76 \% \text { vs. } 81 \% \\
p=0.50\end{array}$ & $\begin{array}{c}0.79 \\
(0.31-2.00)\end{array}$ & $\begin{array}{l}3.4 \text { vs. } 2 \\
p=0.11\end{array}$ \\
\hline $\begin{array}{l}\text { Practicing accident } \\
\text { response }\end{array}$ & 23 & $\begin{array}{c}78 \% \text { vs. } 78 \% \\
\text { p }=0.96\end{array}$ & $\begin{array}{c}0.93 \\
(0.29-2.97)\end{array}$ & $\begin{array}{c}43 \% \text { vs. } 23 \% \\
\text { p }=0.03^{\mathrm{a}}\end{array}$ & $\begin{array}{c}3.21^{\mathrm{a}} \\
(1.21-8.45)\end{array}$ & $\begin{array}{c}83 \% \text { vs. } 79 \% \\
p=0.79\end{array}$ & $\begin{array}{c}1.38 \\
(0.40-4.69)\end{array}$ & $\begin{array}{l}2 \text { vs. } 3 \\
p=0.54\end{array}$ \\
\hline Other & 11 & $\begin{array}{c}64 \% \text { vs. } 79 \% \\
p=0.26\end{array}$ & $\begin{array}{c}0.35 \\
(0.07-1.74)\end{array}$ & $\begin{array}{c}27 \% \text { vs. } 25 \% \\
p=1.00\end{array}$ & $\begin{array}{c}1.12 \\
(0.25-4.97)\end{array}$ & $\begin{array}{c}64 \% \text { vs. } 81 \% \\
p=0.24\end{array}$ & $\begin{array}{c}0.35 \\
(0.07-1.71)\end{array}$ & $\begin{array}{l}4 \text { vs. } 3 \\
p=0.57\end{array}$ \\
\hline
\end{tabular}

${ }^{\mathrm{d}}$ Corresponds to a borderline statistically significant negative association 
c. Question 3: Are teens who learn certain lessons in safety training less likely to perform hazardous, prohibited, or dangerous tasks than teens who learn other lessons?

i. Hazardous task performance

When evaluating the lessons teens learned in safety training, one statistically significant association emerged with the likelihood of performing hazardous tasks. Table 23 shows the data corresponding to this relationship ${ }^{*}$ - those who were trained what chemicals were at their job were more likely to perform a hazardous task $(\mathrm{p}=0.03)$.

Table 23. Relationships between safety training lessons and hazardous task performance among all trained teens ${ }^{*}$

\begin{tabular}{|c|c|c|c|}
\hline \multirow{2}{*}{ Safety Training Lesson } & \multicolumn{2}{|c|}{ Performed Hazardous Task } & \multirow{2}{*}{ P-value ${ }^{\mathrm{a}}$} \\
\hline & $\mathrm{YES}(\mathrm{N}=179)$ & $\mathrm{NO}(\mathrm{N}=52)$ & \\
\hline What chemicals are at my job, $\mathrm{N}(\%)$ & & & \\
\hline Yes & $46 \quad(88)$ & $6 \quad(12)$ & 0.03 \\
\hline No & 133 (74) & $46 \quad(26)$ & \\
\hline
\end{tabular}

${ }^{a}$ Corresponds to chi-square test

Univariable and multivariable logistic regression (results shown in Table $24^{*}$ ) showed this same lesson - what chemicals are at my job - as the only significant predictor of performing hazardous tasks at work. After adjusting for covariates, those who were taught what chemicals were at their job were nearly 3 times as likely to perform a hazardous task at work than those not given this lesson in their safety training $(\mathrm{AOR}=2.93,95 \% \mathrm{Cl}: 1.07-8.01)$.

\footnotetext{
* Abbreviated table shown, including only statistically significant and borderline significant results. Full table can be found in the appendix.
} 
Table 24. Logistic regression predicting hazardous task performance by the receipt of safety training lessons among all trained teens ${ }^{*}$

\begin{tabular}{|l|c|c|c|c|}
\hline Safety Training Lesson & $\begin{array}{c}\text { Crude } \\
\text { Odds } \\
\text { Ratio }\end{array}$ & $\begin{array}{c}\mathbf{9 5 \%} \\
\text { Confidence } \\
\text { Interval }\end{array}$ & $\begin{array}{c}\text { Adjusted } \\
\text { Odds } \\
\text { Ratio** }\end{array}$ & $\begin{array}{c}95 \% \\
\text { Confidence } \\
\text { Interval }\end{array}$ \\
\hline $\begin{array}{l}\text { What chemicals are at my job } \\
\text { Yes } \\
\text { No }\end{array}$ & $\begin{array}{c}2.65 \\
\text { Ref }\end{array}$ & $1.06-6.62$ & $\begin{array}{c}2.93 \\
\text { Ref }\end{array}$ & $1.07-8.01$ \\
\hline
\end{tabular}

${ }^{* *}$ Controlled for race, gender, sleep, and communication with parent/guardian

\section{ii. Prohibited task performance}

With prohibited tasks as the outcome, those taught how to operate the equipment at their jobs and those taught safe driving techniques were more likely to perform prohibited tasks $(\mathrm{p}<0.01$ and $\mathrm{p}<0.01)$. Results from these analyses are shown in Table $25{ }^{*}$

Table 25. Relationships between safety training lessons and prohibited task performance among all trained teens ${ }^{*}$

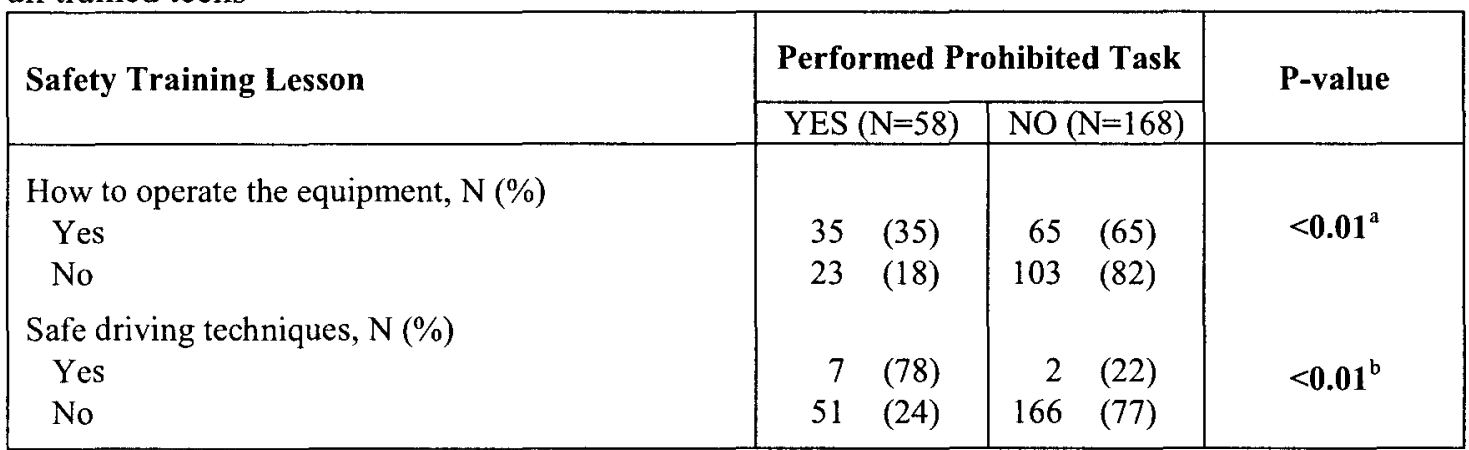

${ }^{a}$ Corresponds to chi-square test

${ }^{\mathrm{b}}$ Corresponds to Fisher's exact test

Table 26 shows that these same lessons taught in safety training are significant predictors of prohibited task performance after adjusting for covariates, with those taught

\footnotetext{
${ }^{*}$ Abbreviated table shown, including only statistically significant and borderline significant results. Full table can be found in the appendix.
} 
how to operate equipment over twice as likely to perform prohibited tasks, and those taught safe driving techniques nearly 11 times more likely to perform prohibited tasks.

Table 26. Logistic regression predicting prohibited task performance by the receipt of safety training lessons among all trained teens

\begin{tabular}{|l|c|c|c|c|}
\hline Safety Training Lesson & $\begin{array}{c}\text { Crude } \\
\text { Odds } \\
\text { Ratio }\end{array}$ & $\begin{array}{c}\mathbf{9 5 \%} \\
\text { Confidence } \\
\text { Interval }\end{array}$ & $\begin{array}{c}\text { Adjusted } \\
\text { Odds } \\
\text { Ratio** }\end{array}$ & $\begin{array}{c}\mathbf{9 5 \%} \\
\text { Confidence } \\
\text { Interval }\end{array}$ \\
\hline How to operate the equipment & & & & \\
$\quad$ Yes & 2.41 & $1.31-4.44$ & 2.34 & $1.22-4.50$ \\
No & Ref & & Ref & \\
Safe driving techniques & 11.4 & $2.29-56.6$ & 10.7 & $\mathbf{2 . 0 5 - 5 6 . 0}$ \\
Yes & Ref & & Ref & \\
No & & & \\
\hline
\end{tabular}

**Controlled for race, gender, communication with parent/guardian and the feeling that their supervisor makes sure they understand workplace safety.

\section{iii. Lessons in safety training and dangerous task performance}

With dangerous tasks as the outcome, only one lesson - what chemicals are at my job - had a borderline significant association (Table 27).

Table 27. Relationships between safety training lessons and dangerous task performance among all trained teens ${ }^{*}$

\begin{tabular}{|c|c|c|c|}
\hline \multirow{2}{*}{ Safety Training Lesson } & \multicolumn{2}{|c|}{ Performed Dangerous Task } & \multirow{2}{*}{ P-value } \\
\hline & $\mathrm{YES}(\mathrm{N}=184)$ & $\mathrm{NO}(\mathrm{N}=48)$ & \\
\hline What chemicals are at my job, $N(\%)$ & & & \\
\hline Yes & $46 \quad(88)$ & $6 \quad(12)$ & $0.06^{\mathrm{a}}$ \\
\hline No & $138 \quad(77)$ & $42 \quad(23)$ & \\
\hline
\end{tabular}

${ }^{a}$ Corresponds to chi-square test

Table 28 shows the borderline significant predictors of performing dangerous tasks at work, as calculated from logistic regression. ${ }^{*}$ None of the safety training lessons were statistically significant predictors. Being taught what chemicals were at one's job was a borderline significant predictor of dangerous task performance in a univariable

\footnotetext{
* Abbreviated table shown, including only statistically significant and borderline significant results. Full table can be found in the appendix.
} 
model and after adjusting for covariates. Being taught child labor laws, after adjusting for covariates, was found to be a borderline predictor of dangerous task performance as well. Both of these adjusted odds ratios are elevated, indicating that a higher percentage of teens who were taught these lessons performed dangerous tasks compared to teens trained with other lessons.

Table 28. Logistic regression predicting dangerous task performance by the receipt of safety training lessons among all trained teens

\begin{tabular}{|l|c|c|c|c|}
\hline Safety Training Lesson & $\begin{array}{c}\text { Crude } \\
\text { Odds } \\
\text { Ratio }\end{array}$ & $\begin{array}{c}\mathbf{9 5 \%} \\
\text { Confidence } \\
\text { Interval }\end{array}$ & $\begin{array}{c}\text { Adjusted } \\
\text { Odds Ratio** }\end{array}$ & $\begin{array}{c}\mathbf{9 5 \%} \\
\text { Confidence } \\
\text { Interval }\end{array}$ \\
\hline Child labor laws & & & & \\
$\quad$ Yes & 2.24 & $0.83-6.04$ & 2.83 & $0.96-8.30$ \\
No & Ref & & Ref & \\
What chemicals are at my job & 2.33 & $0.93-5.84$ & 2.63 & $0.97-7.14$ \\
Yes & Ref & & Ref & \\
No & & & \\
\hline
\end{tabular}

${ }^{* *}$ Controlled for race, gender, sleep, and communication with parent/guardian

Though only a few individual relationships emerged between lessons taught in safety training and likelihood to perform hazardous, prohibited, or dangerous tasks, a number of lessons taught in safety training were associated with the number of dangerous tasks that teens performed. Table 29 shows the relationships that were statistically significant or borderline significant. ${ }^{*}$ The lessons associated with higher dangerous task scores were how to read warning labels, what personal protective equipment I need, first aid skills/what to do when someone is injured, what chemicals are at my job, how to operate the equipment, safe lifting practices, safe climbing practices/how to prevent slips,

\footnotetext{
* Abbreviated table shown, including only statistically significant and borderline significant results. Full table can be found in the appendix.
} 
trips, and falls, what job tasks I should NOT do, and safe driving techniques. There were no lessons associated with lower dangerous task scores.

Table 29. Differences in dangerous task scores between recipients of lessons of safety training, among all trained teens who performed dangerous tasks ${ }^{*}$

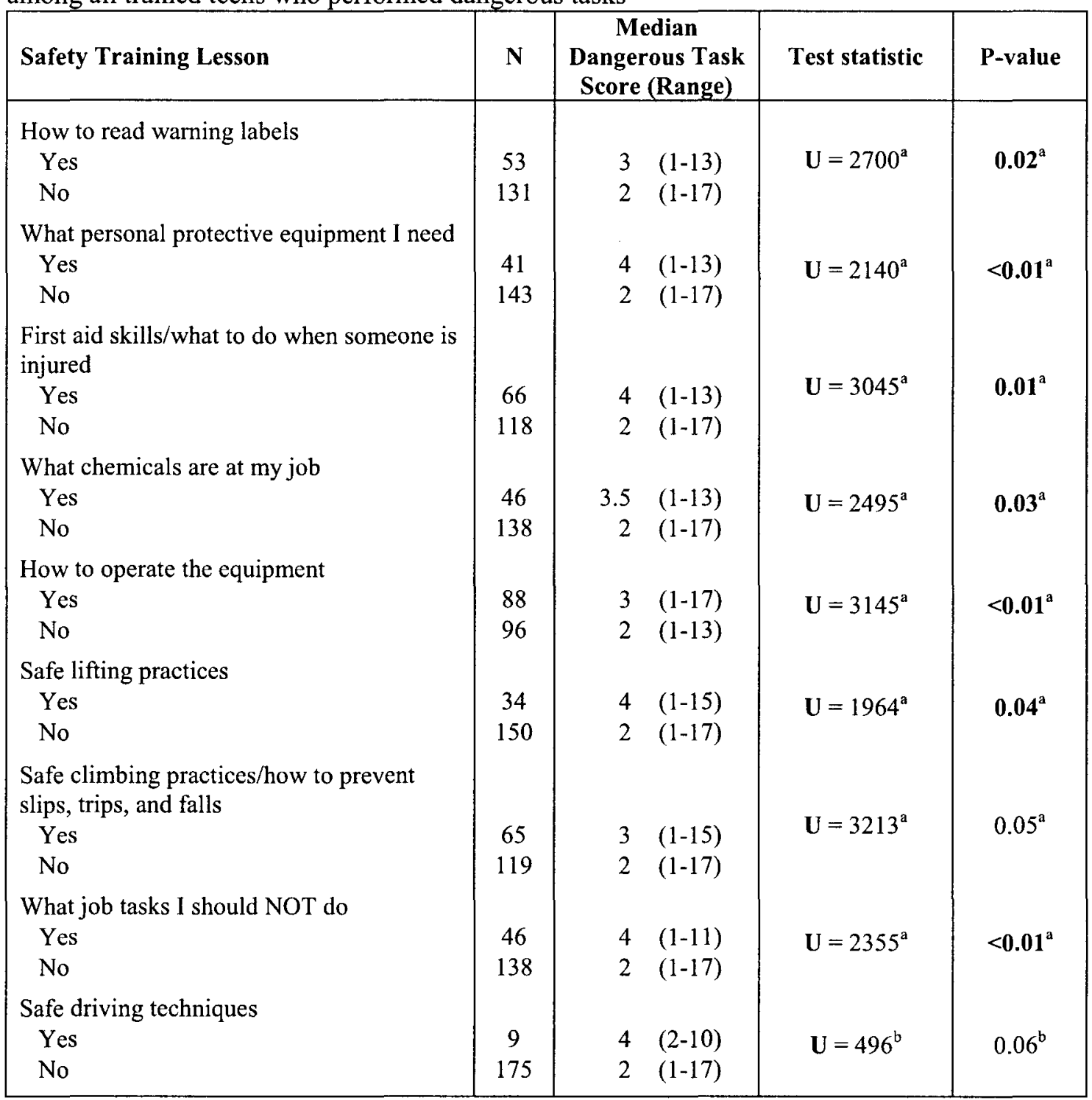

${ }^{a}$ Corresponds to Mann-Whitney-Wilcoxon test, using the normal approximation

${ }^{b}$ Corresponds to Mann-Whitney-Wilcoxon test, using the $t$ approximation

Table 30 summarizes the findings from question 3 in specific aim 2.

\footnotetext{
* Abbreviated table shown, including only statistically significant and borderline significant results. Full table can be found in the appendix.
} 
d. Question 4: Are teens who receive safety training for a longer length of time less likely to perform hazardous, prohibited, or dangerous tasks than teens who receive safety training for a shorter length of time?

The effect of the length of safety training on teens' likelihood of performing hazardous, prohibited, or dangerous tasks was evaluated. Table 31 shows the results from Cochran-Armitage trend tests, where a linear trend was present among those who performed hazardous and dangerous tasks, but not those who performed prohibited tasks. Those who had longer safety training were less likely to perform hazardous and dangerous tasks ( $\mathrm{p}<0.01$ and $\mathrm{p}<0.01$, respectively).

Table 32 shows the results of univariable and multivariable logistic regression models. After controlling for covariates, longer safety training was associated with a decreased likelihood of performing hazardous and dangerous tasks, but not prohibited tasks. 
Table 30. Summary of results from analyses answering specific aim 2, question 3

\begin{tabular}{|c|c|c|c|c|c|c|c|c|}
\hline $\begin{array}{l}\text { Safety Training } \\
\text { Lesson }\end{array}$ & $\mathbf{N}$ & $\begin{array}{l}\text { Performed } \\
\text { Hazardous Task } \\
\text { (\% trained with } \\
\text { this method, \% } \\
\text { others) }\end{array}$ & $\begin{array}{c}\text { AOR for } \\
\text { Hazardous } \\
\text { Task } \\
(95 \% \mathrm{CI})\end{array}$ & $\begin{array}{l}\text { Performed } \\
\text { Prohibited Task } \\
\text { (\% trained with } \\
\text { this method, \% } \\
\text { others) }\end{array}$ & $\begin{array}{c}\text { AOR for } \\
\text { Prohibited } \\
\text { Task } \\
(95 \% \mathrm{CI})\end{array}$ & $\begin{array}{c}\text { Performed } \\
\text { Dangerous Task } \\
\text { (\% trained with } \\
\text { this method, } \% \\
\text { others) }\end{array}$ & $\begin{array}{c}\text { AOR for } \\
\text { Dangerous } \\
\text { Task } \\
\text { (95\% CI) }\end{array}$ & $\begin{array}{c}\text { Median } \\
\text { Dangerous Task } \\
\text { Score } \\
\text { (of those trained } \\
\text { with this method } \\
\text { vs. others) }\end{array}$ \\
\hline $\begin{array}{l}\text { Ways to spot } \\
\text { hazards }\end{array}$ & 110 & $\begin{array}{c}82 \% \text { vs. } 74 \% \\
p=0.13\end{array}$ & $\begin{array}{c}1.84 \\
(0.91-3.73) \\
\end{array}$ & $\begin{array}{c}26 \% \text { vs. } 26 \% \\
p=0.99\end{array}$ & $\begin{array}{c}0.93 \\
(0.49-1.77) \\
\end{array}$ & $\begin{array}{c}84 \% \text { vs. } 75 \% \\
p=0.11 \\
\end{array}$ & $\begin{array}{c}1.67 \\
(0.82-3.38) \\
\end{array}$ & $\begin{array}{l}3 \text { vs. } 2 \\
p=0.60\end{array}$ \\
\hline $\begin{array}{l}\text { Ways to control or } \\
\text { remove hazards }\end{array}$ & 88 & $\begin{array}{c}78 \% \text { vs. } 77 \% \\
p=0.79\end{array}$ & $\begin{array}{c}1.10 \\
(0.54-2.21)\end{array}$ & $\begin{array}{c}25 \% \text { vs. } 26 \% \\
p=0.86\end{array}$ & $\begin{array}{c}1.10 \\
(0.57-2.13) \\
\end{array}$ & $\begin{array}{c}79 \% \text { vs. } 80 \% \\
p=0.85\end{array}$ & $\begin{array}{c}1.01 \\
(0.50-2.05) \\
\end{array}$ & $\begin{array}{c}2.5 \text { vs. } 3 \\
p=0.95\end{array}$ \\
\hline $\begin{array}{l}\text { How to read } \\
\text { warning labels }\end{array}$ & 63 & $\begin{array}{c}83 \% \text { vs. } 76 \% \\
p=0.26 \\
\end{array}$ & $\begin{array}{c}1.72 \\
(0.76-3.92) \\
\end{array}$ & $\begin{array}{c}27 \% \text { vs. } 25 \% \\
\mathrm{p}=0.85\end{array}$ & $\begin{array}{c}1.32 \\
(0.65-2.68) \\
\end{array}$ & $\begin{array}{c}83 \% \text { vs. } 78 \% \\
p=0.42\end{array}$ & $\begin{array}{c}1.65 \\
(0.73-3.73) \\
\end{array}$ & $\begin{array}{c}3 \text { vs. } 2 \\
p=0.02^{a}\end{array}$ \\
\hline $\begin{array}{l}\text { Where to locate/how } \\
\text { to read MSDS }\end{array}$ & 36 & $\begin{array}{c}78 \% \text { vs. } 77 \% \\
p=0.96\end{array}$ & $\begin{array}{c}1.31 \\
(0.51-3.37) \\
\end{array}$ & $\begin{array}{c}19 \% \text { vs. } 27 \% \\
p=0.35\end{array}$ & $\begin{array}{c}0.65 \\
(0.24-1.72) \\
\end{array}$ & $\begin{array}{c}78 \% \text { vs. } 80 \% \\
\text { p }=0.80\end{array}$ & $\begin{array}{c}1.12 \\
(0.44-2.85) \\
\end{array}$ & $\begin{array}{l}2 \text { vs. } 3 \\
p=0.21\end{array}$ \\
\hline What PPE I need & 54 & $\begin{array}{c}76 \% \text { vs. } 78 \% \\
p=0.75\end{array}$ & $\begin{array}{c}1.03 \\
(0.46-2.31) \\
\end{array}$ & $\begin{array}{c}17 \% \text { vs. } 28 \% \\
\mathrm{p}=0.10\end{array}$ & $\begin{array}{c}0.64 \\
(0.27-1.48) \\
\end{array}$ & $\begin{array}{c}76 \% \text { vs. } 80 \% \\
p=0.48\end{array}$ & $\begin{array}{c}0.91 \\
(0.41-2.03) \\
\end{array}$ & $\begin{array}{c}4 \text { vs. } 2 \\
\text { p }<0.01^{a} \\
\end{array}$ \\
\hline $\begin{array}{l}\text { First aid skills/what } \\
\text { to do when someone } \\
\text { is injured }\end{array}$ & 85 & $\begin{array}{c}75 \% \text { vs. } 79 \% \\
p=0.54\end{array}$ & $\begin{array}{c}0.85 \\
(0.42-1.73)\end{array}$ & $\begin{array}{c}25 \% \text { vs. } 26 \% \\
p=0.86\end{array}$ & $\begin{array}{c}1.05 \\
(0.54-2.06)\end{array}$ & $\begin{array}{c}77 \% \text { vs. } 81 \% \\
p=0.46\end{array}$ & $\begin{array}{c}0.88 \\
(0.43-1.81)\end{array}$ & $\begin{array}{c}4 \text { vs. } 2 \\
p=0.01^{a}\end{array}$ \\
\hline Child labor laws & 43 & $\begin{array}{c}86 \% \text { vs. } 76 \% \\
\text { p }=0.14\end{array}$ & $\begin{array}{c}2.41 \\
(0.87-1.73)\end{array}$ & $\begin{array}{c}33 \% \text { vs. } 24 \% \\
\text { p }=0.21\end{array}$ & $\begin{array}{c}1.85 \\
(0.84-4.07)\end{array}$ & $\begin{array}{c}88 \% \text { vs. } 77 \% \\
\text { p }=0.10\end{array}$ & $\begin{array}{c}2.83^{b} \\
(0.96-8.30)\end{array}$ & $\begin{array}{l}3 \text { vs. } 3 \\
p=0.64\end{array}$ \\
\hline $\begin{array}{l}\text { What chemicals are } \\
\text { at my job }\end{array}$ & 52 & $\begin{array}{c}88 \% \text { vs. } 74 \% \\
p=0.03^{2}\end{array}$ & $\begin{array}{c}2.93^{\mathrm{a}} \\
(1.07-8.01)\end{array}$ & $\begin{array}{c}22 \% \text { vs. } 27 \% \\
\text { p }=0.45\end{array}$ & $\begin{array}{c}0.90 \\
(0.41-1.98) \\
\end{array}$ & $\begin{array}{c}88 \% \text { vs. } 77 \% \\
\text { p }=0.06^{b}\end{array}$ & $\begin{array}{c}2.63 \\
(0.97-7.14)\end{array}$ & $\begin{array}{l}3.5 \text { vs. } 2 \\
p=0.03^{a}\end{array}$ \\
\hline $\begin{array}{l}\text { How to operate } \\
\text { equipment }\end{array}$ & 105 & $\begin{array}{c}81 \% \text { vs. } 75 \% \\
p=0.25\end{array}$ & $\begin{array}{c}1.68 \\
(0.82-3.43) \\
\end{array}$ & $\begin{array}{c}35 \% \text { vs. } 18 \% \\
\text { p }<0.01^{\mathrm{a}} \\
\end{array}$ & $\begin{array}{c}2.34^{\mathrm{a}} \\
(1.22-4.50) \\
\end{array}$ & $\begin{array}{c}84 \% \text { vs. } 76 \% \\
p=0.12\end{array}$ & $\begin{array}{c}1.69 \\
(0.82-3.48) \\
\end{array}$ & $\begin{array}{c}3 \text { vs. } 2 \\
p<0.01^{a}\end{array}$ \\
\hline How to do my job & 172 & $\begin{array}{c}79 \% \text { vs. } 73 \% \\
p=0.33\end{array}$ & $\begin{array}{c}1.89 \\
(0.85-4.23)\end{array}$ & $\begin{array}{c}24 \% \text { vs. } 30 \% \\
\text { p }=0.41\end{array}$ & $\begin{array}{c}0.98 \\
(0.47-2.04)\end{array}$ & $\begin{array}{c}79 \% \text { vs. } 80 \% \\
\text { p }=0.94\end{array}$ & $\begin{array}{c}1.50 \\
(0.66-3.39)\end{array}$ & $\begin{array}{l}3 \text { vs. } 2 \\
p=0.48\end{array}$ \\
\hline
\end{tabular}

${ }^{a}$ Corresponds to a statistically significant positive association

${ }^{b}$ Corresponds to a borderline statistically significant positive association 
Table 30 (Continued). Summary of results from analyses answering specific aim 2, question 3

\begin{tabular}{|c|c|c|c|c|c|c|c|c|}
\hline $\begin{array}{l}\text { Safety Training } \\
\text { Lesson }\end{array}$ & $\mathbf{N}$ & $\begin{array}{c}\text { Performed } \\
\text { Hazardous Task } \\
\text { (\% trained with } \\
\text { this method, \% } \\
\text { others) }\end{array}$ & $\begin{array}{c}\text { AOR for } \\
\text { Hazardous } \\
\text { Task } \\
(95 \% \mathrm{CI})\end{array}$ & $\begin{array}{c}\text { Performed } \\
\text { Prohibited Task } \\
\text { (\% trained with } \\
\text { this method, \% } \\
\text { others) }\end{array}$ & $\begin{array}{c}\text { AOR for } \\
\text { Prohibited } \\
\text { Task } \\
(95 \% \text { CI })\end{array}$ & $\begin{array}{c}\text { Performed } \\
\text { Dangerous Task } \\
\text { (\% trained with } \\
\text { this method, \% } \\
\text { others) }\end{array}$ & $\begin{array}{c}\text { AOR for } \\
\text { Dangerous } \\
\text { Task } \\
(95 \% \mathrm{CI})\end{array}$ & $\begin{array}{c}\text { Median } \\
\text { Dangerous Task } \\
\text { Score } \\
\text { (of those trained } \\
\text { with this method } \\
\text { vs. others) }\end{array}$ \\
\hline $\begin{array}{l}\text { Safe lifting } \\
\text { practices }\end{array}$ & 39 & $\begin{array}{c}87 \% \text { vs. } 76 \% \\
\text { p=0.11 }\end{array}$ & $\begin{array}{c}1.89 \\
(0.66-5.40) \\
\end{array}$ & $\begin{array}{c}32 \% \text { vs. } 24 \% \\
\text { p }=0.36\end{array}$ & $\begin{array}{c}1.45 \\
(0.65-3.27) \\
\end{array}$ & $\begin{array}{c}87 \% \text { vs. } 78 \% \\
p=0.18\end{array}$ & $\begin{array}{c}1.73 \\
(0.61-4.94) \\
\end{array}$ & $\begin{array}{c}4 \text { vs. } 2 \\
p=0.04^{a}\end{array}$ \\
\hline $\begin{array}{l}\text { Safe climbing } \\
\text { practices/how to } \\
\text { prevent slips, trips } \\
\text { and falls }\end{array}$ & 79 & $\begin{array}{c}81 \% \text { vs. } 76 \% \\
p=0.36\end{array}$ & $\begin{array}{c}1.48 \\
(0.70-3.11)\end{array}$ & $\begin{array}{c}26 \% \text { vs. } 26 \% \\
p=1.00\end{array}$ & $\begin{array}{c}1.06 \\
(0.53-2.12)\end{array}$ & $\begin{array}{c}82 \% \text { vs. } 78 \% \\
p=0.42\end{array}$ & $\begin{array}{c}1.47 \\
(0.69-3.12)\end{array}$ & $\begin{array}{c}3 \text { vs. } 2 \\
p=0.05^{b}\end{array}$ \\
\hline $\begin{array}{l}\text { What job tasks I } \\
\text { should NOT do }\end{array}$ & 57 & $\begin{array}{c}81 \% \text { vs. } 76 \% \\
p=0.50\end{array}$ & $\begin{array}{c}1.27 \\
(0.55-2.91) \\
\end{array}$ & $\begin{array}{c}22 \% \text { vs. } 27 \% \\
p=0.45\end{array}$ & $\begin{array}{c}0.73 \\
(0.33-1.58) \\
\end{array}$ & $\begin{array}{c}81 \% \text { vs. } 79 \% \\
p=0.77\end{array}$ & $\begin{array}{c}1.10 \\
(0.48-2.52) \\
\end{array}$ & $\begin{array}{c}4 \text { vs. } 2 \\
p<0.01^{a}\end{array}$ \\
\hline $\begin{array}{l}\text { Safe driving } \\
\text { techniques }\end{array}$ & 9 & $\begin{array}{c}100 \% \text { vs. } 77 \% \\
p=0.21 \\
\end{array}$ & - & $\begin{array}{c}78 \% \text { vs. } 24 \% \\
\text { p }<0.01^{\mathrm{a}} \\
\end{array}$ & $\begin{array}{c}10.70^{\mathrm{a}} \\
(2.05-56.0) \\
\end{array}$ & $\begin{array}{c}100 \% \text { vs. } 78 \% \\
\mathrm{p}=0.21\end{array}$ & - & $\begin{array}{c}4 \text { vs. } 2 \\
p=0.06^{b}\end{array}$ \\
\hline Other & 17 & $\begin{array}{c}71 \% \text { vs. } 78 \% \\
p=0.55\end{array}$ & $\begin{array}{c}0.48 \\
(0.13-1.72)\end{array}$ & $\begin{array}{c}19 \% \text { vs. } 26 \% \\
\text { p }=0.77\end{array}$ & $\begin{array}{c}0.54 \\
(0.14-2.10)\end{array}$ & $\begin{array}{c}71 \% \text { vs. } 80 \% \\
\text { p }=0.36\end{array}$ & $\begin{array}{c}0.48 \\
(0.13-1.70) \\
\end{array}$ & $\begin{array}{l}2 \text { vs. } 3 \\
p=0.55\end{array}$ \\
\hline
\end{tabular}

${ }^{a}$ Corresponds to a statistically significant positive association

${ }^{b}$ Corresponds to a borderline statistically significant positive association

Table 31. Linear trend relationships between length of safety training and performing hazardous, prohibited, and dangerous tasks, among all trained teens

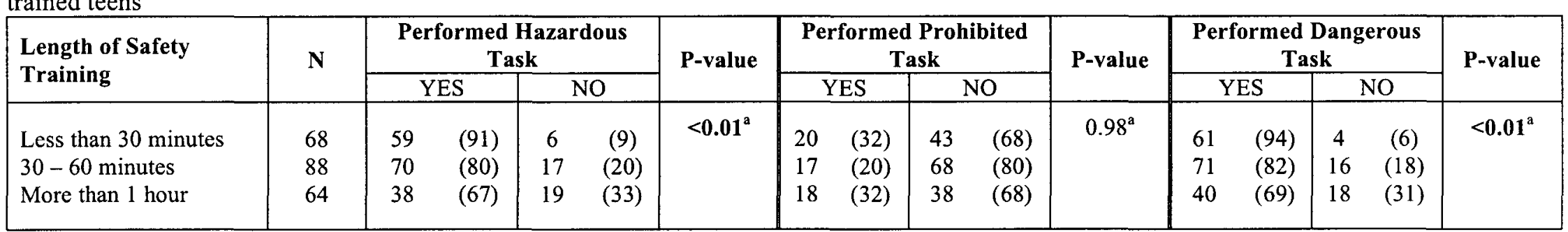

${ }^{a}$ Corresponds to Cochran-Armitage trend test 
Table 32. Safety training length as predictor of hazardous, prohibited, and dangerous task performance in univariable and multivariable logistic regression models among all trained teens

\begin{tabular}{|c|c|c|c|c|c|}
\hline Outcome & $\begin{array}{c}\text { Length of } \\
\text { Safety Training }\end{array}$ & $\begin{array}{l}\text { Crude } \\
\text { Odds } \\
\text { Ratio }\end{array}$ & $\begin{array}{c}95 \% \\
\text { Confidence } \\
\text { Interval }\end{array}$ & $\begin{array}{c}\text { Adjusted } \\
\text { Odds } \\
\text { Ratio* }\end{array}$ & $\begin{array}{c}95 \% \\
\text { Confidence } \\
\text { Interval }\end{array}$ \\
\hline $\begin{array}{c}\text { Performed } \\
\text { hazardous task }\end{array}$ & $\begin{array}{l}\text { Less than } 30 \mathrm{~min} \\
30-60 \mathrm{~min} \\
\text { More than } 1 \mathrm{hr} \text {. }\end{array}$ & $\begin{array}{l}\text { Ref } \\
0.45 \\
0.20\end{array}$ & $\begin{array}{l}0.15-1.31 \\
0.07-0.60\end{array}$ & $\begin{array}{c}\text { Ref } \\
0.38^{\mathrm{a}} \\
0.14^{\mathrm{a}}\end{array}$ & $\begin{array}{l}0.10-1.37 \\
0.40-0.50\end{array}$ \\
\hline $\begin{array}{c}\text { Performed } \\
\text { prohibited task }\end{array}$ & $\begin{array}{l}\text { Less than } 30 \mathrm{~min} \\
30-60 \mathrm{~min} \\
\text { More than } 1 \mathrm{hr} \text {. }\end{array}$ & $\begin{array}{l}\text { Ref } \\
0.53 \\
1.04\end{array}$ & $\begin{array}{l}0.23-1.18 \\
0.46-2.35\end{array}$ & $\begin{array}{c}\operatorname{Ref} \\
0.63^{\mathrm{b}} \\
1.37^{\mathrm{b}}\end{array}$ & $\begin{array}{l}0.24-1.65 \\
0.53-3.54\end{array}$ \\
\hline $\begin{array}{c}\text { Performed } \\
\text { dangerous task }\end{array}$ & $\begin{array}{l}\text { Less than } 30 \mathrm{~min} \\
30-60 \mathrm{~min} \\
\text { More than } 1 \mathrm{hr} \text {. }\end{array}$ & $\begin{array}{l}\text { Ref } \\
0.35 \\
0.17 \\
\end{array}$ & $\begin{array}{l}0.11-1.12 \\
0.05-0.54 \\
\end{array}$ & $\begin{array}{r}\text { Ref } \\
0.35^{\mathrm{c}} \\
0.16^{\mathrm{c}}\end{array}$ & $\begin{array}{l}0.10-1.28 \\
0.04-0.57 \\
\end{array}$ \\
\hline
\end{tabular}

${ }^{*}$ Covariates selected for each model separately using the purposeful selection algorithm.

a Controlling for race, gender, sleep, and communication with parent/guardian

${ }^{b}$ Controlling for race, gender, sleep, communication with parent/guardian, and the feeling that supervisor makes sure they understand workplace safety

${ }^{c}$ Controlling for race, gender, sleep, late hours, and communication with parent/guardian 


\section{DISCUSSION}

\section{Characteristics associated with Performing Dangerous Tasks a. Demographic characteristics}

The results from the analyses have identified relationships between the tasks teens do at work and the demographic variables gender and race. Males were significantly more likely to perform prohibited and dangerous tasks, and more likely, though not significant at the 0.05 alpha level, to perform hazardous tasks $(p=0.08)$. Teenaged males are more likely to be injured at work than females (Breslin \& Pole, 2009; Breslin et al., 2006; Breslin \& Smith, 2006; Zierold \& Anderson, 2006a; Zierold \& Anderson 2006b; Salminen, 2004); their increased likelihood to perform dangerous tasks may contribute to their increased likelihood of injury. It is unclear why males are more likely to do dangerous tasks - they may have a different perspective of what is dangerous, they may be more likely to be asked by their supervisors, or they may have harder times saying no. Breslin et al. (2007) conducted focus groups with Canadian working teenagers, and found that males tended to feel pressure to prove themselves as mature adults at work, which manifested itself as not expressing their safety complaints or concerns. In contrast, the females in the same study reported no issue with expressing their concerns, but rather, that their complaints were dismissed by their supervisors (Breslin et al., 2007b).

Results from the focus groups in this study highlighted gender differences with respect to performing dangerous tasks as well. Teens were asked what they would say to 
their supervisor if they were asked to do something they felt was hazardous or unsafe. Many teens of both genders responded that they would voice their concerns to their supervisor, but females were more likely to express confidence in their refusal of a dangerous task. One female explained, "If I think it's dangerous, even if they would fire me, go right ahead, but I am not doing anything that is dangerous to me." Males, on the contrary, were more likely to say that they would still do the task they felt was dangerous. One male explained that he would do the task because "if they are paying me to do a job and if you tell them no, they could easily go find someone else who would do it." Females may feel more confident saying no to doing dangerous tasks at work, but if their supervisors dismiss their responses or actually threaten to fire them, they could feel forced to do the task. Gender differences like these must be taken into account when safety training is designed and implemented.

Race was significantly associated with the performance of prohibited tasks in this study. This sample of teenagers, with $48 \%$ white, $41 \%$ African-American students, $3 \%$ Hispanic, and $8 \%$ other minorities, is unique among the literature on teen workers. The majority of studies on teenaged workers to date have predominately white samples (Runyan et al., 2009; Rauscher et al., 2008; Zierold \& Anderson, 2006(b); Breslin et al., 2006). The studies with more diverse samples have had included higher proportions of Asian-American teenagers (Rauscher, 2008) and Hispanic-American teenagers (Weller, 2003), but the African-American community has been underrepresented in the literature. Because there are almost equal proportions of white and African-American students, this study may describe the relationship between race and teen safety at work in a new way, compared with other more uniform samples. Among those surveyed, white teenagers 
were more likely to perform prohibited tasks $(37 \%)$ than black teens $(20 \%)$, who were more likely to perform these tasks than Hispanic teens (10\%). Similar racial patterns appeared with respect to those who performed hazardous and dangerous tasks, though these relationships were not statistically significant. One possible reason for racial differences could be that jobs held by teenagers differ by race depending on what is available in certain neighborhoods. Other possibilities that need to be investigated include socioeconomic status (SES) and the reasons teens work - those who are of a lower SES and work to support their family may be more willing to perform prohibited tasks than those of a higher SES working for personal spending money. Sociocultural differences may also impact teens' likelihood to perform dangerous tasks on the job.

\section{b. Behavioral and work-related characteristics}

Other behavioral and work-related characteristics were found to have relationships with the performance of dangerous tasks. The amount of sleep a teen gets at night is known to have an important impact on mental health, cognitive function, academic performance, and risky behaviors like substance abuse (Moore \& Meltzer, 2008; Dahl \& Lewin, 2002). According to the results of this study, it also has a relationship with safety at work. Hours of sleep per night were significantly associated with likelihood of performing hazardous and dangerous tasks. Those who reported 6-7 hours of sleep a night had the highest likelihood of performing hazardous tasks, and those who reported 8 or more hours of sleep had the lowest prevalence of performing dangerous tasks. These relationships could suggest that too little or too much sleep, a potential indicator of depression, may impair teens' judgment at work, leaving them more 
likely to perform dangerous tasks. However, teens working intense, hazardous jobs may also be losing sleep due to additional stress or long work hours.

The age teens first started working has a linear relationship with their likelihood of performing hazardous, prohibited, and dangerous tasks at work. Those who began working at younger ages were more likely to perform hazardous and/or prohibited tasks. For example, $97 \%$ of those who started working when they were 13 years old or younger reported performing dangerous tasks at work, whereas only $73 \%$ of those who started working when they were 17 years old reported performing dangerous tasks. One possible explanation for elevated percentages among those who have been working since they were younger is that teens who have more experience may feel more comfortable doing dangerous tasks. Teenagers' brains are immature and developing, especially their prefrontal cortex - the part of the brain responsible for judgment and evaluating risk (Galvan et al., 2007; Lenroot \& Giedd, 2006; Casey et al., 2005). This could lead teenagers who have work experience to be overly confident and take more risks in the tasks they choose to perform. They may be especially overconfident if they have not experienced an injury in their time working or have been working the same job for extended periods of time. Teens who have more experience may also be asked by their supervisors to perform more dangerous tasks, despite the hazards or laws that regulate them.

Supervision is another key factor that could regulate teens' safety at work. Those who felt that their supervisor did not make sure they understood workplace safety were nearly twice as likely to perform prohibited tasks as those who did feel that their supervisor made sure they understood workplace safety. This suggests that supervisors 
have a strong influence on safety at work, and reflect the environment a teen is working in. Research among adult workers has confirmed the impact of supervisors on a work environment. A study by Smith and DeJoy (2012) showed that support from supervisors in the workplace, including the perception that supervisors care about the wellbeing of those they supervise, was correlated with safety climate, which was a significant protective factor against workplace injury.

Supervisors who make sure their teen employees understand workplace safety likely do not ask their employees to perform tasks prohibited by law or other dangerous tasks. These safety-enforcing supervisors may also be more effective at encouraging teens to follow safety rules at work and may contribute to a safer overall environment at work. Though an overconfident teenager might be tempted to take risks at work, a supervisor who values the teen's safety will prevent the teenager from making dangerous mistakes. This finding highlights the influential role that supervisors can play in the keeping teenagers safe at work.

Teenagers who worked late hours - after 7:00 PM for 14 and 15 year-olds, and after 10:30 PM on school nights and after 11:00 PM on weekend nights for 16 and 17 year-olds - reported performing more dangerous tasks than those who did not work late. This association may exist because of poor judgment due to fatigue after long days, lack of supervision at night, or a difference in the types of jobs that operate at later hours. For example, based on the data from this study, $43 \%$ of those working in restaurants, worked late hours, compared with only $26 \%$ of those working in retail stores. In general, restaurants and fast food establishments have more hazardous tasks than retail stores. Teens working late at night may also be unsupervised and do more dangerous things than 
teens working during the day. Lewko et al. (2010) found that $17 \%$ of teenagers worked, not only without supervision, but completely alone at night, a higher percentage than those who worked alone during the day (14\%). Lack of supervision or any coworkers may lead teenagers to perform more dangerous tasks than when their supervisors or coworkers are around.

This analysis also showed that teens who perform hazardous tasks are three times more likely to perform prohibited tasks than those who do not do hazardous tasks. Furthermore teens who perform prohibited tasks tend to perform a higher number of hazardous tasks as well. These results may indicate that teens who are more willing to take risks in the tasks they perform at work are also more willing to perform tasks that are highly dangerous and prohibited by law. It also suggests that workplaces that do not strictly regulate child labor laws may have a higher number of unregulated hazards that are not being well supervised.

\section{Impact of Safety Training}

This is the first study to present the effect of the various aspects of safety training - methods, lessons taught, and length - on teens' safety at work. The overall variable "safety training," was found to not have any significant effect on whether teens perform hazardous, prohibited, or dangerous tasks at work, or the number of dangerous tasks they perform. However, the results suggest that a lack of safety training may increase rates of performing prohibited tasks, but the elevated AOR was not significant. The elevated AOR indicates that those without safety training are more likely to perform prohibited 
tasks, but the data are limited due to sample size. More research with a larger sample size of teens working prohibited tasks would help clarify these relationships.

Previous research has reported that safety training is not associated with workplace injury among teens (Zierold \& Anderson, 2006(a)). It is possible that safety training is ineffective in preventing injury because it does not prevent teens from performing hazardous tasks, some of which are prohibited by law. Additionally, safety training has many components that may impact teens' decisions to perform certain tasks at work. Some of these safety training components are measured and discussed below, but others that may have been neglected, such as formality and uniformity of training, repetition used in training, and the characteristics of the trainers.

\section{a. Methods of safety training}

Most of the associations from the analyses of the impact of various methods of safety training on teens' likelihood to perform hazardous, prohibited, or dangerous tasks were associated with increased proportions of teens performing dangerous tasks. For example, teens who were trained with safety lectures were five times more likely to perform hazardous tasks, twice as likely to perform prohibited tasks, and six times more likely to perform any dangerous task, compared with their peers who were trained with other methods. The other methods associated with higher proportions of teens who performed dangerous tasks were posters/signs, demonstrations, and practicing accident response. The methods that had lower proportions of teens performing hazardous, prohibited, or dangerous tasks were videos and written quizzes, as well as a borderline association for computer quizzes. 
The fact that most of these methods, especially those that seem to be interactive and hands-on, like demonstrations and practicing accident response, were associated with higher percentages of dangerous task performance is counter-intuitive. However, handson training may have a tendency to be more informal and less structured than videos or quizzes, which may weaken its message or cause teens to interpret the informal lessons as less important. Furthermore, videos and quizzes are often training methods for large, national businesses like popular fast food restaurants that have the infrastructure to create and distribute uniform safety programs. Though these methods are less hands-on, the businesses that are more likely to use them may also be more likely to regulate safety more uniformly due to structural differences compared to smaller or local businesses. Videos and quizzes are also methods that most teens receive in school, which may legitimize them in teens' minds, and send a stronger message about safety than other methods.

In the focus groups in this study, teens voiced what they felt would be effective training methods. Their opinions appeared to contradict the results of the analyses of the survey data. Teens frequently described videos, the most commonly received method of training, as "boring" and less effective than if "someone is actually talking to you". The type of training they described as effective and desirable was hands-on and interactive. Teens expressed the desire for training to include "actually being out doing all of this stuff, having them [supervisors] walk you through it" because "it just works a lot better" and "once you actually do it for yourself, then it kind of gives you muscle memory." Another teenager who had interactive games with rewards as a part of her training 
thought they were effective because "everybody wants a prize, so that was a good way for us to learn it, I feel, "cause everybody wanted to participate."

These results suggest that safety training programs should be structured, and videos and quizzes may be good methods to provide that structure. However, it is equally important to reinforce lessons with hands-on training, as teenagers in the focus groups explained. A combination of methods would likely result in the safest environment for working teens.

\section{b. Lessons of safety training}

The associations found with the lessons taught in safety training were all associated with an increased likelihood of performing hazardous, prohibited, or dangerous tasks, or an increased likelihood of performing more dangerous tasks. Lessons that were associated with an increased likelihood of performing hazardous, prohibited, or dangerous tasks were: "How to read warning labels", "What PPE I need", "First aid skills/what to do when someone is injured", "What chemicals are at my job", "How to operate equipment", "Safe lifting practices", "Safe climbing practices/how to prevent slips, trips, and falls", "What job tasks I should NOT do", and "Safe driving techniques". These associations suggest that these safety training lessons are not preventing teenagers from performing hazardous, prohibited, or dangerous tasks. Teens oftentimes take risks at work in performing more dangerous tasks than they should, but some hazardous tasks may be required for their jobs. However, future analysis is needed to determine whether the safety training lessons teens receive actually prevent injury while performing these hazardous tasks. 
However, the lessons associated with prohibited tasks - how to operate equipment and safe driving techniques - may indicate an unsafe work environment, as teenagers should never be performing tasks that are prohibited by law. The first of these lessons, how to operate equipment, is not a true lesson of safety training, but rather job training, indicating a lack of understanding of what safety training is among the teenagers who chose this option. This could be a sign that a teenager's workplace lacks safety training altogether or does not make clear to their teenaged employees what safety is, which may lead teens to perform more hazardous and prohibited tasks.

Only nine teenagers responded that they had received the second lesson associated with prohibited tasks, safe driving techniques. Due to the small sample size of this analysis, these results should be interpreted with caution. This association could indicate that most of the teenagers who were trained to drive were too young to drive by child labor law standards. However, there are special exceptions to the driving age in the child labor laws, so some of these cases could actually be legal.

\section{c. Length of safety training}

When length of safety training was analyzed, linear relationships emerged with the performance of hazardous and dangerous tasks. Those trained longer were less likely to perform these tasks. This finding is novel and presents an opportunity for intervention. Longer safety training may send a stronger message to teens about the importance of safety, it may allow for trainers to include more repetition and detail into safe work practices, and it may give teens more time to learn the material or ask questions. However, the association could reflect the opposite - that safer workplaces simply have 
longer trainings. Further analysis on safety training length, focusing on job type, injury rates, and indicators of safety climate could help determine the exact effect of this finding.

A relationship with length of training did not exist with the performance of prohibited tasks. This may be due to the work environments of those performing prohibited tasks - if teens are working in unsafe environments where they are being asked to do prohibited tasks, longer safety training may not make any difference.

\section{Limitations}

Limitations of this study are that the sample is comprised of teenagers from Louisville, Kentucky, which may not be representative of teenagers throughout the country. Though African-Americans are well represented in the sample, other minorities are underrepresented. However, the jobs held by teens in this survey are similar to those held by teens in past surveys - namely, service and retail as the primary industries (Dal Santo \& Bowling, 2009; Runyan et al., 2009; Zierold et al., 2005; Weller et al., 2003; Herman, 2000).

Another limitation is that recall bias could be present because participants selfreported on tasks at work, relationships with supervisors, and safety training received. However, to minimize this bias, we asked only individuals who currently held a job to answer the questions corresponding to their job. Individuals who had worked in the past were not asked about their previous work experiences. 
Finally, in some analyses where the data were stratified, the sample size is small. This results in wide confidence intervals in some analyses, which means that these analyses were less sensitive in detecting weaker effects of certain risk factors.

\section{Summary and Implications}

The performance of hazardous and prohibited tasks put teenagers in danger at work, especially given teens' immature brains and the social dynamics of the workplace. Teenagers are often treated like adults in the workplace, as is evident from the dangerous tasks they are assigned, some of which are prohibited by law. Teens who have been working for years already may be especially pressured to taking on more adult-like duties than they should be, and they may accept this responsibility willingly, as a way to prove their value in the workforce. They also may accept this responsibility because they are less likely to identify risks and control their impulses, as cognitive functions like constraint and mistake recognition are still developing throughout adolescence (Blonigen, 2008; Monastersky, 2007).

The important findings that this thesis introduces are new insights into the impact of race on safety in the workplace, and that longer length of safety training may reduce the likelihood that teens perform hazardous and dangerous tasks on the job. Certain training methods may be associated with increased or decreased hazardous and dangerous task performance, but these associations could also be attributable to other factors not evaluated, such as the size and organization of the company, which might have more supervision or oversight, or how structured and developed the safety training program is. 
Though analysis of the methods and lessons taught in safety training do not give clear implications of what should be taught in safety training to prevent teens' from performing dangerous tasks, it is clear that a combination of methods and lessons, longer length of training, supervision, and work characteristics are factors in preventing teens from doing dangerous tasks.

To prevent teens from performing prohibited tasks, a better examination of the workplaces where these tasks are performed is needed. Safety training and more informed supervisors and workplace managers may be needed. Enforcement of child labor laws also are needed, especially in smaller workplaces or workplaces where teens are likely to do prohibited tasks. Additionally, awareness to child labor laws, including tasks that are prohibited for certain age groups, should be raised among teenagers through public awareness campaigns or education programs built into middle and high school curricula. 


\section{REFERENCES}

Blonigen DM, Carlson MD, Hicks BM, et al. Stability and change in personality traits from late adolescence to early adulthood: A longitudinal twin study. J Pers. 2008; $76(2): 229-266$.

Braun V, Clarke V. Using thematic analysis in psychology. Qualitative Research in Psychology. 2006;3:77-101.

Breslin C, Koehoorn M, Smith P, Manno M. Age related differences in work injuries and permanent impairment: a comparison of workers' compensation claims among adolescents, young adults, and adults. Occup Environ Med. 2003;60(9):e10 (http://occenvmed.com/cgi/content/full/60/9/e10).

Breslin FC and Smith P. Age-related differences in work injuries: a multivariate, population-based study. Am J Ind Med. 2005;48:50-56.

Breslin FC and Smith P. Trial by fire: a multivariate examination of the relation between job teńure and work injuries. Occup Environ Med. 2006;63:27-32.

(a) Breslin FC, Day D, Tompa E, et al. Non-agricultural work injuries among youth: A systematic review. Am J Prev Med. 2007;32(2):151-162.

(b) Breslin FC, Pole JD, Tompa E, et al. Antecedents of work disability absence among young people: A prospective study. Ann Epidemiol. 2007;17(10):814-820.

Breslin FC, Pole JD. Work injury risk among young people with learning disabilities and Attention-Deficit/Hyperactivity Disorder in Canada. Am J Pub Health. 2009;99(8):1423-1430.

(c) Breslin FC, Polzer J, MacEachen E, et al. Workplace injury or "part of the job"?: Towards a gendered understanding of injuries and complaints among young workers. Soc Sci Med. 2007; 64:782-793.

Breslin FC, Smith P, Mustard C, Zhao R. Young people and work injuries: an examination of jurisdictional variation within Canada. Inj Prev. 2006;12:105-110.

Burke MJ, Sarpy SA, Smith-Crowe K, et al. Relative effectiveness of worker safety and health training methods. Am J Pub Health. 2006;96(2):315-324. 
Bursac Z, Gauss CH, Williams DK, and Hosmer DW. Purposeful selection of variables in logistic regression. Source Code Biol Med. 2008;16(3):17.

Casey BJ, Galvan A, and Hare TA. Changes in cerebral functional organization during cognitive development. Curr Opin Neurobiol. 2005; 15(2):239-244.

Centers for Disease Control and Prevention. Occupational Injuries and Deaths Among Younger Workers - United States, 1998-2007. Morbidity and Mortality Weekly Report. 2010;59(15):449-455.

Clarke CM. U.S. Bureau of Labor Statistics. Workplace injuries and illnesses in grocery stores. Compensation and Working Conditions Online. 2003.

Dahl RE and Lewin DS. Pathways to adolescent health sleep regulation and behavior. $J$ Adolesc Health. 2002;31(6 Suppl):175-184.

Dal Santo JA and Bowling JM. Characteristics of teens with and without work permits. Am J Indust Med. 2009;52:841-849.

Dal Santo JA, Bowling JM, Harris TA. Effects of work permits on illegal employment among young workers: Findings of a school-based survey on child labor violations. Am J Pub Health. 2010;100(4):635-637.

Dunbar RLM. Manager's influence on subordinates' thinking about safety. Academy of Management Journal. 1975;18(2):364-369.

Evensen CT, Schulman MD, Runyan CW, et al. The downside of adolescent employment: hazards and injuries among working teens in North Carolina. $J$ Adol. 2000;23:545-560.

Frone MR. Predictors of work injuries among employed adolescents. J Appl Psychol. 1998;83(4):565-576.

Galvan A, Hare T, Henning V, et al. Risk-taking and the adolescent brain: who is at risk? Dev Sci. 2007;10(2):F8-F14.

Grossman J. "Fair Labor Standards Act of 1938: Maximum struggle for a minimum wage." Monthly Labor Review. June 1978.

Herman AM. Report on the Youth Labor Force. Washington, D.C.: Office of Publications and Special Studies, U.S. Department of Labor, Bureau of Labor Statistics; 2000.

Lenroot RK and Giedd JN. Brain development in children and adolescents: Insights from anatomical magnetic resonance imaging. Neurosci Biobehav Rev.

2006;30(6):718-729. 
Lewko JH, Runyan CW, Tremblay CLS, Staley JA, and Volpe R. Workplace experiences of young workers in Ontario. Can J Public Health. 2010;101(5):380-384.

Monastersky R. Who's minding the teenage brain? Chronicle of Higher Education. Jan. $12,2007$.

Moore $\mathrm{M}$ and Meltzer LJ. The sleepy adolescent: causes and consequences of sleepiness in teens. Paediatr Respir Rev. 2008;9(2):114-120.

National Institute for Occupational Safety and Health. NIOSH Alert: Preventing Deaths, Injuries, and Illnesses of Young Workers. Cincinnati, OH: Department of Health and Human Services, Centers for Disease Control and Prevention; 2003.

Patton, MQ. Qualitative evaluation and research methods. 1990;2.

Rauscher KJ and Myers DJ. Socioeconomic disparities in the prevalence of work-related injuries among adolescents in the United States. $J$ Adol Health. 2008;42:50-57.

Rauscher KJ, Runyan CW, and Schulman M. Awareness and knowledge of the U.S. child labor laws among a national sample of working adolescents and their parents. $J$ Adol Health. 2010;47:414-417.

Rauscher KJ, Runyan CW, Schulman MD, and Bowling M. U.S. child labor violations in the retail and service industries: findings from a national survey of working adolescents. Am J Pub Health. 2008;98(9):1693-1699.

Runyan CW, Schulman M, Dal Santo J, Bowling JM, Agans R, and Ta M. Work-related hazards and workplace safety of U.S. adolescents employed in the retail and service sectors. Pediatrics. 2007;119:526-534.

Runyan CW, Schulman M, Dal Santo J, et al. Attitudes and beliefs about adolescent work and workplace safety among parents of working adolescents. $J$ Adol Health. 2009; 44:349-355.

Runyan CW, Vladutiu CJ, Rauscher KJ, and Schulman M. Teen workers' exposures to occupational hazards and use of personal protective equipment. Am J Indust Med. 2008;51:735-740.

Runyan CW, Zakocs RC. Epidemiology and prevention of injuries among adolescent workers in the United States. Annu Rev Public Health. 2000. 21:247-269.

Salminen S. Have young workers more injuries than older ones? An international literature review. $J$ Safety Res. 2004;35(5):513-521.

Smith TD and DeJoy DM. Occupational injury in America: An analysis of risk factors using data from the General Social Survey (GSS). J Safety Res. 2012;43(1):67-74. 
U.S. Department of Labor, Wage and Hour Division. The Fair Labor Standards Act Of 1938, As Amended. WH Publication 1318. Revised May 2011.

Vladutiu CJ, Rauscher KJ, Runyan CW, et al. Hazardous task recognition among U.S. adolescents working in the retail or service industry. Am J Indust Med. 2010;53:686-692.

Wegman DH and Davis LK. Protecting youth at work. Am J Indust Med. 1999;36:579583.

Weller NF, Cooper SP, Basen-Engquist K, Kelder SH, Tortolero SR. The prevalence and patterns of occupational injury among South Texas high school students. Texas Med. 2003;99(8):52-57.

Windau $\mathbf{J}$ and Meyer S. Occupational injuries among young workers. Monthly Labor Review. 2005;128(10):11-23.

(a) Zierold KM and Anderson HA. Severe injury and the need for safety training among working teens. Am J Health Behav. 2006;30(5):525-532.

(b) Zierold KM and Anderson HA. Racial and ethnic disparities in work-related injuries among teenagers. J Adol Health. 2006;39:422-426.

Zierold KM, Appana S and Anderson HA. School-sponsored work programs: a first look at differences in work and injury outcomes of teens enrolled in school-to-work programs compared to other-working teens. Occup Environ Med. 201 1;68:818825.

Zierold KM, Garman S, and Anderson HA. A comparison of school performance and behaviors among working and nonworking high school students. Fam Community Health. 2005;28(3):214-224.

Zierold KM, Welsh EC, and McGeeney TJ. Attitudes of teenagers towards workplace safety training. J Community Health. 2012 May 22 [Epub ahead of print]. 


\section{APPENDIX}

Table 14. Relationships between safety training methods and hazardous task performance among all trained teens (Full table)

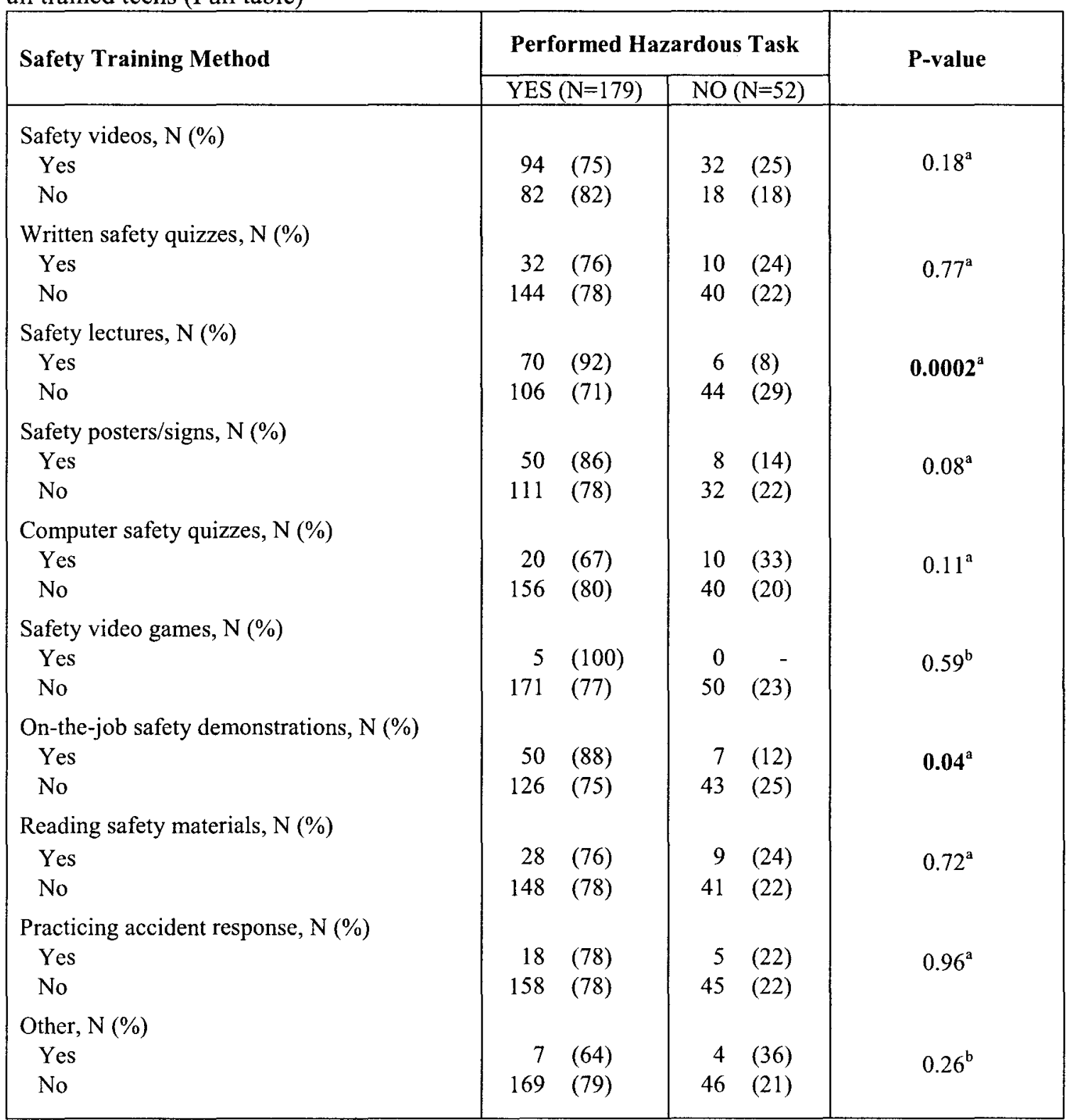

${ }^{a}$ Corresponds to chi-square test

${ }^{\mathrm{b}}$ Corresponds to Fisher's exact test 
Table 15. Logistic regression predicting hazardous task performance by the receipt of safety training methods among all trained teens (Full table)

\begin{tabular}{|c|c|c|c|c|}
\hline Safety Training Method & $\begin{array}{l}\text { Crude } \\
\text { Odds } \\
\text { Ratio }\end{array}$ & $\begin{array}{c}95 \% \\
\text { Confidence } \\
\text { Interval }\end{array}$ & $\begin{array}{c}\text { Adjusted Odds } \\
\text { Ratio* }^{*}\end{array}$ & $\begin{array}{c}\mathbf{9 5 \%} \\
\text { Confidence } \\
\text { Interval } \\
\end{array}$ \\
\hline $\begin{array}{l}\text { Safety videos } \\
\text { Yes } \\
\text { No }\end{array}$ & $\begin{array}{l}0.69 \\
\text { Ref }\end{array}$ & $0.39-1.30$ & $\begin{array}{l}0.60 \\
\text { Ref }\end{array}$ & $0.29-1.24$ \\
\hline $\begin{array}{l}\text { Written safety quizzes } \\
\text { Yes } \\
\text { No }\end{array}$ & $\begin{array}{l}0.91 \\
\text { Ref }\end{array}$ & $0.42-2.01$ & $\begin{array}{l}1.38 \\
\text { Ref }\end{array}$ & $0.54-3.51$ \\
\hline $\begin{array}{l}\text { Safety lectures } \\
\text { Yes } \\
\text { No }\end{array}$ & $\begin{array}{r}4.92 \\
\text { Ref }\end{array}$ & $2.00-12.14$ & $\begin{array}{l}4.96 \\
\text { Ref }\end{array}$ & $1.91-12.90$ \\
\hline $\begin{array}{l}\text { Safety posters/signs } \\
\text { Yes } \\
\text { No }\end{array}$ & $\begin{array}{l}2.13 \\
\text { Ref }\end{array}$ & $0.94-4.85$ & $\begin{array}{l}2.66 \\
\text { Ref }\end{array}$ & $1.04-6.75$ \\
\hline $\begin{array}{l}\text { Computer safety quizzes } \\
\text { Yes } \\
\text { No }\end{array}$ & $\begin{array}{l}0.53 \\
\text { Ref }\end{array}$ & $0.23-1.21$ & $\begin{array}{l}0.58 \\
\text { Ref }\end{array}$ & $0.22-1.56$ \\
\hline $\begin{array}{l}\text { Safety video games } \\
\text { Yes } \\
\text { No }\end{array}$ & $\begin{array}{l}\text { Not } \\
\text { enough } \\
\text { data }\end{array}$ & & & \\
\hline $\begin{array}{l}\text { On-the-job safety demonstrations } \\
\text { Yes } \\
\text { No }\end{array}$ & $\begin{array}{l}2.49 \\
\text { Ref }\end{array}$ & $1.05-5.89$ & $\begin{array}{l}2.60 \\
\text { Ref }\end{array}$ & $1.04-6.50$ \\
\hline $\begin{array}{l}\text { Reading safety materials } \\
\text { Yes } \\
\text { No }\end{array}$ & $\begin{array}{l}0.89 \\
\text { Ref }\end{array}$ & $0.39-2.02$ & $\begin{array}{l}0.90 \\
\text { Ref }\end{array}$ & $0.35-2.27$ \\
\hline $\begin{array}{l}\text { Practicing accident response } \\
\text { Yes } \\
\text { No }\end{array}$ & $\begin{array}{l}1.05 \\
\text { Ref }\end{array}$ & $0.37-2.98$ & $\begin{array}{l}0.93 \\
\text { Ref }\end{array}$ & $0.29-2.97$ \\
\hline $\begin{array}{l}\text { Other } \\
\text { Yes } \\
\text { No }\end{array}$ & $\begin{array}{l}0.49 \\
\text { Ref }\end{array}$ & $0.14-1.74$ & $\begin{array}{l}0.35 \\
\text { Ref }\end{array}$ & $0.07-1.74$ \\
\hline
\end{tabular}

${ }^{*}$ Controlled for race, gender, sleep, and communication with parent/guardian 
Table 16. Relationships between safety training methods and prohibited task performance among all trained teens (Full table)

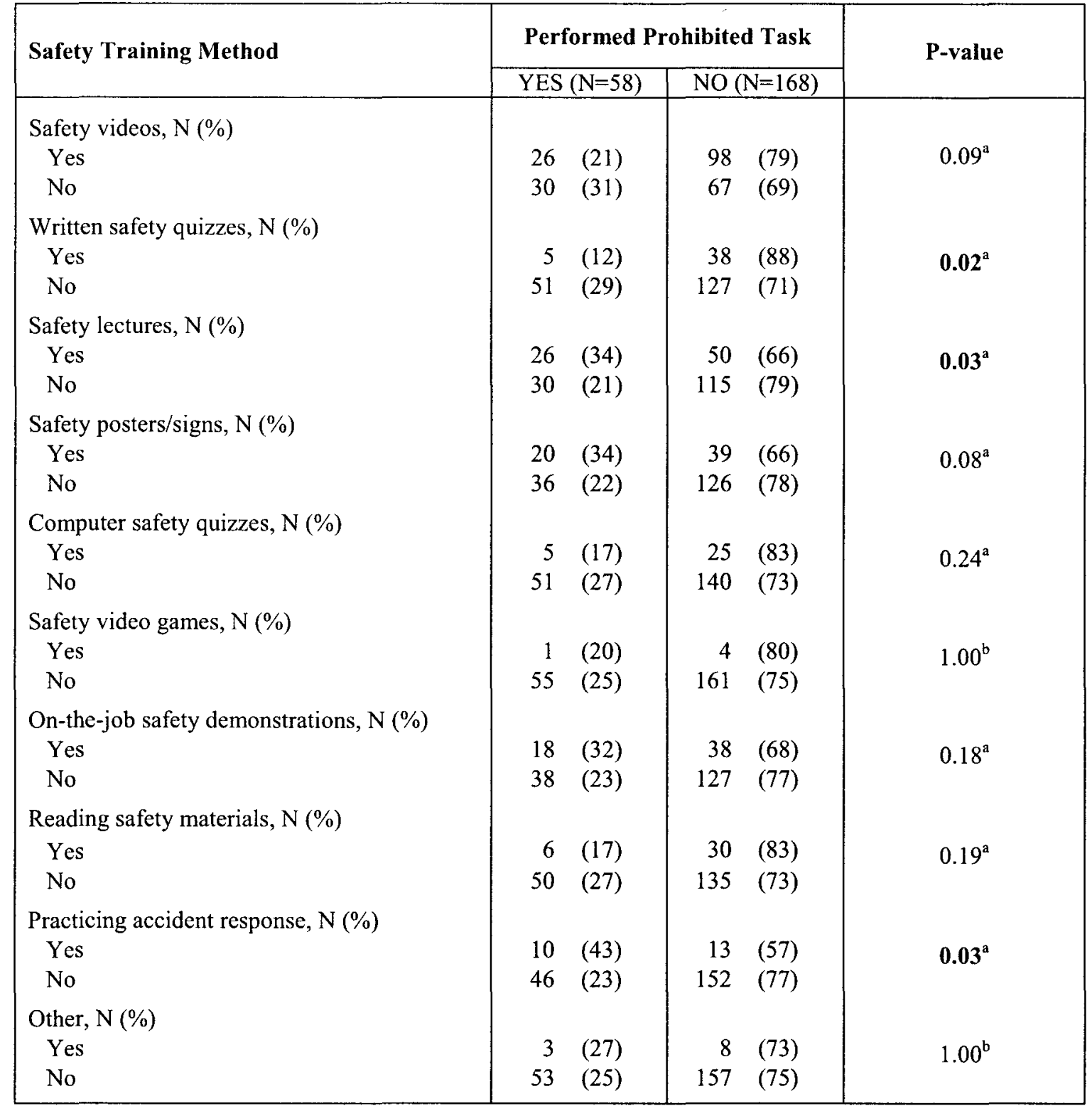

${ }^{a}$ Corresponds to chi-square test

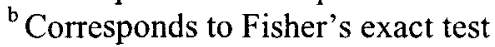


Table 17. Logistic regression predicting prohibited task performance by the receipt of safety training methods among all trained teens (Full table)

\begin{tabular}{|c|c|c|c|c|}
\hline Safety Training Method & $\begin{array}{l}\text { Crude } \\
\text { Odds } \\
\text { Ratio } \\
\end{array}$ & $\begin{array}{c}95 \% \\
\text { Confidence } \\
\text { Interval } \\
\end{array}$ & $\begin{array}{c}\text { Adjusted } \\
\text { Odds Ratio* }\end{array}$ & $\begin{array}{c}95 \% \\
\text { Confidence } \\
\text { Interval } \\
\end{array}$ \\
\hline $\begin{array}{l}\text { Safety videos } \\
\text { Yes } \\
\text { No }\end{array}$ & $\begin{array}{l}0.58 \\
\text { Ref }\end{array}$ & $0.32-1.06$ & $\begin{array}{l}0.64 \\
\text { Ref }\end{array}$ & $0.32-1.22$ \\
\hline $\begin{array}{l}\text { Written safety quizzes } \\
\text { Yes } \\
\text { No }\end{array}$ & $\begin{array}{l}\mathbf{0 . 3 2} \\
\text { Ref }\end{array}$ & $0.12-0.87$ & $\begin{array}{l}0.27 \\
\text { Ref }\end{array}$ & $0.09-0.81$ \\
\hline $\begin{array}{l}\text { Safety lectures } \\
\text { Yes } \\
\text { No }\end{array}$ & $\begin{array}{l}1.92 \\
\text { Ref }\end{array}$ & $1.04-3.54$ & $\begin{array}{r}2.03 \\
\text { Ref }\end{array}$ & $1.06-3.87$ \\
\hline $\begin{array}{l}\text { Safety posters/signs } \\
\text { Yes } \\
\text { No }\end{array}$ & $\begin{array}{l}1.74 \\
\operatorname{Ref}\end{array}$ & $0.91-3.33$ & $\begin{array}{l}2.42 \\
\text { Ref }\end{array}$ & $1.16-5.04$ \\
\hline $\begin{array}{l}\text { Computer safety quizzes } \\
\text { Yes } \\
\text { No }\end{array}$ & $\begin{array}{l}0.54 \\
\text { Ref }\end{array}$ & $0.20-1.48$ & $\begin{array}{l}0.87 \\
\text { Ref }\end{array}$ & $0.29-2.60$ \\
\hline $\begin{array}{l}\text { Safety video games } \\
\text { Yes } \\
\text { No }\end{array}$ & $\begin{array}{l}0.72 \\
\text { Ref }\end{array}$ & $0.08-6.57$ & $\begin{array}{l}1.49 \\
\text { Ref }\end{array}$ & $0.15-14.83$ \\
\hline $\begin{array}{l}\text { On-the-job safety demonstrations } \\
\text { Yes } \\
\text { No }\end{array}$ & $\begin{array}{l}1.54 \\
\operatorname{Ref}\end{array}$ & $0.79-3.00$ & $\begin{array}{l}1.77 \\
\text { Ref }\end{array}$ & $0.87-3.60$ \\
\hline $\begin{array}{l}\text { Reading safety materials } \\
\text { Yes } \\
\text { No }\end{array}$ & $\begin{array}{l}0.53 \\
\text { Ref }\end{array}$ & $0.21-1.35$ & $\begin{array}{l}0.63 \\
\text { Ref }\end{array}$ & $0.24-1.71$ \\
\hline $\begin{array}{l}\text { Practicing accident response } \\
\text { Yes } \\
\text { No }\end{array}$ & $\begin{array}{l}2.48 \\
\operatorname{Ref}\end{array}$ & $1.02-6.02$ & $\begin{array}{l}3.21 \\
\text { Ref }\end{array}$ & $1.21-8.45$ \\
\hline $\begin{array}{l}\text { Other } \\
\text { Yes } \\
\text { No }\end{array}$ & $\begin{array}{l}1.09 \\
\operatorname{Ref}\end{array}$ & $0.28-4.26$ & $\begin{array}{l}1.12 \\
\text { Ref }\end{array}$ & $0.25-4.97$ \\
\hline
\end{tabular}

${ }^{*}$ Controlling for race, gender, feeling that their supervisor makes sure they understand workplace safety, and communication with parent/guardian 
Table 18. Relationships between safety training methods and dangerous task performance among all trained teens (Full table)

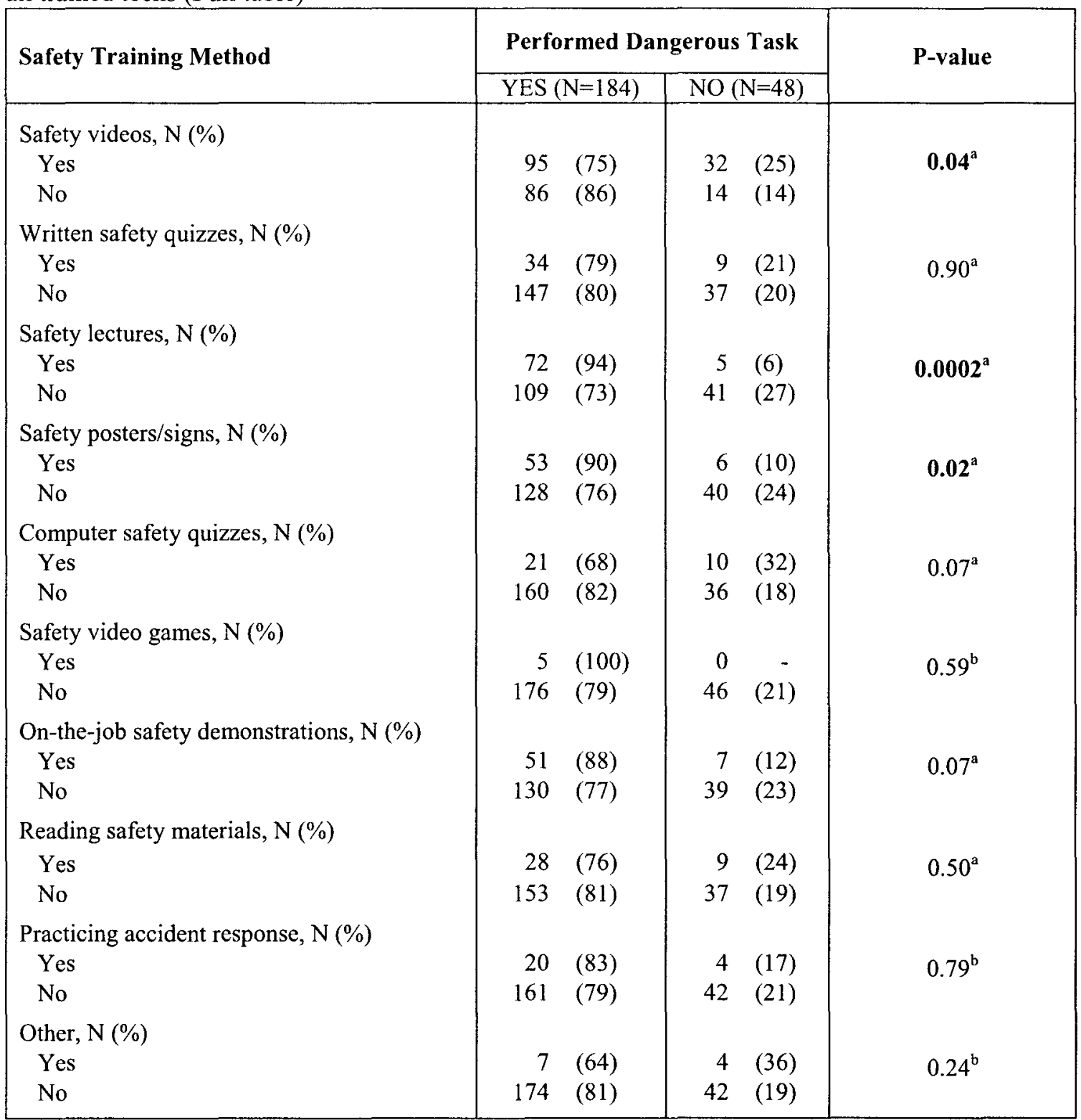

${ }^{a}$ Corresponds to chi-square test

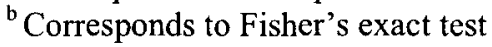


Table 19. Logistic regression predicting dangerous task performance by the receipt of safety training methods among all trained teens (Full table)

\begin{tabular}{|c|c|c|c|c|}
\hline Safety Training Method & $\begin{array}{l}\text { Crude } \\
\text { Odds } \\
\text { Ratio } \\
\end{array}$ & $\begin{array}{c}95 \% \\
\text { Confidence } \\
\text { Interval } \\
\end{array}$ & $\begin{array}{c}\text { Adjusted } \\
\text { Odds Ratio* }\end{array}$ & $\begin{array}{c}95 \% \\
\text { Confidence } \\
\text { Interval } \\
\end{array}$ \\
\hline $\begin{array}{l}\text { Safety videos } \\
\text { Yes } \\
\text { No }\end{array}$ & $\begin{array}{l}0.53 \\
\text { Ref }\end{array}$ & $0.27-1.04$ & $\begin{array}{l}0.53 \\
\operatorname{Ref}\end{array}$ & $0.25-1.10$ \\
\hline $\begin{array}{l}\text { Written safety quizzes } \\
\text { Yes } \\
\text { No }\end{array}$ & $\begin{array}{l}0.98 \\
\text { Ref }\end{array}$ & $0.44-2.22$ & $\begin{array}{l}1.33 \\
\text { Ref }\end{array}$ & $0.53-3.34$ \\
\hline $\begin{array}{l}\text { Safety lectures } \\
\text { Yes } \\
\text { No }\end{array}$ & $\begin{array}{l}5.53 \\
\text { Ref }\end{array}$ & $2.09-14.62$ & $\begin{array}{l}6.04 \\
\operatorname{Ref}\end{array}$ & $2.18-16.72$ \\
\hline $\begin{array}{l}\text { Safety posters/signs } \\
\text { Yes } \\
\text { No }\end{array}$ & $\begin{array}{l}2.83 \\
\text { Ref }\end{array}$ & $1.14-7.06$ & $\begin{array}{l}3.13 \\
\operatorname{Ref}\end{array}$ & $1.17-8.36$ \\
\hline $\begin{array}{l}\text { Computer safety quizzes } \\
\text { Yes } \\
\text { No }\end{array}$ & $\begin{array}{l}0.49 \\
\text { Ref }\end{array}$ & $0.21-1.13$ & $\begin{array}{l}0.58 \\
\operatorname{Ref}\end{array}$ & $0.22-1.55$ \\
\hline $\begin{array}{l}\text { Safety video games } \\
\text { Yes } \\
\text { No }\end{array}$ & $\begin{array}{l}\text { Not } \\
\text { enough } \\
\text { data }\end{array}$ & & & \\
\hline $\begin{array}{l}\text { On-the-job safety demonstrations } \\
\text { Yes } \\
\text { No }\end{array}$ & $\begin{array}{l}2.25 \\
\text { Ref }\end{array}$ & $0.95-5.33$ & $\begin{array}{l}2.49 \\
\text { Ref }\end{array}$ & $1.00-6.19$ \\
\hline $\begin{array}{l}\text { Reading safety materials } \\
\text { Yes } \\
\text { No }\end{array}$ & $\begin{array}{l}0.78 \\
\text { Ref }\end{array}$ & $0.34-1.78$ & $\begin{array}{l}0.79 \\
\text { Ref }\end{array}$ & $0.31-2.00$ \\
\hline $\begin{array}{l}\text { Practicing accident response } \\
\text { Yes } \\
\text { No }\end{array}$ & $\begin{array}{l}1.34 \\
\operatorname{Ref}\end{array}$ & $0.44-4.13$ & $\begin{array}{l}1.38 \\
\text { Ref }\end{array}$ & $0.40-4.69$ \\
\hline $\begin{array}{l}\text { Other } \\
\text { Yes } \\
\text { No }\end{array}$ & $\begin{array}{l}0.44 \\
\text { Ref }\end{array}$ & $0.12-1.55$ & $\begin{array}{l}0.35 \\
\text { Ref }\end{array}$ & $0.07-1.71$ \\
\hline
\end{tabular}

*Controlled for race, gender, sleep, and communication with parent/guardian 
Table 20. Differences in dangerous task scores between recipients of specific methods of safety training, among all trained teens who performed at least one dangerous task (Full table)

\begin{tabular}{|c|c|c|c|c|}
\hline Safety Training Method & $\mathbf{N}$ & $\begin{array}{c}\text { Median } \\
\text { Dangerous Task } \\
\text { Score (Range) } \\
\end{array}$ & Test statistic & P-value \\
\hline $\begin{array}{l}\text { Safety videos } \\
\text { Yes } \\
\text { No }\end{array}$ & $\begin{array}{l}95 \\
86\end{array}$ & $\begin{array}{ll}2 & (1-17) \\
3 & (1-13)\end{array}$ & $\mathbf{U}=4059^{\mathrm{a}}$ & $0.94^{\mathrm{a}}$ \\
\hline $\begin{array}{l}\text { Written safety quizzes } \\
\text { Yes } \\
\text { No }\end{array}$ & $\begin{array}{c}34 \\
147\end{array}$ & $\begin{array}{ll}2 & (1-10) \\
3 & (1-17)\end{array}$ & $\mathbf{U}=2313.5^{\mathrm{a}}$ & $0.49^{\mathrm{a}}$ \\
\hline $\begin{array}{l}\text { Safety lectures } \\
\text { Yes } \\
\text { No }\end{array}$ & $\begin{array}{c}72 \\
109\end{array}$ & $\begin{array}{ll}3 & (1-13) \\
2 & (1-17)\end{array}$ & $\mathrm{U}=3418.5^{\mathrm{a}}$ & $0.14^{\mathrm{a}}$ \\
\hline $\begin{array}{l}\text { Safety posters/signs } \\
\text { Yes } \\
\text { No }\end{array}$ & $\begin{array}{c}53 \\
128\end{array}$ & $\begin{array}{ll}3 & (1-15) \\
2 & (1-17)\end{array}$ & $\mathbf{U}=2977.5^{\mathrm{a}}$ & $0.19^{\mathrm{a}}$ \\
\hline $\begin{array}{l}\text { Computer safety quizzes } \\
\text { Yes } \\
\text { No }\end{array}$ & $\begin{array}{c}21 \\
160\end{array}$ & $\begin{aligned} 4 & (1-15) \\
2.5 & (1-17)\end{aligned}$ & $\mathbf{U}=1501.5^{\mathrm{a}}$ & $0.42^{\mathrm{a}}$ \\
\hline $\begin{array}{l}\text { Safety video games } \\
\text { Yes } \\
\text { No }\end{array}$ & $\begin{array}{c}5 \\
152\end{array}$ & $\begin{array}{ll}4 & (2-10) \\
3 & (1-17)\end{array}$ & $\mathrm{U}=303^{\mathrm{b}}$ & $0.23^{\mathrm{b}}$ \\
\hline $\begin{array}{l}\text { On-the-job safety demonstrations } \\
\text { Yes } \\
\text { No }\end{array}$ & $\begin{array}{c}51 \\
130\end{array}$ & $\begin{array}{ll}4 & (1-13) \\
2 & (1-17)\end{array}$ & $\mathbf{U}=2396.5^{\mathrm{a}}$ & $\mathbf{0 . 0 0 3}^{\mathrm{a}}$ \\
\hline $\begin{array}{l}\text { Reading safety materials } \\
\text { Yes } \\
\text { No }\end{array}$ & $\begin{array}{c}28 \\
153\end{array}$ & $\begin{array}{rr}3.5 & (1-13) \\
2 & (1-17)\end{array}$ & $\mathbf{U}=1743.5^{\mathrm{a}}$ & $0.11^{\mathrm{a}}$ \\
\hline $\begin{array}{l}\text { Practicing accident response } \\
\text { Yes } \\
\text { No }\end{array}$ & $\begin{array}{c}20 \\
161\end{array}$ & $\begin{array}{ll}2 & (1-10) \\
3 & (1-17)\end{array}$ & $\mathbf{U}=1476^{\mathrm{a}}$ & $0.54^{\mathrm{a}}$ \\
\hline $\begin{array}{l}\text { Other } \\
\text { Yes } \\
\text { No }\end{array}$ & $\begin{array}{c}5 \\
152\end{array}$ & $\begin{array}{ll}4 & (1-8) \\
3 & (1-17)\end{array}$ & $\mathrm{U}=533^{\mathrm{b}}$ & $0.57^{\mathrm{b}}$ \\
\hline
\end{tabular}

${ }^{a}$ Corresponds to Mann-Whitney-Wilcoxon test, using the normal approximation

${ }^{b}$ Corresponds to Mann-Whitney-Wilcoxon test, using the $t$ approximation. 
Table 23. Relationships between safety training lessons and hazardous task performance among all trained teens (Full table)

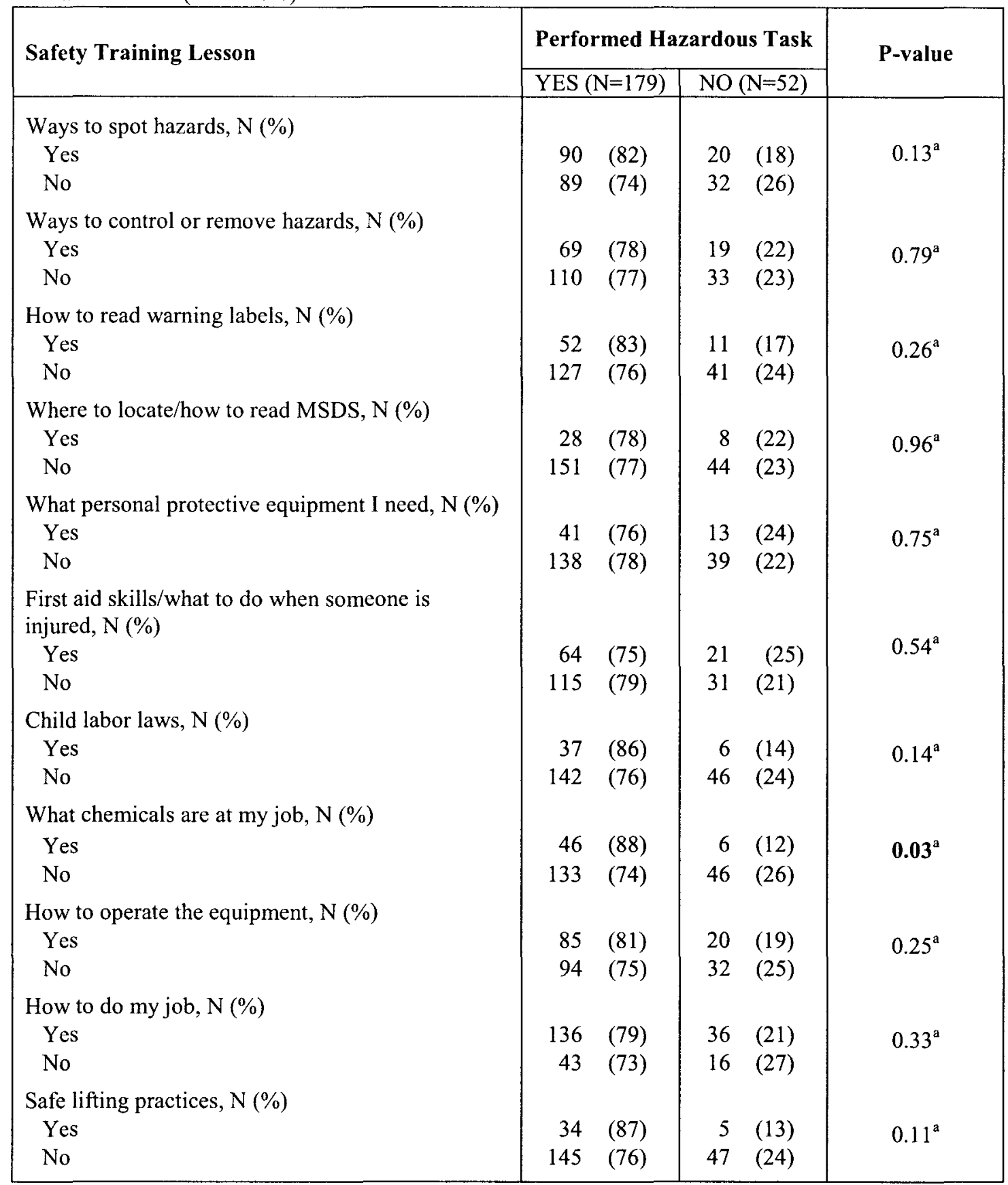

${ }^{a}$ Corresponds to chi-square test

${ }^{\mathrm{b}}$ Corresponds to Fisher's exact test 
Table 23 (Continued). Relationships between safety training lessons and hazardous task performance among all trained teens (Full table)

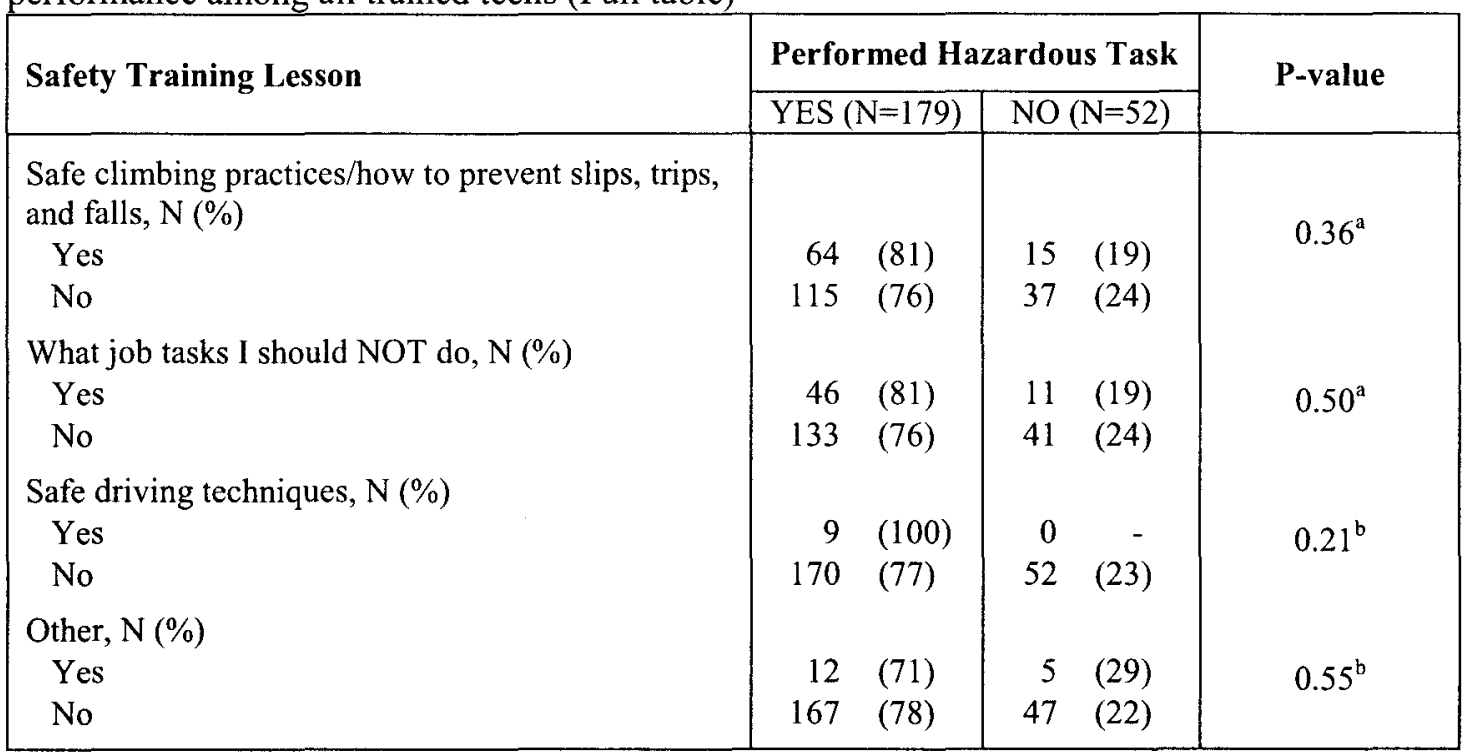

${ }^{a}$ Corresponds to chi-square test

${ }^{b}$ Corresponds to Fisher's exact test 
Table 24. Logistic regression predicting hazardous task performance by the receipt of safety training lessons among all trained teens (Full table)

\begin{tabular}{|c|c|c|c|c|}
\hline Safety Training Lesson & $\begin{array}{l}\text { Crude } \\
\text { Odds } \\
\text { Ratio } \\
\end{array}$ & $\begin{array}{c}95 \% \\
\text { Confidence } \\
\text { Interval } \\
\end{array}$ & $\begin{array}{l}\text { Adjusted Odds } \\
\text { Ratio* }^{*}\end{array}$ & $\begin{array}{c}95 \% \\
\text { Confidence } \\
\text { Interval } \\
\end{array}$ \\
\hline $\begin{array}{l}\text { Ways to spot hazards } \\
\text { Yes } \\
\text { No }\end{array}$ & $\begin{array}{l}1.62 \\
\text { Ref }\end{array}$ & $0.86-3.04$ & $\begin{array}{l}1.84 \\
\operatorname{Ref}\end{array}$ & $0.91-3.73$ \\
\hline $\begin{array}{l}\text { Ways to control or remove hazards } \\
\text { Yes } \\
\text { No }\end{array}$ & $\begin{array}{l}1.09 \\
\text { Ref }\end{array}$ & $0.58-2.07$ & $\begin{array}{l}1.10 \\
\operatorname{Ref}\end{array}$ & $0.54-2.21$ \\
\hline $\begin{array}{l}\text { How to read warning labels } \\
\text { Yes } \\
\text { No }\end{array}$ & $\begin{array}{l}1.53 \\
\operatorname{Ref}\end{array}$ & $0.73-3.20$ & $\begin{array}{l}1.72 \\
\text { Ref }\end{array}$ & $0.76-3.92$ \\
\hline $\begin{array}{l}\text { Where to locate/how to read MSDS } \\
\text { Yes } \\
\text { No }\end{array}$ & $\begin{array}{l}1.02 \\
\text { Ref }\end{array}$ & $0.43-2.40$ & $\begin{array}{l}1.31 \\
\text { Ref }\end{array}$ & $0.51-3.37$ \\
\hline $\begin{array}{l}\text { What personal protective equipment } \\
\text { I need } \\
\text { Yes } \\
\text { No }\end{array}$ & $\begin{array}{l}0.89 \\
\text { Ref }\end{array}$ & $0.44-1.83$ & $\begin{array}{l}1.03 \\
\text { Ref }\end{array}$ & $0.46-2.31$ \\
\hline $\begin{array}{l}\text { First aid skills/what to do when } \\
\text { someone is injured } \\
\text { Yes } \\
\text { No }\end{array}$ & $\begin{array}{l}0.82 \\
\text { Ref }\end{array}$ & $0.44-1.55$ & $\begin{array}{l}0.85 \\
\text { Ref }\end{array}$ & $0.42-1.73$ \\
\hline $\begin{array}{l}\text { Child labor laws } \\
\text { Yes } \\
\text { No }\end{array}$ & $\begin{array}{l}2.00 \\
\text { Ref }\end{array}$ & $0.79-5.04$ & $\begin{array}{l}2.41 \\
\text { Ref }\end{array}$ & $0.87-6.68$ \\
\hline $\begin{array}{l}\text { What chemicals are at my job } \\
\text { Yes } \\
\text { No }\end{array}$ & $\begin{array}{l}2.65 \\
\text { Ref }\end{array}$ & $1.06-6.62$ & $\begin{array}{l}2.93 \\
\operatorname{Ref}\end{array}$ & $1.07-8.01$ \\
\hline $\begin{array}{l}\text { How to operate the equipment } \\
\text { Yes } \\
\text { No }\end{array}$ & $\begin{array}{l}1.45 \\
\operatorname{Ref}\end{array}$ & $0.77-2.72$ & $\begin{array}{l}1.68 \\
\text { Ref }\end{array}$ & $0.82-3.43$ \\
\hline $\begin{array}{l}\text { How to do my job } \\
\text { Yes } \\
\text { No }\end{array}$ & $\begin{array}{l}1.41 \\
\text { Ref }\end{array}$ & $0.71-2.78$ & $\begin{array}{l}1.89 \\
\text { Ref }\end{array}$ & $0.85-4.23$ \\
\hline $\begin{array}{l}\text { Safe lifting practices } \\
\text { Yes } \\
\text { No }\end{array}$ & $\begin{array}{l}2.20 \\
\text { Ref }\end{array}$ & $0.82-5.96$ & $\begin{array}{l}1.89 \\
\operatorname{Ref}\end{array}$ & $0.66-5.40$ \\
\hline
\end{tabular}

${ }^{*}$ Controlled for race, gender, sleep, and communication with parent/guardian 
Table 24 (Continued). Logistic regression predicting hazardous task performance by the receipt of safety training lessons among all trained teens (Full table)

\begin{tabular}{|c|c|c|c|c|}
\hline Safety Training Lesson & $\begin{array}{l}\text { Crude } \\
\text { Odds } \\
\text { Ratio } \\
\end{array}$ & $\begin{array}{c}95 \% \\
\text { Confidence } \\
\text { Interval }\end{array}$ & $\begin{array}{c}\text { Adjusted Odds } \\
\text { Ratio* }\end{array}$ & $\begin{array}{c}95 \% \\
\text { Confidence } \\
\text { Interval } \\
\end{array}$ \\
\hline $\begin{array}{l}\text { Safe climbing practices/how to } \\
\text { prevent slips, trips, and falls, } \\
\text { Yes } \\
\text { No }\end{array}$ & $\begin{array}{l}1.37 \\
\text { Ref }\end{array}$ & $0.7-2.69$ & $\begin{array}{l}1.48 \\
\text { Ref }\end{array}$ & $0.70-3.11$ \\
\hline $\begin{array}{l}\text { What job tasks I should NOT do } \\
\text { Yes } \\
\text { No }\end{array}$ & $\begin{array}{l}1.29 \\
\text { Ref }\end{array}$ & $0.61-2.72$ & $\begin{array}{l}1.27 \\
\text { Ref }\end{array}$ & $0.55-2.91$ \\
\hline $\begin{array}{l}\text { Safe driving techniques } \\
\text { Yes } \\
\text { No }\end{array}$ & $\begin{array}{c}\text { Not } \\
\text { enough } \\
\text { data }\end{array}$ & & & \\
\hline $\begin{array}{c}\text { Other } \\
\text { Yes } \\
\text { No }\end{array}$ & $\begin{array}{l}0.68 \\
\text { Ref }\end{array}$ & $0.23-2.01$ & $\begin{array}{l}0.48 \\
\text { Ref }\end{array}$ & $0.13-1.72$ \\
\hline
\end{tabular}

*Controlled for race, gender, sleep, and communication with parent/guardian 
Table 25. Relationships between safety training lessons and prohibited task performance among all trained teens (Full table)

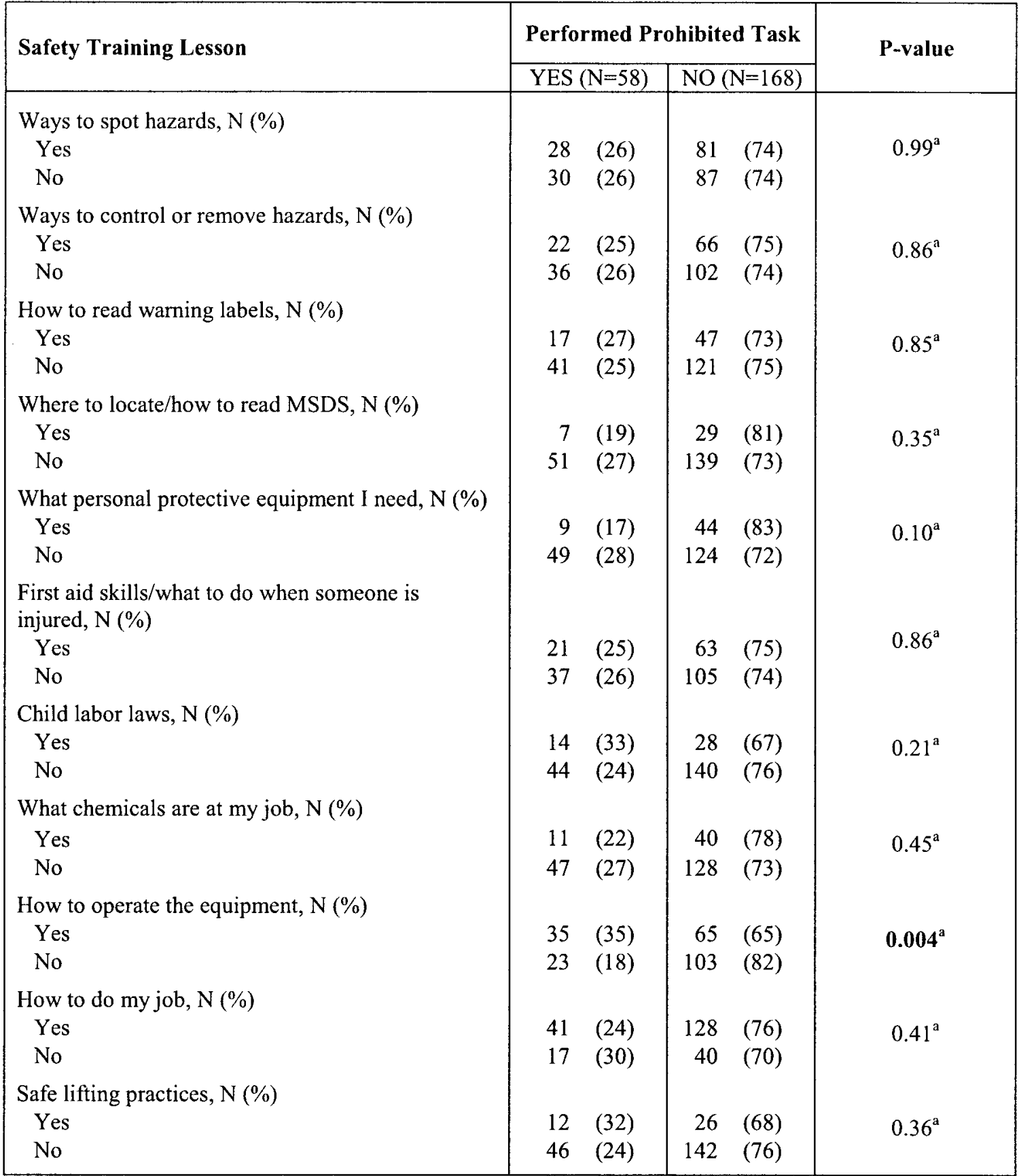

${ }^{a}$ Corresponds to chi-square test

${ }^{b}$ Corresponds to Fisher's exact test 
Table 25 (Continued). Relationships between safety training lessons and prohibited task performance among all trained teens (Full table)

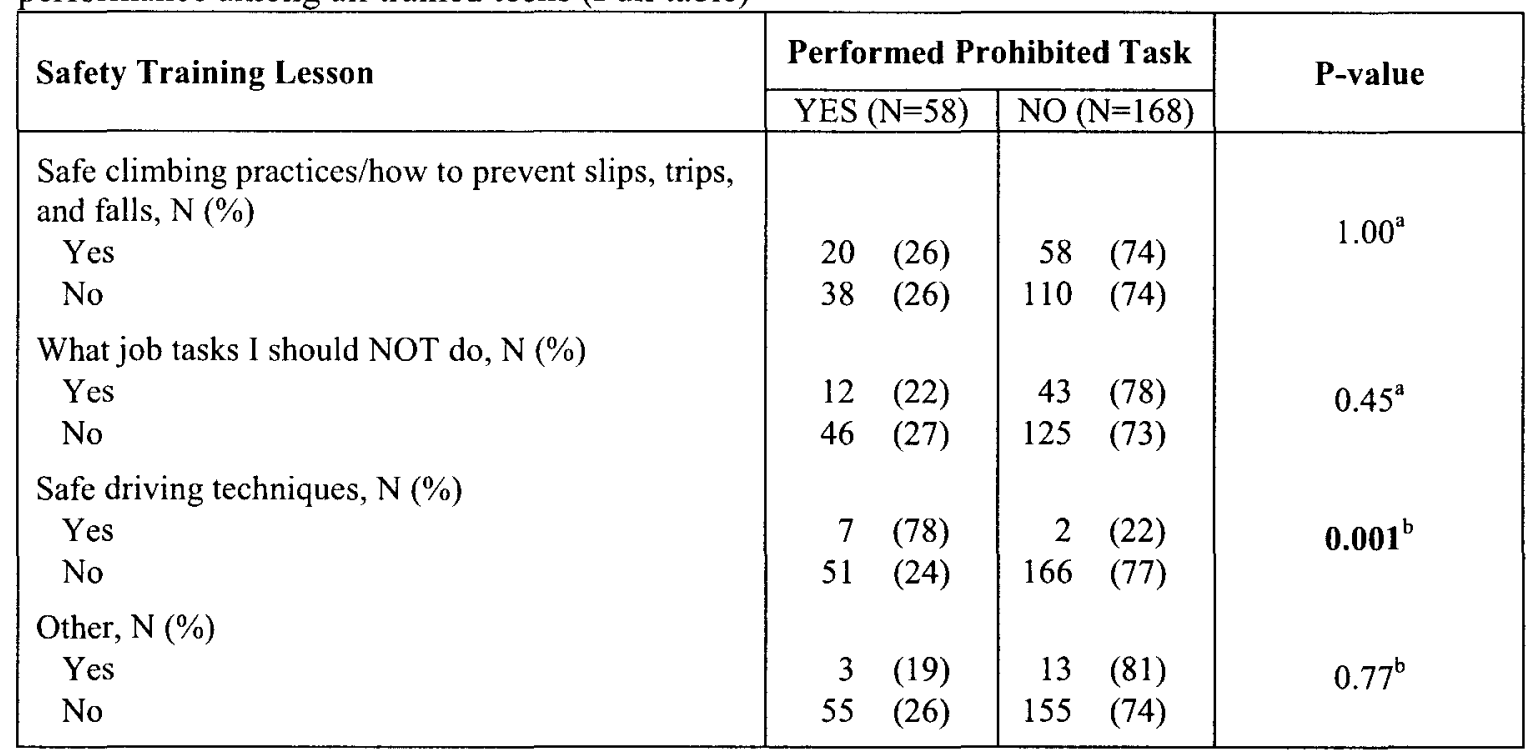

${ }^{a}$ Corresponds to chi-square test

${ }^{\mathrm{b}}$ Corresponds to Fisher's exact test 
Table 26. Logistic regression predicting prohibited task performance by the receipt of safety training lessons among all trained teens (Full table)

\begin{tabular}{|c|c|c|c|c|}
\hline Safety Training Lesson & $\begin{array}{l}\text { Crude } \\
\text { Odds } \\
\text { Ratio } \\
\end{array}$ & $\begin{array}{c}95 \% \\
\text { Confidence } \\
\text { Interval } \\
\end{array}$ & $\begin{array}{c}\text { Adjusted Odds } \\
\text { Ratio }^{*}\end{array}$ & $\begin{array}{c}5 \% \\
\text { Confidence } \\
\text { Interval } \\
\end{array}$ \\
\hline $\begin{array}{l}\text { Ways to spot hazards } \\
\text { Yes } \\
\text { No }\end{array}$ & $\begin{array}{l}1.00 \\
\text { Ref }\end{array}$ & $0.55-1.82$ & $\begin{array}{l}0.93 \\
\operatorname{Ref}\end{array}$ & $0.49-1.77$ \\
\hline $\begin{array}{l}\text { Ways to control or remove hazards } \\
\text { Yes } \\
\text { No }\end{array}$ & $\begin{array}{l}0.94 \\
\text { Ref }\end{array}$ & $0.51-1.75$ & $\begin{array}{l}1.10 \\
\operatorname{Ref}\end{array}$ & $0.57-2.13$ \\
\hline $\begin{array}{l}\text { How to read warning labels } \\
\text { Yes } \\
\text { No }\end{array}$ & $\begin{array}{l}1.07 \\
\text { Ref }\end{array}$ & $0.55-2.06$ & $\begin{array}{l}1.32 \\
\text { Ref }\end{array}$ & $0.65-2.68$ \\
\hline $\begin{array}{l}\text { Where to locate/how to read MSDS } \\
\text { Yes } \\
\text { No }\end{array}$ & $\begin{array}{l}0.66 \\
\text { Ref }\end{array}$ & $0.27-1.60$ & $\begin{array}{l}0.65 \\
\text { Ref }\end{array}$ & $0.24-1.72$ \\
\hline $\begin{array}{l}\text { What personal protective equipment } \\
\text { I need } \\
\text { Yes } \\
\text { No }\end{array}$ & $\begin{array}{l}0.52 \\
\text { Ref }\end{array}$ & $0.24-1.14$ & $\begin{array}{l}0.64 \\
\operatorname{Ref}\end{array}$ & $0.27-1.48$ \\
\hline $\begin{array}{l}\text { First aid skills/what to do when } \\
\text { someone is injured } \\
\text { Yes } \\
\text { No }\end{array}$ & $\begin{array}{l}0.95 \\
\text { Ref }\end{array}$ & $0.51-1.76$ & $\begin{array}{l}1.05 \\
\operatorname{Ref}\end{array}$ & $0.54-2.06$ \\
\hline $\begin{array}{l}\text { Child labor laws } \\
\text { Yes } \\
\text { No }\end{array}$ & $\begin{array}{l}1.59 \\
\text { Ref }\end{array}$ & $0.77-3.29$ & $\begin{array}{l}1.85 \\
\text { Ref }\end{array}$ & $0.84-4.07$ \\
\hline $\begin{array}{l}\text { What chemicals are at my job } \\
\text { Yes } \\
\text { No }\end{array}$ & $\begin{array}{l}0.75 \\
\text { Ref }\end{array}$ & $0.36-1.58$ & $\begin{array}{l}0.90 \\
\operatorname{Ref}\end{array}$ & $0.41-1.98$ \\
\hline $\begin{array}{l}\text { How to operate the equipment } \\
\text { Yes } \\
\text { No }\end{array}$ & $\begin{array}{r}2.41 \\
\text { Ref }\end{array}$ & $1.31-4.44$ & $\begin{array}{l}2.34 \\
\text { Ref }\end{array}$ & $1.22-4.50$ \\
\hline $\begin{array}{l}\text { How to do my job } \\
\text { Yes } \\
\text { No }\end{array}$ & $\begin{array}{l}0.75 \\
\text { Ref }\end{array}$ & $0.39-1.47$ & $\begin{array}{l}0.98 \\
\text { Ref }\end{array}$ & $0.47-2.04$ \\
\hline $\begin{array}{l}\text { Safe lifting practices } \\
\text { Yes } \\
\text { No }\end{array}$ & $\begin{array}{l}1.43 \\
\operatorname{Ref}\end{array}$ & $0.67-3.05$ & $\begin{array}{l}1.45 \\
\operatorname{Ref}\end{array}$ & $0.65-3.27$ \\
\hline
\end{tabular}

*Controlled for race, gender, communication with parent/guardian and the feeling that their supervisor makes sure they understand workplace safety. 
Table 26 (Continued). Logistic regression predicting prohibited task performance by the receipt of safety training lessons among all trained teens (Full table)

\begin{tabular}{|c|c|c|c|c|}
\hline Safety Training Lesson & $\begin{array}{c}\text { Crude } \\
\text { Odds } \\
\text { Ratio } \\
\end{array}$ & $\begin{array}{c}95 \% \\
\text { Confidence } \\
\text { Interval } \\
\end{array}$ & $\begin{array}{c}\text { Adjusted Odds } \\
\text { Ratio }^{*}\end{array}$ & $\begin{array}{c}95 \% \\
\text { Confidence } \\
\text { Interval } \\
\end{array}$ \\
\hline $\begin{array}{l}\text { Safe climbing practices/how to } \\
\text { prevent slips, trips, and falls, } \\
\text { Yes } \\
\text { No }\end{array}$ & $\begin{array}{l}1.00 \\
\text { Ref }\end{array}$ & $0.53-1.87$ & $\begin{array}{l}1.06 \\
\operatorname{Ref}\end{array}$ & $0.53-2.12$ \\
\hline $\begin{array}{l}\text { What job tasks I should NOT do } \\
\text { Yes } \\
\text { No }\end{array}$ & $\begin{array}{l}0.76 \\
\text { Ref }\end{array}$ & $0.37-1.56$ & $\begin{array}{l}0.73 \\
\text { Ref }\end{array}$ & $0.33-1.58$ \\
\hline $\begin{array}{l}\text { Safe driving techniques } \\
\text { Yes } \\
\text { No }\end{array}$ & $\begin{array}{c}11.39 \\
\text { Ref }\end{array}$ & $2.29-56.57$ & $\begin{array}{c}10.70 \\
\operatorname{Ref}\end{array}$ & $2.05-55.96$ \\
\hline $\begin{array}{c}\text { Other } \\
\text { Yes } \\
\text { No }\end{array}$ & $\begin{array}{l}0.65 \\
\text { Ref }\end{array}$ & $0.18-2.37$ & $\begin{array}{l}0.54 \\
\text { Ref }\end{array}$ & $0.14-2.10$ \\
\hline
\end{tabular}

${ }^{*}$ Controlled for race, gender, communication with parent/guardian and the feeling that their supervisor makes sure they understand workplace safety. 
Table 27. Relationships between safety training lessons and dangerous task performance among all trained teens (Full table)

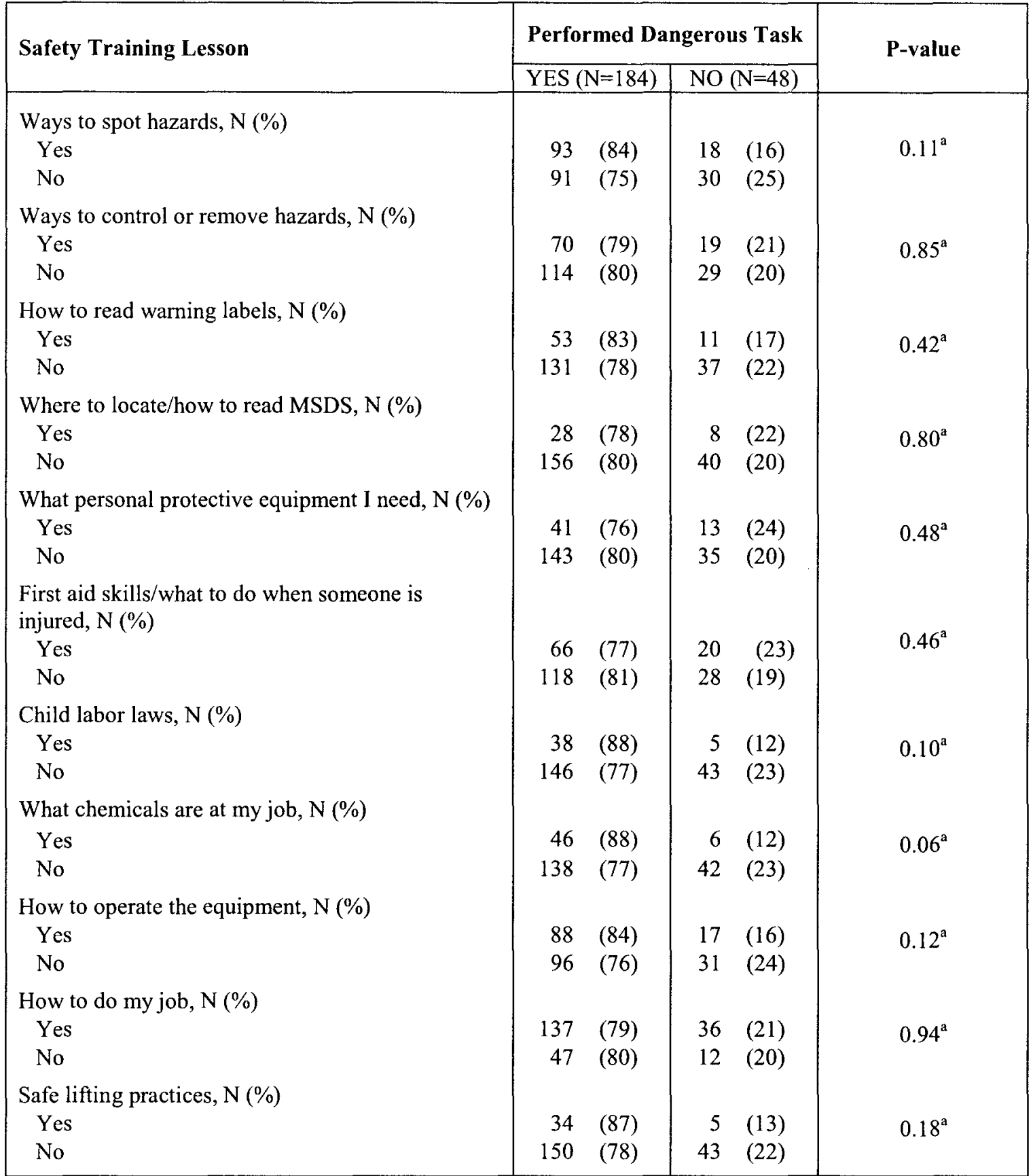

${ }^{a}$ Corresponds to chi-square test

${ }^{b}$ Corresponds to Fisher's exact test 
Table 27 (Continued). Relationships between safety training lessons and dangerous task performance among all trained teens (Full table)

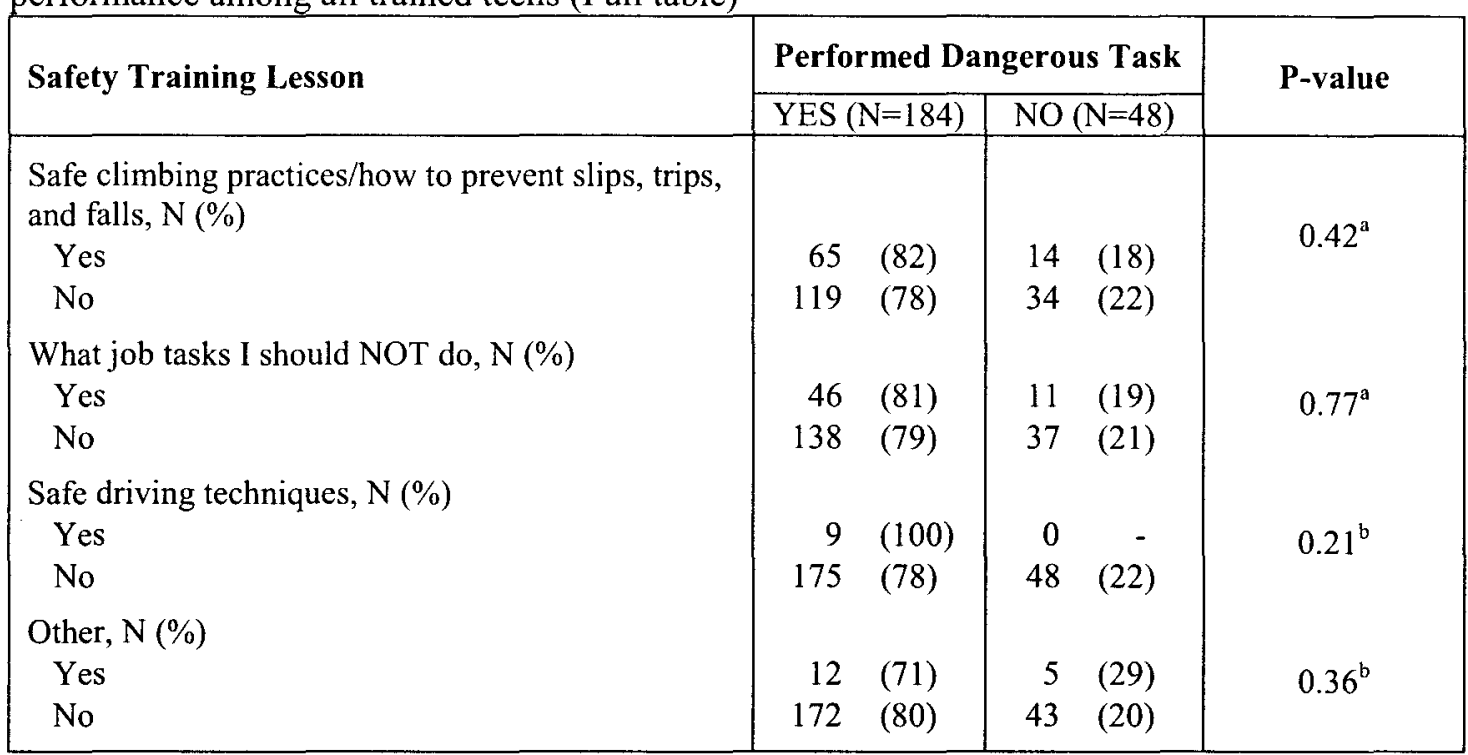

${ }^{\mathrm{a}}$ Corresponds to chi-square test

${ }^{\mathrm{b}}$ Corresponds to Fisher's exact test 
Table 28. Logistic regression predicting dangerous task performance by the receipt of safety training lessons among all trained teens (Full table)

\begin{tabular}{|c|c|c|c|c|}
\hline Safety Training Lesson & $\begin{array}{l}\text { Crude } \\
\text { Odds } \\
\text { Ratio } \\
\end{array}$ & $\begin{array}{c}95 \% \\
\text { Confidence } \\
\text { Interval } \\
\end{array}$ & $\begin{array}{c}\text { Adjusted Odds } \\
\text { Ratio* }\end{array}$ & $\begin{array}{c}95 \% \\
\text { Confidence } \\
\text { Interval } \\
\end{array}$ \\
\hline $\begin{array}{l}\text { Ways to spot hazards } \\
\text { Yes } \\
\text { No }\end{array}$ & $\begin{array}{l}1.70 \\
\text { Ref }\end{array}$ & $0.89-3.27$ & $\begin{array}{l}1.67 \\
\text { Ref }\end{array}$ & $0.82-3.38$ \\
\hline $\begin{array}{l}\text { Ways to control or remove hazards } \\
\text { Yes } \\
\text { No }\end{array}$ & $\begin{array}{l}0.94 \\
\text { Ref }\end{array}$ & $0.49-1.80$ & $\begin{array}{l}1.01 \\
\text { Ref }\end{array}$ & $0.50-2.05$ \\
\hline $\begin{array}{l}\text { How to read warning labels } \\
\text { Yes } \\
\text { No }\end{array}$ & $\begin{array}{l}1.36 \\
\text { Ref }\end{array}$ & $0.65-2.87$ & $\begin{array}{l}1.65 \\
\text { Ref }\end{array}$ & $0.73-3.73$ \\
\hline $\begin{array}{l}\text { Where to locate/how to read MSDS } \\
\text { Yes } \\
\text { No }\end{array}$ & $\begin{array}{l}0.90 \\
\text { Ref }\end{array}$ & $0.38-2.12$ & $\begin{array}{l}1.12 \\
\text { Ref }\end{array}$ & $0.44-2.85$ \\
\hline $\begin{array}{l}\text { What personal protective equipment } \\
\text { I need } \\
\text { Yes } \\
\text { No }\end{array}$ & $\begin{array}{l}0.77 \\
\text { Ref }\end{array}$ & $0.37-1.59$ & $\begin{array}{l}0.91 \\
\text { Ref }\end{array}$ & $0.41-2.03$ \\
\hline $\begin{array}{l}\text { First aid skills/what to do when } \\
\text { someone is injured } \\
\text { Yes } \\
\text { No }\end{array}$ & $\begin{array}{l}0.78 \\
\text { Ref }\end{array}$ & $0.41-1.50$ & $\begin{array}{l}0.88 \\
\text { Ref }\end{array}$ & $0.43-1.81$ \\
\hline $\begin{array}{l}\text { Child labor laws } \\
\text { Yes } \\
\text { No }\end{array}$ & $\begin{array}{l}2.24 \\
\text { Ref }\end{array}$ & $0.83-6.04$ & $\begin{array}{l}2.83 \\
\text { Ref }\end{array}$ & $0.96-8.30$ \\
\hline $\begin{array}{l}\text { What chemicals are at my job } \\
\text { Yes } \\
\text { No }\end{array}$ & $\begin{array}{l}2.33 \\
\text { Ref }\end{array}$ & $0.93-5.84$ & $\begin{array}{l}2.63 \\
\text { Ref }\end{array}$ & $0.97-7.14$ \\
\hline $\begin{array}{l}\text { How to operate the equipment } \\
\text { Yes } \\
\text { No }\end{array}$ & $\begin{array}{l}1.67 \\
\text { Ref }\end{array}$ & $0.87-3.23$ & $\begin{array}{l}1.69 \\
\text { Ref }\end{array}$ & $0.82-3.48$ \\
\hline $\begin{array}{l}\text { How to do my job } \\
\text { Yes } \\
\text { No }\end{array}$ & $\begin{array}{l}0.97 \\
\text { Ref }\end{array}$ & $0.47-2.02$ & $\begin{array}{l}1.50 \\
\text { Ref }\end{array}$ & $0.66-3.39$ \\
\hline $\begin{array}{l}\text { Safe lifting practices } \\
\text { Yes } \\
\text { No }\end{array}$ & $\begin{array}{l}1.95 \\
\text { Ref }\end{array}$ & $0.72-5.29$ & $\begin{array}{l}1.73 \\
\text { Ref }\end{array}$ & $0.61-4.94$ \\
\hline
\end{tabular}

${ }^{*}$ Controlled for race, gender, sleep, and communication with parent/guardian 
Table 28 (Continued). Logistic regression predicting dangerous task performance by the receipt of safety training lessons among all trained teens (Full table)

\begin{tabular}{|l|c|c|c|c|}
\hline Safety Training Lesson & $\begin{array}{c}\text { Crude } \\
\text { Odds } \\
\text { Ratio }\end{array}$ & $\begin{array}{c}\mathbf{9 5 \%} \\
\text { Confidence } \\
\text { Interval }\end{array}$ & $\begin{array}{c}\text { Adjusted Odds } \\
\text { Ratio* }\end{array}$ & $\begin{array}{c}\mathbf{9 5 \%} \\
\text { Confidence } \\
\text { Interval }\end{array}$ \\
\hline $\begin{array}{l}\text { Safe climbing practices/how to } \\
\text { prevent slips, trips, and falls }\end{array}$ & 1.33 & $0.66-2.65$ & 1.47 & \\
Yes & Ref & & & $0.69-3.12$ \\
No & 1.12 & $0.53-2.38$ & 1.10 & $0.48-2.52$ \\
What job tasks I should NOT do & Ref & & Ref & \\
Yes & Not & & & \\
No & enough & & & \\
Safe driving techniques & data & & 0.48 & $0.13-1.70$ \\
Yes & Ref & \\
No & 0.60 & $0.20-1.79$ & & \\
Other & Ref & & & \\
Yes & & & & \\
No & & & & \\
\hline
\end{tabular}

${ }^{*}$ Controlled for race, gender, sleep, and communication with parent/guardian 
Table 29. Differences in dangerous task scores between recipients of lessons of safety training, among all trained teens who performed dangerous tasks (Full table)

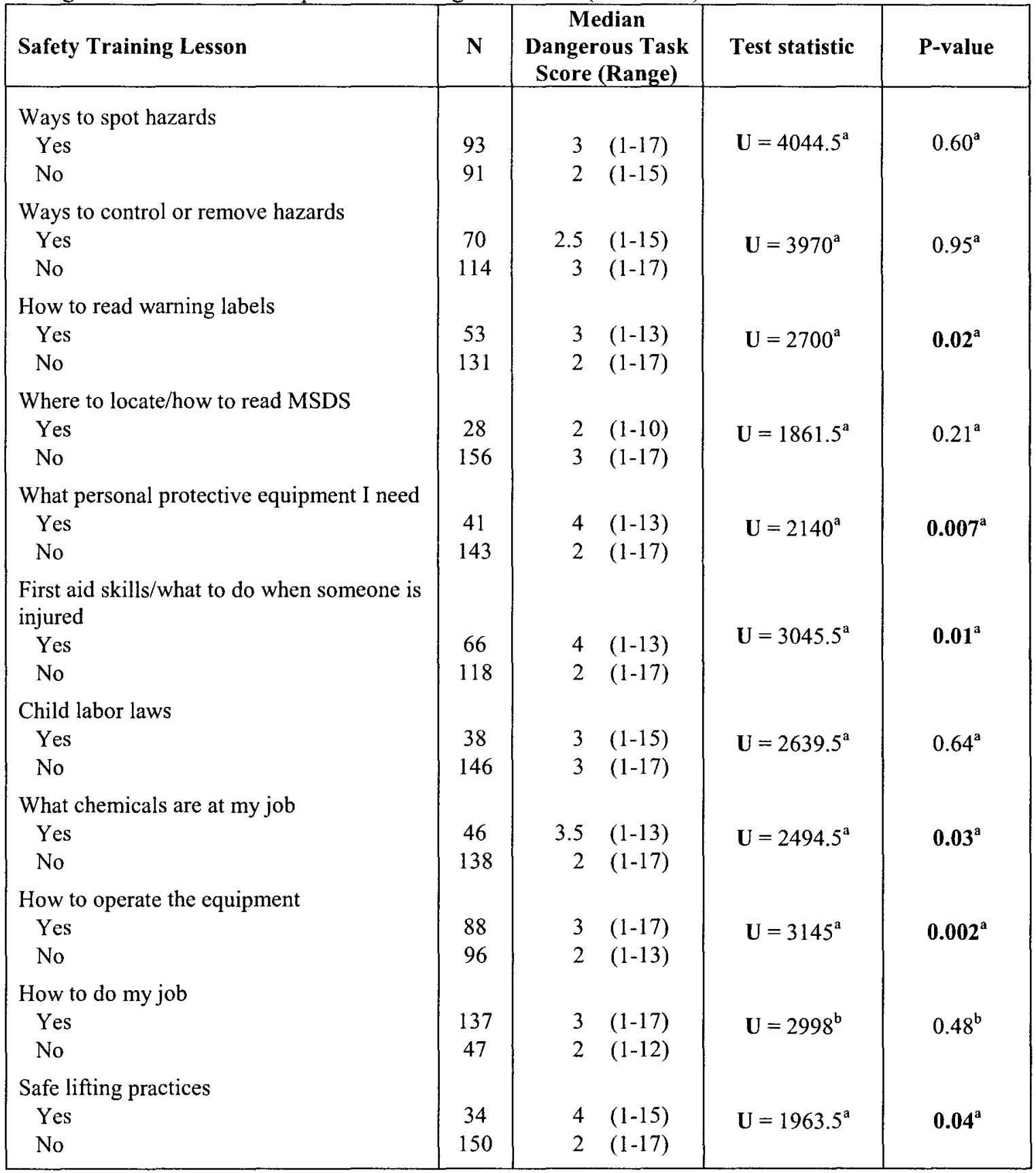

${ }^{a}$ Corresponds to Mann-Whitney-Wilcoxon test, using the normal approximation

${ }^{b}$ Corresponds to Mann-Whitney-Wilcoxon test, using the $t$ approximation. 
Table 29 (Continued). Differences in dangerous task scores between recipients of lessons of safety training, among all trained teens who performed dangerous tasks (Full table)

\begin{tabular}{|c|c|c|c|c|}
\hline Safety Training Lesson & $\mathbf{N}$ & $\begin{array}{c}\text { Median } \\
\text { Dangerous Task } \\
\text { Score (Range) } \\
\end{array}$ & Test statistic & P-value \\
\hline $\begin{array}{l}\text { Safe climbing practices/how to prevent } \\
\text { slips, trips, and falls, } \\
\text { Yes } \\
\text { No }\end{array}$ & $\begin{array}{c}65 \\
119\end{array}$ & $\begin{array}{ll}3 & (1-15) \\
2 & (1-17)\end{array}$ & $\mathbf{U}=3212.5^{\mathbf{a}}$ & $0.054^{\mathrm{a}}$ \\
\hline $\begin{array}{l}\text { What job tasks I should NOT do } \\
\text { Yes } \\
\text { No }\end{array}$ & $\begin{array}{c}46 \\
138\end{array}$ & $\begin{array}{ll}4 & (1-11) \\
2 & (1-17)\end{array}$ & $\mathrm{U}=2354.5^{\mathrm{a}}$ & $0.008^{\mathrm{a}}$ \\
\hline $\begin{array}{l}\text { Safe driving techniques } \\
\text { Yes } \\
\text { No }\end{array}$ & $\begin{array}{c}9 \\
175\end{array}$ & $\begin{array}{ll}4 & (2-10) \\
2 & (1-17)\end{array}$ & $\mathrm{U}=495.5^{\mathrm{b}}$ & $0.059^{\mathrm{b}}$ \\
\hline $\begin{array}{l}\text { Other } \\
\text { Yes } \\
\text { No }\end{array}$ & $\begin{array}{c}12 \\
172\end{array}$ & $\begin{array}{ll}2 & (1-8) \\
3 & (1-17)\end{array}$ & $\mathrm{U}=926^{\mathrm{b}}$ & $0.55^{\mathrm{b}}$ \\
\hline
\end{tabular}

${ }^{a}$ Corresponds to Mann-Whitney-Wilcoxon test, using the normal approximation

${ }^{\mathrm{b}}$ Corresponds to Mann-Whitney-Wilcoxon test, using the $t$ approximation 


\section{CURRICULUM VITAE}

July 2012

TERESA JANE MCGEENEY

\section{PERSONAL}

Birthdate:

Address:

Email address:
19 October 1987

Department of Epidemiology \& Population Health School of Public Health \& Information Sciences University of Louisville 485 East Gray Street Louisville, KY 40202

tjmcge01@louisville.edu

\section{EDUCATION}

BA Pre-professional Studies University of Notre Dame, Notre Dame, IN (2009) Arabic

MS Epidemiology University of Louisville, Louisville, KY (2012 exp)

PROFESSIONAL EXPERIENCE

Graduate Research Assistant, Department of Epidemiology and Population Health, School of Public Health and Information Sciences, University of Louisville, Louisville, Kentucky, June 2010 - December 2011

HONORS AND AWARDS

Dean's List, University of Notre Dame, Fall 2006, Fall 2008

PROFESSIONAL AFFILIATIONS

$2011-2012$

American Public Health Association 


\section{PUBLISHED MANUSCRIPTS}

Zierold KM, Welsh EC, McGeeney TJ. Attitudes of teenagers towards workplace safety training. $J$ Community Health. 2012 May 22 [Epub ahead of print].

\section{POSTER PRESENTATIONS}

McGeeney TJ, Welsh EC, Zierold KM. Injury severity among working teenagers as related to safety training. Poster presentation, American Public Health Association $139^{\text {th }}$ Annual Meeting and Exposition, Washington, D.C., October/November 2011.

McGeeney TJ, Welsh EC, Zierold KM. Quality of supervision and injury among teenagers in the workplace. Poster presentation, American Public Health Association $139^{\text {th }}$ Annual Meeting and Exposition, Washington, D.C., October/November 2011.

McGeeney TJ, Welsh EC, Zierold KM. Gender disparities in risk-taking tendencies and workplace injury among teenagers. First national conference on Eliminating Health and Safety Disparities at Work, Chicago, IL, September 2011.

McGeeney TJ, Zierold KM. Supervision in the workplace: Shaping teenagers' perception of safety and reporting of injury. Poster presentation, Research!Louisville, Louisville, KY, October 2010.

\section{COLLABORATIVE POSTER/ORAL PRESENTATIONS}

Welsh EC, McGeeney TJ, Zierold KM. Healthy communication between parents and working teens and its influence on work-related injury. Oral presentation, American Public Health Association $139^{\text {th }}$ Annual Meeting and Exposition, Washington, D.C., October/November 2011.

Welsh EC, McGeeney TJ, Zierold KM. Use of dangerous equipment in the workplace and safety training: Effects on work-related injury in teenagers. Poster presentation, American Public Health Association $139^{\text {th }}$ Annual Meeting and Exposition, Washington, D.C., October/November 2011.

Welsh EC, McGeeney TJ, Zierold KM. Knowledge of US child labor laws and influence on work-related injury among working teenagers. Poster presentation, American Public Health Association $139^{\text {th }}$ Annual Meeting and Exposition, Washington, D.C., October/November 2011.

Welsh EC, McGeeney TJ, Zierold KM. Evaluation of safety training for teenagers in regards to dangerous situation response for injury prevention. Poster presentation, American Public Health Association $139^{\text {th }}$ Annual Meeting and Exposition, Washington, D.C., October/November 2011. 
Welsh EC, McGeeney TJ, Zierold KM. Racial Differences in Supervision Among Teens at Work. . First national conference on Eliminating Health and Safety Disparities at Work, Chicago, IL, September 2011.

Zierold KM, McGeeney $\mathbf{T J}$. The role of safety training in preventing workplace injuries in teenagers. Poster presentation, $11^{\text {th }}$ Annual American Academy of Health Behavior Meeting, Hilton Head Island, SC, March 2011. 